\author{
UNIVERSidADE DE SÃo PaUlo \\ Faculdade de Medicina de Ribeirão Preto \\ Departamento de GenÉtica
}

\title{
“AVALIAÇÃO dA EXPRESSÃO dE GENES PROCESSADORES DE DANOS OXIDATIVOS EM PACIENTES COM ALZHEIMER"
}

Dissertação apresentada à Faculdade de Medicina de Ribeirão Preto, da Universidade de São Paulo, para a obtenção de título de Mestre em Ciências, área de concentração Genética.

Pós-graduando: Douglas Vinicius Nogueira Perez de Oliveira Orientador: Prof ${ }^{\mathrm{a}}$ Dra Elza Tiemi Sakamoto-Hojo 
Ficha catalográfica

\section{OLIVEIRA, Douglas V. N. P. de}

"AVALIAÇÃO DA EXPRESSÃO DOS GENES PROCESSADORES DE DANOS OXIDATIVOS EM PACIENTES ALZHEIMER"

Ribeirão Preto, 2007

73 p. il. $30 \mathrm{~cm}$

Dissertação de mestrado apresentada à Faculdade de Medicina de Ribeirão Preto, USP, departamento de Genética.

Orientador: Prof $^{a}$ Dr$^{-a}$ Elza Tiemi Sakamoto-Hojo 
Apoio e suporte financeiro

Este trabalho foi realizado com o apoio financeiro das seguintes entidades e instituições:

- Fundação de Amparo à Pesquisa do Estado de São Paulo - FAPESP (Proc ํo 06/1947-8);

- Conselho Nacional de Desenvolvimento Científico e Tecnológico - CNPq;

- Coordenação de Aperfeiçoamento de Pessoal de Nível Superior - CAPES;

- Fundação de Apoio ao Ensino, Pesquisa e Assistência - FAEPA - FMRP/USP;

- Faculdade de Medicina de Ribeirão Preto (FMRP/USP); e

- Faculdade de Filosofia, Ciências e Letras de Ribeirão Preto (FFCLRP/USP). 


\section{AgRADECIMENTOS}

À minha orientadora, Prof ${ }^{\text {a }}$ Dra Elza Tiemi Sakamoto Hojo, por ter me acolhido muito bem em seu laboratório e, principalmente, por me oferecer nesses anos de convívio mais do que orientação. Pelo carinho, amizade e respeito.

À Prof ${ }^{a}$ Dra Catarina Satie Takahashi pelo apoio constante e pela convivência prazerosa que me proporcionou. Exemplo de competência e dedicação à Biologia.

Ao Prof. Dr. Geraldo Aleixo S. Passos Junior, por permitir a utilização dos equipamentos de seu laboratório e pela confiança depositada em mim.

Ao Prof. Dr. Julio C. Moriguti, pela parceria e esclarecimentos neste trabalho, além de permitir a realização das coletas das pacientes em seu ambulatório.

Ao Prof. Dr. Eduardo Ferriolli, por permitir a coleta das amostras das pacientes no ambulatório de Geriatria do HC-FMRP/USP.

Ao Prof. Dr. Charlys Nogueira Barbosa, pela atenção, paciência e companheirinho dispensados a mim durante todo o trabalho. Muito obrigado pelo apoio e ensinamentos valiosos.

Aos enfermeiros do ambulatório da Clínica Médica do HC-FMRP/USP, por coletarem as amostras, em especial, Maria Luiza e Edson.

Aos médicos da Clínica Médica que permitiram a realização das coletas, especialmente, o Dr. Silvio, a Dr. Patrícia e Dr. Raquel, além dos médicos residentes.

Ao Dr. João Manoel, pela atenção e respeito com que me tratou durante o nosso período de convivência. Além da participação ativa do trabalho, fornecendo gentilmente algumas amostras de pacientes. Muito obrigado, Dr João.

Às enfermeiras do ambulatório de geriatria do Sistema Único de Saúde de Ribeirão Preto, unidade Campos Elíseos, pelo tempo e apoio dispensados, além da competência.

À Prof ${ }^{a}$ - Dra Nilce Maria Martinez Rossi, chefe do departamento de Genética da FMRP/USP, e ao Prof. Dr. Moacyr Antonio Mestriner, ex-chefe do departamento, pela atenção e apoio.

Ao Prof. Dr. Ademilson Espencer E. Soares, coordenador do curso de pós-graduação do departamento de Genética da FMRP-USP e à Prof ${ }^{\text {a }}$ Dra ${ }^{a}$ Lucia Regina Martelli, excoordenador, pela preocupação e suporte.

Às funcionárias do departamento, Susie Adriana Nalon, Maria Aparecida Elias e Cleusa Mazzucatto (ex-secretária), pela prestatividade e atenção.

Aos pós-doutorandos Stephano Spanó Mello e Cristina M. Junta pelo apoio técnico e prestatividade.

À pós-doutoranda Dra Ana Lucia Fachin, a qual me apresentou a este laboratório. 
Aos professores membros da banca examinadora, pela disponibilidade e contribuição com críticas e sugestões.

Aos colegas do Laboratório de Imunogenética Molecular, pelo carinho atenção e disponibilidade em todos os momentos que precisei.

Aos técnicos deste laboratório, Sueli Aparecida Neves e Luiz Augusto da Costa Junior, por toda a assistência prestada e também por me ensinarem bastante desde 0 princípio.

Ao pessoal do Laboratório de Citogenética e Mutagênese Ambiental. Aos que já foram Cássia e Cleide, Clara, Ana Lúcia, Carmen, Sol, Marjori, Gilmara, Carla, Luciana, Stephano, Marcelo, Renato e Gustavo -, mas que tive a imensa felicidade em conhecer; e aos que ficam - Ana Claudia, Giovana, Ana Paula, Raquel, Patrícia, Monica, Aline, Juliana, Flávia, Daily, Danilo Jordão, Paulo, Igor, Danillo Espósito, Cristiano, Leonardo, Gustavo e Vinicius. Todos, sem exceção, contribuíram para a realização deste trabalho e, da melhor forma, com carinho e amizade. Tive a sorte em conhecer uma galera tão bacana e por isso, sou muito grato a todos vocês.

Aos meus grandes companheiros desde o começo, Igor, Xitão, Cop e Bollor - grandes figuras, os quais tenho a imensa gratidão por todo esse tempo de convívio. Parceiros para futebol, cinema, viagem e discussões inúteis.

À Raquel, pelos toques e força nas análises e pelas conversas. À Gi, pela companhia a qualquer hora e pelos papos que sempre tínhamos e que, ainda, tive o prazer de ser vizinho.

À Ana Paula e Daniel, pela amizade e pelas ótimas festas - ótimos anfitriões. Aliás, festa lembra churrasco, o que lembra Cristiano, além de um biólogo-filósofo gente boa.

À Patrícia, a mais nova casada do laboratório, pelo carinho e amizade. À Monica, pessoa ponta firme que topa todas. À Juliana e a Flávia pela ajuda na análise do microarranjos e pela simpatia.

Ao Polvilho, Leonardo e Vinicius, pela companhia e bons momentos.

À Adriana e Dona Lucia, por zelarem pela limpeza do laboratório, além da simpatia.

Aos meus primos Junior, Bruno e Eric, os meus grandes amigos também.

Aos meus amigos incondicionais, Claudia, José, Fábio, Marcelo e Larissa.

Agradeço a Ana Claudia, pelo carinho, companheirismo e cumplicidade nesse tempo de ótimo convívio. Se tornou, antes de tudo, uma excelente amiga.

E agradeço e dedico este trabalho aos meus pais, por estarem sempre presentes na minha vida e por não medirem esforços para a nossa felicidade. São os meus referências de vida. Às minhas irmãs, Milena e Alessandra, a quem muito devo também, e pela convivência maravilhosa e pelo amor com que me tratam. E ao Bruno e Klebson. 
ÍNDICE

Resumo

ABstract

ii

INTRODUÇÃo

Dano oxidativo e reparo do DNA

Doença de Alzheimer

Objetivos

Objetivo geral

Objetivos específicos

MATERIAL e MÉtodos

Seleção de pacientes com a doença de Alzheimer

Coleta das amostras de sangue e cultura de linfócitos

Ensaio do Cometa e tratamento com enzima para a detecção de dano oxidativo no DNA

RT-PCR e PCR em tempo real

Microarranjos de cDNA

Forma de análise dos dados

Resultados

Análise de danos no DNA pelo ensaio do Cometa

Expressão gênica por qRT-PCR em Tempo Real

Perfis de expressão gênica por microarranjos de cDNA

Discussão

CONCLUSÃo

REFERÊNCIAS BIBLIOGRÁFICAS 


\section{RESUMO}

Uma parcela significativa das lesões na molécula do DNA é causada por espécies reativas de oxigênio e a sua produção excessiva e/ou o funcionamento deficiente dos sistemas celulares antioxidantes, que neutralizam a sua ação, é conhecido como estresse oxidativo. Os danos em células normais são prontamente detectados por um sistema de defesa e, em conseqüência, uma rede intrínseca de sinalizações é ativada, sendo que uma das vias resulta na ativação dos mecanismos de reparo do DNA. O reparo por excisão de bases (BER) parece ser a via preferencial de reparo de bases oxidadas, mas existem outras vias de reparo implicadas na reversão do dano oxidativo.

A doença de Alzheimer (DA), uma patologia causada particularmente por danos oxidativos, acomete atualmente cerca de 25 milhões de pessoas no mundo, sendo o risco aumentado a partir dos 65 anos de idade. Com isso, a necessidade da identificação de fatores de risco, além de fatores protetores relacionados à DA, tornou-se de grande importância. Por outro lado, há também a necessidade de estudos em nível molecular, que possam fornecer informações sobre os mecanismos que levam ao desenvolvimento da doença.

Nesse sentido, foi realizado no presente trabalho, um estudo de expressão gênica transcricional pelo método de microarranjos de DNA, bem como uma análise por PCR em tempo real para uma série de genes envolvidos na resposta ao dano oxidativo no DNA (percepção de danos e reparo do dano), além de outros genes relacionados à doença. Adicionalmente, foram também avaliadas as quebras na fita dupla de DNA causadas por bases oxidadas, em linfócitos de pacientes de Alzheimer (grau moderado) e indivíduos sadios, usando-se métodos de detecção de bases oxidadas (8-oxoGuanina).

Entre os vinte genes analisados pelo método de PCR quantitativa em tempo real, apenas a APOE mostrou-se induzida, enquanto 19 genes (ADAM17, APEX1, APP, BACE1, OGG1 ATM, ATR, TREX1, FEN1, FANCG, RAD17, DUSP, ERCC1, ERCC3, ERCC6, HUS1, $R A D 9, R A D 1, P R K D C$ ) foram reprimidos transcricionalmente. Essa repressão verificada para a maior parte dos genes estudados indica que várias vias de sinalização celular ligadas a respostas ao estresse oxidativo, incluindo-se as várias vias de reparo do DNA, podem estar envolvidas na condição DA.

Adicionalmente, a análise de expressão gênica por microarranjos de cDNA indicou uma série de 41 genes significativamente modulados $(q<0,06)$ (dentre eles, NOTCH1, MARK3, $P A K, S M C 1 L 1)$ mas para a maioria destes não há relatos na literatura sobre uma possível relação com DA. Por essa razão, o método de microarranjos de cDNA aponta novas vias que possam estar alteradas em DA, o que constitui uma informação importante. Em conjunto, os dados obtidos no presente estudo fornecem uma contribuição relevante, que futuramente poderão contribuir em termos de intervenção terapêutica. 


\section{ABStRact}

A great amount of DNA molecule lesions is caused by reactive oxygen species and its synthesis in excess and/or misfunctioning of antioxidant cell systems, which neutralize its effects, is known as oxidative stress. Damage in normal cells is readily detected by a defence system and as consequence, a complex signaling pathway is activated, among them DNA repair mechanisms. The base excision repair $(B E R)$ seems to be the primary repair pathway in base oxidative damages, however there are other pathways that are involved in their repair.

The Alzheimer's disease (AD), a pathology caused particularly by oxidative damages, hits 25 million people worldwide, and its prevalence increases every 5 years beyond age 65 . Therefore, there is an emerging need of finding risk factors, as well as protective factors related do AD. By the other hand, it is also necessary molecular studies, which could provide precious information about the mechanisms which lead to the disease development.

In the present work, it was made a study about transcriptional gene expression by cDNA microarray, as well as Real Time PCR analysis in a series of genes involved in oxidative DNA damage response (sensing and damage repair), and others associated with the disease. In addition, it were also evaluated DNA strand breaks induced by oxidized bases in lymphocytes from Alzheimer's patients (moderate level) and healthy individuals, by oxidized bases (8oxoguanine) detection methods.

Among the twenty genes tested by the quantitative Real Time PCR assay, only APOE was induced, as the remaining 19 (ADAM17, APEX1, APP, BACE1, OGG1 ATM, ATR, TREX1, FEN1, FANCG, RAD17, DUSP, ERCC1, ERCC3, ERCC6, HUS1, RAD9, RAD1, PRKDC) were found repressed. This observed inhibition in most of genes studied shows that many cell signaling pathways associated to oxidative stress response, including DNA repair pathways, may be also involved in the AD pathology.

Additionally, the gene expression analysis by cDNA microarrays showed transcriptional alterations in 41 genes $(q<0.06)$ (among them, NOTCH1, MARK3, PAK and SMC1L1), but for most of them, there are no reports in the literature about their possible relationship with AD, what brought us new important information. Together, all the data obtained in the preset study provide a relevant contribution, which, in the future, may help on new therapeutic designs. 


\section{INTRODUÇÃO}

\section{Dano oxidativo e reparo do DNA}

As células procarióticas ou eucarióticas são continuamente expostas a agentes endógenos e exógenos que danificam o DNA. Os vários tipos de lesões no DNA que resultam dessas exposições são rapidamente detectados, com a subseqüente ativação de uma rede intrínseca de sinalizações, conhecida como resposta ao dano. Essa resposta leva à ativação de checkpoints do ciclo celular e às vias competentes de reparo do DNA, ou em certas circunstâncias, ao início do processo apoptótico. A resposta ao dano no DNA é um processo coordenado, o qual é executado através de uma série de passos. As lesões são detectadas por proteínas sensoras e, então, os transdutores são ativados para mediar o sinal de dano às proteínas efetoras - durante essas etapas ocorre a modulação de várias vias de resposta às lesões no DNA. Os transdutores também devem estar envolvidos na agregação dos complexos de reparo nos sítios de dano no DNA (Zhou \& Elledge, 2000; Shiloh, 2003)

Estima-se que cerca de $2 \times 10^{4}$ eventos de dano ocorram em cada célula por dia. Uma parcela significativa das lesões é causada por espécies reativas de oxigênio (reactive oxygen species - ROS) e a sua produção excessiva e/ou o funcionamento deficiente dos sistemas celulares antioxidantes, que neutralizem a ação de ROS, é conhecido como estresse oxidativo.

ROS é constantemente produzida em células vivas (Nelms et al., 1998; Shiloh \& Kastan, 2001), sendo que as principais fontes endógenas derivam de processos metabólicos, tais como metabolismo primariamente oxidativo nas mitocôndrias, além dos processos patológicos, como inflamações. Pelo fato de ser um sub-produto da respiração, ROS constitui a classe mais expressiva de agentes tóxicos endógenos em organismos aeróbicos. No entanto, nem sempre se origina de sub-produtos de metabolismo celular, às vezes, podendo ser gerada por oxidases específicas, em resposta a fatores de crescimento e citocinas, atuando como mensageiros secundários em vias específicas de sinalização (Abraham, 2001). Em geral, as ROS em níveis fisiológicos normais desempenham uma função reguladora nas vias de sinalização e expressão gênica (Durocher \& Jackson, 2001) e, portanto, a sua produção é de vital importância.

A hipótese dos radicais livres/estresse oxidativo no envelhecimento, a qual foi proposta há anos (Olanow, 1992; Sohal, 1993; Reiter et al., 1994), postula que o acúmulo de espécies reativas de oxigênio relacionado ao envelhecimento resulta em dano na maioria dos componentes celulares: núcleo, DNA mitocondrial, membranas e proteínas citoplasmáticas. O desbalanço entre a produção de radicais livres/ROS e os mecanismos compensatórios desse 
estresse, isto é, os sistemas de defesa, podem estar envolvidos na patogênese da maioria das doenças neurodegenerativas, incluindo doença de Alzheimer (DA), como sugerido por alguns autores (Moreira et al., 2006).

Os neurônios parecem ser particularmente vulneráveis ao ataque de radicais livres, pelas seguintes razões: (1) o seu conteúdo de glutationa, um anti-oxidante natural importante, é baixo (Christen, 2000); (2) as suas membranas contêm uma alta proporção de ácidos graxos poliinsaturados (Hazel \& Williams, 1990); e (3) o metabolismo cerebral requer quantidades consideráveis de oxigênio (Smith et al., 1995). O fato de a idade ser um fator de risco crucial em DA, fornece apoio para a hipótese dos radicais livres/estresse oxidativo, pois os efeitos dos ataques pelos radicais livres, particularmente aqueles produzidos por ROS, podem se acumular ao longo dos anos (Benzi et al., 1995). Tais considerações gerais sugerem que os radicais livres estão envolvidos em muitas patologias relacionadas ao envelhecimento, especificamente em DA e outras doenças neurodegenerativas (Christen, 2000).

Em ROS estão englobadas todas as espécies de oxigênio parcialmente reduzidas, denominadas ânion superóxido $\left(\cdot \mathrm{O}_{2}\right)$, peróxido de hidrogênio $\left(\mathrm{H}_{2} \mathrm{O}_{2}\right)$, radical hidroxil $(\cdot \mathrm{OH})$ e NO; a função primária dessa última é agir como mensageiro secundário no processo de sinalização e, além disso, interage $\operatorname{com} \mathrm{O}_{2}$ para gerar o ânion peroxinitrito ( $\mathrm{ONOO}^{-}$), a molécula responsável pela toxicidade de NO, a qual reside na sua capacidade de alterar diretamente os anéis aromáticos de resíduos de aminoácidos e reagir com sulfidrilas, lipídeos, proteínas e DNA. O ânion de peroxinitrito também pode afetar o estado de energia celular, pela inativação de enzimas-chaves mitocondriais, podendo também levar à liberação de cálcio na mitocôndria - essa atividade ubíqua pode gerar efeitos devastadores na fisiologia e viabilidade celular (Barzilai \& Yamamoto, 2004).

Quanto ao potencial mutagênico dos radicais livres, a 8-hidroxidesoxiguanina $(8-\mathrm{OH}$ $d G)$, por exemplo, uma forma oxidada da guanina, é o maior produto oxidativo de dano que pode produzir mutações $A-T$ para $C-C$ ou $C-G$ para $T-A$, porque ela pareia tanto com adenina quanto citosina (Kohen \& Nyska, 2002). Já foi proposto que, diferentemente das lesões nas forquilhas de DNA, as lesões de bases oxidadas, como a 8-OH-dG e 5-hidroxiuracil, são incorporadas pela DNA polimerase na fita recém-sintetizada, o que indica que a 8-OH-dG pode ser pareada com A da fita molde (Mitra et al., 2001).

As bases oxidadas e os sítios AP, bem como quebras de fita simples, induzidas por ROS, com terminações 3'-fosfoglicolato bloqueadas, são reparadas predominantemente pela via de reparo por excisão de bases (base excision repair - BER). Em E. coli, os genes 
específicos mutM, mutY e mutT protegem a fita de DNA da alta mutagenicidade da guanina oxidada. MutM remove a base oxidada das bases pareadas 8-oxoG-C no duplex de DNA. A DNA glicosilase mutY excisa a adenina mal incorporada à 8-oxoG durante a duplicação e a 8oxodGMPase mutT previne a incorporação da 8-oxo-dGMP na fita nascente de DNA. Os homólogos humanos mutM (OGG1), mutY $(M Y H)$ e mutT (MTH) já foram identificados (Charames \& Bapat, 2003).

O primeiro passo de BER geralmente envolve o reconhecimento e excisão da base inapropriada. Tais substratos das bases incluem-se a uracila, 3-metiladenina, 8-OH-dG e as formamidopirimidinas. Para executar essa etapa inicial do BER, os organismos são equipados com enzimas denominadas DNA glicosilases (Stivers \& Jiang, 2003; Huffman et al., 2005). Elas reconhecem especificamente um determinado número de modificações das bases e catalizam a hidrólise do terminal N-glicosílico (Wilson \& Bohr, 2007). O produto resultante é um sítio abásico com uma extremidade fosfodiéster do DNA intacta. Glicosilases monofuncionais, ou seja, proteínas que exibem apenas uma atividade catalítica, normalmente permanecem ligadas ao DNA, talvez para proteger o sítio abásico da clivagem espontânea da fita e/ou servindo como um sinalizador para os eventos de reparo subseqüentes. Algumas glicosilases, como a 8oxoguanina glicosilase (OGG1) e a proteína similar à endonuclease VIII (NEIL1) são, no entanto, bifuncionais. Isto é, essas enzimas não só excisam o substrato da fita, como também incisam a fita do DNA imediatamente na posição 3' do produto do sítio AP, por meio de uma reação de eliminação $\beta$ ou $\beta, \delta$. A quebra de fita simples resultante da fase da reação de eliminação gera uma extremidade que necessita da conversão para um grupo 3'-hidroxil normal antes da polimerização e ligação

Após ambas as remoções do substrato pela DNA glicosilase bifuncional, a proteína predominante responsável pela execução do próximo passo, em células de mamíferos, é a endonuclease apurínica 1, APE1 (Wilson \& Barsky, 2001; Demple \& Sung, 2005). A APE1 detém a habilidade de incisar a extremidade 5' do sítio AP e remover o terminal 3' obstrutivo, particularmente os resíduos de aldeído 3'- $\alpha-\beta$-insaturados.

Uma vez que os terminais do DNA foram processados para conterem um grupo 3'hidroxil e outro 5'-fosfato e, que os nucleotídeos afetados tenham sido substituídos, o espaço faltante deve ser selado. Essa etapa final é cumprida tanto pela proteína XRCC1, quanto pela DNA ligase $3^{\alpha}$ (LIG3 $\alpha$ ), ou ainda pela proteína individual DNA ligase 1 (LIG1) (Tomkinson et al., 2001). 
A via detalhada anteriormente, envolvendo a DNA POL $\beta$, envolve tipicamente a substituição de um único nucleotídeo e, por isso, os pesquisadores referem-se à ela como a via curta de BER (short-patch BER - SP-BER). Todavia, em alguns casos, geralmente quando a extremidade 5' oferece dificuldade de excisão pela POL $\beta$ AP liase, a síntese da fita removida é necessária e portanto, a incorporação de múltiplos nucleotídeos ocorre (normalmente entre 2 e 7 nucleotídeos). Essa via foi denominada de via longa de BER (long-patch BER - LP-BER) e freqüentemente envolve as polimerases dependentes do antígeno nuclear celular de proliferação (PCNA), isto é, POLE ou POLס (em cooperação com RCF e FEN1) (Figura 1).

Assim como a via anterior, a LP-BER também foi reconstituída com sucesso in vitro usando-se um número restrito de proteínas (Klungland \& Lindahl, 1997; Matsumoto et al., 1999), as que acreditam ser as principais participantes. Enquanto o papel biológico da LP-BER não é totalmente compreendido, existem possíveis conexões emergentes com doenças em humanos e envelhecimento.

Enquanto deficiências em outras vias de reparo, como por excisão de nucleotídeos (nucleotide excision repair - NER) e por erro de pareamento (Mismatch Repair - MMR), estão relacionadas ao câncer e outras doenças, ainda não foram caracterizadas doenças relacionadas à deficiência de BER. Entretanto, estudos recentes demonstraram que a atividade reduzida de OGG1 é o fator de maior risco na formação esporádica de câncer pulmonar em fumantes, associando à deficiência de BER ao desenvolvimento do câncer (Paz-Elizur et al., 2003). Muitas proteínas de NER, em especial XPG (uma endonuclease essencial) também estão envolvidas no reparo da Timina glicol (Tg) in vivo (um outro tipo de base oxidada bem caracterizado), mesmo tendo a sua atividade nuclease dispensável. Isso implica na idéia de que o reparo acoplado à transcrição (transcription-coupled repair - TCR) de bases oxidadas não funciona via NER, sendo BER a via mais provável.

A via de BER é o mecanismo principal para a remoção de lesões endógenas do DNA e que causa distorções pequenas nas hélices. Além disso, BER é necessário para o reparo de tipos similares de danos de base causados por agentes ambientais, tais como alquilações de nitrosaminas e dano de base por radiações ionizantes (Slupphaug et al., 2003). A via BER é iniciada por perda não-enzimática de base, ou por uma DNA glicosilase. Cada DNA glicosilase é específica para um número limitado de bases danificadas (Lindahl \& Wood, 1999; Krokan et al., 2000). As DNA glicosilases podem ser monofuncionais, removendo apenas a base, deixando um sítio abásico intacto (sítios AP), por exemplo, a uracil-DNA glicosilase e alquipurina-DNA glicosilase, ou ainda bifuncionais, pois além de remover a base, ainda tem 
uma atividade de liase, clivando o DNA 3'-OH do sítio abásico, como mencionado anteriormemte. Pelo menos 12 DNA glicosilases humanas diferentes já foram identificadas, dentre elas a OGG1.

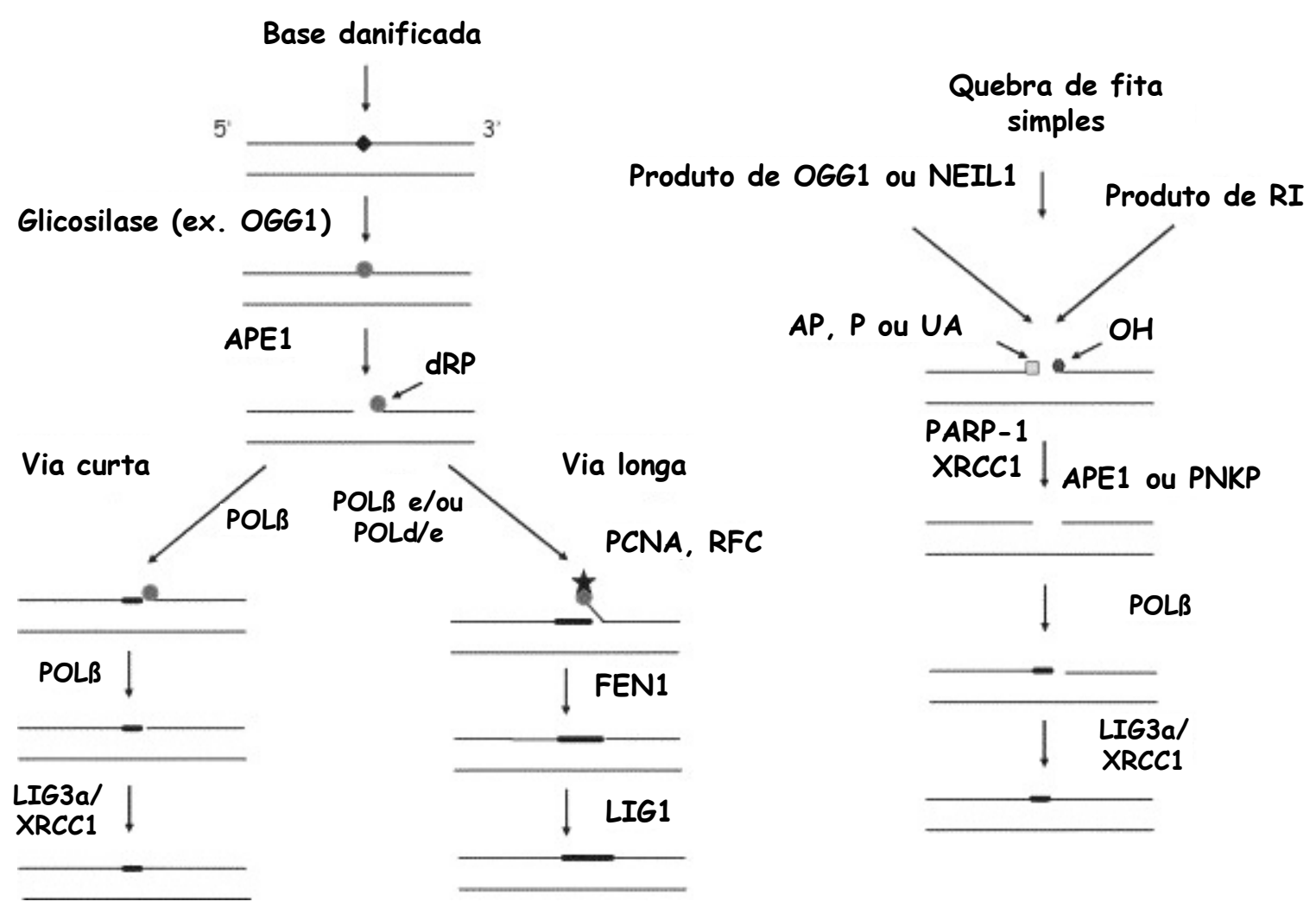

Figura 1: Sub-vias de BER. As vias curta e longa estão apresentadas na parte esquerda da figura; a via de reparo da quebra de fita simples está a direita, onde a lesão inicial pode ser tanto um produto de glicosilase ou ação direta de uma agente (ex: radiações ionizantes). O losango representa o dano ou mau pareamento (ex: uracila); círculo cinza = sítio AP ou o grupo dRP após a incisão de APE1; estrela = resíduo abásico gerado pela atividade $A P$ liase da $P O L \beta$; linha escura = DNA recém sintetizado.

Pela natureza de ambas as vias de BER, a escolha da via é determinada, em parte, pela natureza da DNA glicosilase e do sítio AP resultante, dependendo também da fase do ciclo celular e localização sub-nuclear do processo (Otterlei et al., 1999).

Os radicais superóxido são eliminados pela superóxido desmutase (Superoxide Dismutase - SOD), de onde dois radicais superóxidos e dois prótons geram menos peróxido de hidrogênio e oxigênios reativos. O peróxido de hidrogênio é, por sua vez, convertido à água e 
oxigênio pela catalase. As atividades da SOD estão presentes tanto no núcleo, quanto nas mitocôndrias e mesmo extracelularmente.

Nas células em divisão, as respostas relacionadas aos checkpoints G1-S, S e G2-M permitem às células danificadas um tempo para efetuar o reparo, particularmente no DNA, ou entrar em apoptose, ou num estado permanente de G0 (lliakis et al., 2003). Os peróxidos parecem iniciar bloqueios nos checkpoints em muitos tipos celulares: $\mathrm{H}_{2} \mathrm{O}_{2}$ e hidroperóxido de tert-butil induziram uma resposta em G1 que poderia ser atenuada pela aplicação de antioxidantes; concentrações sub-letais de peróxido de hidrogênio em células de fungos induziram a fosforilação dependente de Mec-1 em Rad53 e um atraso no ciclo celular dependente de Rad53, especificamente durante a fase S. A ausência de fosforilação de Rad53 após tratamento com $\mathrm{H}_{2} \mathrm{O}_{2}$ durante as fases $\mathrm{G} 1$ e $\mathrm{G} 2$ é resultante do reparo silencioso de danos oxidativos pela via BER, produzidos nesses estágios. Apenas a ruptura da via BER e o acúmulo e/ou tratamento de intermediários do DNA por vias alternativas de reparo revelam a existência de lesões primárias no DNA, induzidas em todas as fases do ciclo celular pelo peróxido de hidrogênio (Leroy et al., 2001).

\section{Doença de Alzheimer}

A demência senil denominada Alzheimer é uma doença neurodegenerativa crônica que exerce um considerável impacto na saúde pública, visto que a sua incidência continua a crescer com o aumento da longevidade da população (Sramek \& Cutler, 1999). A doença de Alzheimer (DA) acomete atualmente cerca de 25 milhões de pessoas no mundo, em número absoluto, e a sua prevalência dobra a cada cinco anos a partir dos 65 anos (Jorm et al., 1987); assim, tem-se uma prevalência de 0,7\% no grupo de 60-64 anos, enquanto que no grupo de 90-95 anos essa freqüência aumenta para 38,6\%.

A DA não é a mesma daquela descrita na literatura há mais de dez anos, ou seja, uma patologia causada por "fenômenos misteriosos". Pesquisas no campo da genética e biologia molecular trouxeram muita informação sobre essa doença neurodegenerativa bastante comum. Com o advento de novas formas de abordagem, a identificação de fatores de risco, além de fatores protetores relacionados à DA, tornou-se de fundamental importância. Diversos deles têm sido consistentemente associados ao risco maior da doença, sendo eles: idade, história familiar de demência (van Duijn et al., 1991), fatores genéticos (Saunders et al., 1993; Christen, 2000), trauma craniano (Guo et al., 2000) e doença vascular cerebral prévia (Snowdon et al., 1997). 
Alguns genes envolvidos na patogênese de DA já foram identificados; alguns deles estão presentes nas formas precoces do mal (early-onset) (entre 10 a 15\% dos casos de Alzheimer), antes dos 65 anos de idade, sob a forma de uma doença autossômica dominante familial, e têm um efeito causal direto: o gene da proteína precursora de amilóide (amyloid precursor protein - APP) localizado no cromossomo 21 e os genes da presenilina 1 (PS1) e 2 (PS2), localizados nos cromossomos 14 e 1, respectivamente. Atualmente, mais de 50 mutações sem sentido diferentes, no gene PS1, já foram descritas em cerca de 100 famílias (Campion et al., 1999). Mutações em APP são menos freqüentes nesses casos familiais, sendo que apenas 7 diferentes mutações sem sentido foram descritas, localizadas nos éxons 16 e 17 de APP, em 23 famílias com DA ou fenótipos relacionados (Campion et al., 1999). Mutações no gene PS2 também já foram encontradas, embora estas sejam muito raras (Lendon et al., 1997).

Para as formas tardias da doença (late-onset) - as mais comuns de DA que ocorrem depois dos 65 anos de idade - as quais apresentam padrões muito complexos de herança, o gene da apolipoproteína $\mathrm{E}(A P O E)$, no cromossomo 19, é o único consistentemente associado à doença. Um polimorfismo comum nesse gene $(\varepsilon 4)$ confere um risco acentuado de DA aos indivíduos portadores (Blacker et al., 2003). O gene da macroglobulina a2, localizado no cromossomo 12 e outros genes ainda não identificados, também podem determinar a susceptibilidade nessas formas tardias e esporádicas.

Histologicamente, em DA, o citoesqueleto neurológico se contorce em estruturas denominadas emaranhados neurofibrilares (ENF). Fora da célula, os peptídeos amilóide $\beta$ (A $\beta$ ) se agregam em oligômeros, os quais se acumulam e formam depósitos denominados de placas amilóides. Esses depósitos de $A \beta$ podem ocorrer em qualquer órgão e, normalmente, são grandes e amorfos; já os depósitos de amilóide cerebrais tomam formas delimitadas de placas (Nicoll et al., 1996; Kim et al., 2002; Li et al., 2004).

Parece existir uma cascata de eventos que levam ao processo de amiloidogênese e, mais especificamente, à formação e deposição de um peptídeo grande de amilóide $\beta$ (de 42 ou 43 aminoácidos). $A$ maioria da $A \beta$ é composta por um peptídeo designado $A \beta 40, A \beta_{40}, A \beta_{1-40}$ ou, em alguns casos, $A \beta_{x-40}$. Peptídeos com vários terminais amino, todos contendo terminações carboxil idênticas, formam a proporção maior (mais de 95\%) da $A \beta$ produzida pelas células (Naslund et al., 1994). Uma fração menor (menos de 5\%) das $A \beta$ produzidas terminam no resíduo 42 (Naslund et al., 1994). Essa $A \beta$, denominada $A \beta_{1-42}, A \beta 42, A \beta_{42}$ ou $A \beta_{x-}$ 42, é muito mais agregável que a $A \beta 40$, havendo evidências de que essa forma de peptídeo 
inicie a formação dos oligômeros, fribrilas e placas (Younkin, 1995).

Em vários casos em que mutações já foram identificadas nos genes APP, PS1 e PS2, em todas houve uma produção acentuada de tal peptídeo (Wyss-Coray et al., 1997). Muitos fatores complementares, incluindo citocinas, fator de crescimento transformador $\beta 1$ e interleucina 1, parecem estar envolvidos no início do processo de amiloidogênese (Wyss-Coray et al., 1997).

Muitos estudos demonstraram um efeito tóxico direto da amilóide $\beta$ em culturas de neurônios ou linhagens celulares. Se isso reflete ou não a situação in vivo não é conhecido, mas o fenômeno pode fornecer informações importantes para explicar o papel do processo amiloidogênico na patogênese de DA. Behl e colaboradores mostraram que essa toxicidade da amilóide $\beta$ em células PC12 é suprimida pela vitamina E e por anti-oxidantes em geral (Behl \& Sagara, 1997). Em um outro estudo, o autor demonstrou que o peróxido de hidrogênio medeia a toxicidade de amilóide $\beta$, sendo que a catalase, que degrada o peróxido de hidrogênio, protege as células da toxicidade da amilóide $\beta$ (Behl et al., 1994). Esse mesmo grupo selecionou clones de células PC12 resistentes à toxicidade de amilóide $\beta$ e mostrou que elas continham altas concentrações das enzimas anti-oxidantes catalase e glutationa peroxidase (Sagara et al., 1996).

Assim como os processos oxidativos podem transformar, in vitro, as $\beta$-amilóides nãoagregadas em agregadas (Dyrks et al., 1992), a própria $\beta$-amilóide constitui uma fonte de radicais livres. Esta interage com células vasculares endoteliais, produzindo um excesso de radicais superóxido livres, que podem captar o fator relaxante derivado do endotélio e produzir agentes oxidantes, causando a peroxidação de lipídeos. Segundo os autores, até mesmo esse foco no endotélio vascular, e não nos neurônios, pode apoiar a hipótese de que a $\beta$-amilóide atua na produção de radicais livres, exercendo uma função importante nos processos neurodegenerativos (Thomas et al., 1996).

O aumento na atividade de NF-KB protege os neurônios contra a toxicidade da $\beta$ amilóide (Barger et al., 1995). Dados novos sugerem que o NF-kB desempenha um papel essencial em doenças neurodegenerativas. Goodman e Mattson (1996) mostraram que a ativação de NF-KB pode constituir uma via de sinalização citoprotetora que induz a expressão de produtos gênicos protetores, como a calbindina e enzimas anti-oxidantes (Goodman \& Mattson, 1996). De fato, a exposição de células ao estresse oxidativo, resulta na ativação de NF-KB (Behl \& Sagara, 1997) e uma atividade altamente constitutiva desse fator medeia a resistência ao estresse oxidativo em células neuronais (Lezoualc'h et al., 1998). Entretanto, 
esses resultados contradizem os apresentados por outros autores (Grilli et al., 1996), os quais discutem a função neuroprotetora da aspirina, a qual é mediada através da inibição de NF-KB. Um outro estudo fornece uma explicação para esses dados contraditórios: a ativação de NFKB de células gliais é provavelmente neurotóxica, mas o seu envolvimento em neurônios é provavelmente neuroprotetor (Barger et al., 1995).

Como mencionado anteriormente, embora a forma tardia de DA seja caracterizada como uma herança bastante complexa, ao menos um importante fator de risco genético é conhecido em aproximadamente $25 \%$ da população com DA e esse é o genótipo APOE $\varepsilon 4$ (Mayeux et al., 1993; Helbecque \& Amouyel, 2000). A apoE (codificada pelo gene APOE) é uma proteína transportadora de colesterol que atua tanto no sistema vascular, quanto através dos neurônios e se liga, primeiramente, ao receptor do colesterol de baixo peso molecular (Low Density Lipoprotein receptor - LDLR) e à proteína relacionada à LDLR (LDLP-related - LRP). No cérebro, a apoE é o principal carreador de colesterol, desempenhando fenômenos relacionados à neuroplasticidade, pois eles requerem alterações nos lipídeos da membrana e, portanto, uma função dependente de colesterol.

A forma mais comum de $A P O E$ é o tipo $\varepsilon 3$, contendo uma cisteína no resíduo 112 e uma arginina no resíduo 158. No entanto, cerca de $15 \%$ dos alelos de $A P O E$ na população geral são do tipo $\varepsilon 4$, no qual a císteina no resíduo 112 é substituída por arginina. Na população dos pacientes com DA a freqüência desse alelo é triplicada, cerca de 45\% (Mayeux et al., 1993). Em contrapartida, o alelo APOE $\varepsilon 2$ parece proteger contra o desenvolvimento de DA (St George-Hyslop et al., 1994). Esforços para tentar relacionar o APOE $\varepsilon 4$ com o acúmulo de $A \beta$ têm trazido resultados conflitantes: a $a p o E \varepsilon 3$, e não a $a p o E \varepsilon 4$, forma complexos com $A \beta$ que são resistentes à denaturação, segundo LaDu e colaboradores (LaDu et al., 1994).

Um outro modelo que poderia explicar, parcialmente, os efeitos de $\varepsilon 4$ envolve uma deficiência relativa dessa isoforma como um anti-oxidante, uma vez que esta não tem resíduos de cisteína, presentes em $\varepsilon 2$ e $\varepsilon 3$, os quais ajudam a tamponar os efeitos do estresse oxidativo (Miyata \& Smith, 1996). Segundo Poirier, a apoE tem um efeito benéfico para a proteção neuronal, mas a isoforma $\varepsilon 4$ é menos efetiva do que as isoformas $\varepsilon 2$ e $\varepsilon 3$, ou seja, apo $\varepsilon 4$ pode não ser tóxica, mas simplesmente é incapaz de produzir um efeito favorável (Poirier, 1999).

Os processos que clivam a APP também podem trazer fortes indícios sobre o desenvolvimento de DA. A via da a-secretase é sensível à PKC (Caporaso et al., 1992), MAPK/ERK (Mills et al., 1997), proteína quinase associada a RHO (ROCK) (Pedrini et al., 2005) e proteínas fosfatases 1 e 2A (PP1, PP2A) (Caporaso et al., 1992). Como resultado, 
quando ocorre a transdução de sinais que envolvem a ativação de PKC ou MAPK/ERK, ou ainda, a inativação de PP1, PP2A ou ROCK, o metabolismo de APP é drasticamente levado à via mediada por $\alpha$-secretase, ao invés da via mediada por $\beta$-secretase e formação de $A \beta$ (Buxbaum et al., 1998). Esses resultados evidenciam a competição entre as duas vias e exclusividade mútua. Esse fenômeno, conhecido como clivagem regulada ou segregação regulada de ectodomínio, parece acontecer graças, ao menos em parte, à redistribuição de APP fora dos compartimentos intracelulares e para fora na membrana plasmática, onde o APP pode encontrar a $\alpha$-secretase. A a-secretase, por si mesma, também pode ser redistribuída na membrana plasmática. As estatinas provavelmente diminuem a concentração de $A \beta$, estimulando a $\alpha$-secretase a produzir um padrão de processamento que é indistinguível da clivagem regulada, modulada por PKC e MAPK/ERK (Kojro et al., 2001).

A A $\beta$ é clivada a partir da APP seqüencialmente pela $\beta$ - e então pela $\gamma$-secretase. Entretanto, a formação de $A \beta$ é de ocorrência relativamente rara em cérebro de indivíduos normais; normalmente a APP é clivada primeiro pela $\alpha$-secretase, ao invés da $\beta$-secretase, inibindo a produção de $A \beta$. A enzima responsável pela maior parte da clivagem de $\beta$-secretase é uma proteinase integral de membrana aspartil, conhecida como enzima de clivagem $\beta$ secretase (BACE). A identidade das $\alpha$-secretases também são conhecidas - ADAM10 (uma desintegrina e metaloproteinase) (Lammich et al., 1999) e ADAM17, também conhecida como enzima conversora de fator de tumor de necrose (TACE) (Buxbaum et al., 1998), ambas capazes de clivar APP no sítio de clivagem da a-secretase, sendo que a ADAM9 (Hotoda et al., 2002) também parece participar.

Com o advento de novas formas de abordagem, a identificação de fatores de risco, além de fatores protetores relacionados à DA, tornou-se de fundamental importância. Diversos deles têm sido consistentemente associados ao risco aumentado da doença, tais como a idade, história familiar de demência, fatores genéticos, trauma craniano e doença vascular cerebral prévia.

A inativação de um transdutor que medeia a resposta ao dano no DNA pode levar ao acúmulo de danos, perda da homeostase e alterações no estado redox celular, sendo que perturbações no balanço de espécies reativas de oxigênio (ROS), resultando em estresse oxidativo, constituem um denominador comum das síndromes de instabilidade genômica, que refletem um defeito nas respostas aos danos no DNA (Moreira et al., 2006). Assim, um estudo enfocando os níveis de expressão gênica diferencial para uma série de genes-alvo mostra-se relevante para melhor caracterizar a DA. Para a doença de Alzheimer, dados na literatura 
apontam para alguns genes-alvo que possam estar relacionados à patologia: o $A P P, P S 1 \mathrm{e}$ PS2 são genes cujos produtos participam diretamente na produção e deposição de amilóides $\beta$ (placas amilóides), peptídeo comprovadamente tóxico às células humanas. Parece existir uma cascata de eventos que levam ao processo de amiloidogênese. Ainda, em trabalhos em que foram encontradas mutações nos genes APP, PS1 e PS2, verificou-se uma produção acentuada de tal peptídeo (Wyss-Coray et al., 1997).

Entretanto, somente um fator de risco genético é conhecido nesses casos, relacionado ao genótipo $A P O E \& 4$ (sendo a apoE codificada pelo gene $A P O E$ ). Esse isótipo confere um risco acentuado de Alzheimer aos indivíduos portadores (Blacker et al., 2003). 


\section{OBJETIVOS}

\section{Objetivos gerais}

O objetivo do presente trabalho foi o de analisar a expressão diferencial de genes envolvidos na resposta ao dano oxidativo no DNA, bem como avaliar o efeito do estresse oxidativo na produção de quebras na fita de DNA, causadas por bases oxidadas, em linfócitos de pacientes de Alzheimer, grau moderado, comparados a um grupo controle de indivíduos sadios.

\section{Objetivos específicos}

- Avaliar o efeito do estresse oxidativo na produção de quebras na fita de DNA, causadas por bases oxidadas, em linfócitos de pacientes DA e controles.

- Comparar os níveis de expressão (pelo método de qPCR) de uma série de 20 genes de reparo e percepção de dano oxidativo em linfócitos de pacientes DA e controles;

- Avaliar os perfis de expressão gênica em linfócitos de pacientes com Alzheimer e contextualizá-los num espectro mais amplo, por meio da análise por microarranjos de cDNA, a fim de verificar a existência de uma possível associação destes aos processos celulares verificados em DA, comparados aos indivíduos sadios;

- Detectar, por meio de estudos de perfis de expressão e análise de agrupamento gênico (dados obtidos por microarranjos), genes ou classes de genes com expressão significativamente alterada, relativamente aos controles, que possam discriminar o grupo de pacientes DA com o grupo controle. 


\section{MATERIAL E MÉTODOS}

\section{Seleção de pacientes com a doença de Alzheimer}

Os pacientes escolhidos para o presente estudo já sofreram uma triagem e selecão (para um estudo anterior, tese de doutorado do Dr Charlys B. Nogueira) nos ambulatórios de geriatria (AGER), ambulatório de geriatria de pacientes de alta dependência (GEAD) e ambulatório de triagem em geriatria (GERI) do Hospital das Clínicas da Faculdade de Medicina de Ribeirão Preto/Universidade de São Paulo, com consentimento prévio da comissão de ética em pesquisa competente.

O trabalho foi submetido à avaliação pelo comitê de ética local, do HC-FMRP e aprovado (Anexo). As amostras de sangue (dos pacientes e controles) foram coletadas com o consentimento dos doadores e, preservando a liberdade dos mesmos em retirar o seu consentimento a qualquer momento, sem que isso trouxesse qualquer prejuízo a eles, sendo mantida, também, a privacidade dos mesmos. O grupo de pacientes DA envolveu 12 mulheres de sexo feminino, com idade média de $78 \pm 6,36$ anos e escolaridade entre um e oito anos. Todas as participantes foram submetidas, no estudo anterior, à entrevista estruturada ENEDAM (Entrevista Estruturada para o Diagnóstico de Demência do tipo Alzheimer, Demência por Múltiplos Infartos e Demência de Outras Etiologias) (Zaudig et al., 1991; Zaudig, 1992), para auxílio no diagnóstico de DA. Para excluir outras causas de demência, também foram realizados o Mini Exame do Estado Mental (MEEM) (Folstein et al., 1975), o teste do relógio, o teste de fluência verbal e a Escala Clínica de Demência (Clinical Dementia Rating - CDR) (Hughes et al., 1982).

As voluntárias apresentaram diagnóstico de DA provável, com base nos critérios propostos pelo DSM-IV (Manual de Diagnóstico e Estatística de Transtornos Mentais), DSM-III$\mathrm{R}$ (Idem - 3a Ed revisada) (Association, 1987), NINCS-ADRDA (National Institute of Neurological and Communicative Disoreders and Stroke and the Alzheimer's disease Related Disorders Association) (McKhann et al., 1984) e CID-10 (Código Internacional das Doenças) (World Health Association, 1992). Além disso, foram selecionadas apenas as voluntárias com escore isquêmico de Hachinski (Hachinski et al., 1975) abaixo de quatro (valores acima desse limiar referem-se à demência por múltiplos infartos). Todas as pacientes também passaram por uma série de exames de rotina (para avaliação de síndromes demenciais, visando excluir outras causas de demência que não a DA: tomografia computadorizada de crânio sem contraste, hemograma completo, dosagem de sódio, potássio, cálcio total e ionizado, provas de 
função renal e hepática, enzimas hepáticas, hormônios tireoidianos e sorologia para sífilis e HIV. Todas as avaliações foram feitas por um médico especialista responsável da própria instituição (HC-FMRP). Vale ressaltar ainda que, por se tratar de um grupo de DA moderado provável, todas as pacientes estavam sob medicação de inibidores de acetil-colinesterase $A$ (Donepezil ou Rivastigmina), conduta comum nos ambulatórios de geriatria e demência.

Para a integração do grupo controles, 12 indivíduos sadios, também do sexo feminino, foram selecionados, com idade média de $76 \pm$ 4,31 anos, os quais não apresentavam queixas de memória no momento da avaliação e foram diagnosticados normais do ponto de vista cognitivo, por avaliação clínica com anamnese detalhada. Todos os indivíduos controles também foram submetidos ao Mini Exame do Estado Mental (MEEM) (Folstein et al., 1975), o teste do relógio e o teste de fluência verbal (Hughes et al., 1982).

\section{Coleta das amostras de sangue e cultura de linfócitos}

Por ocasião do retorno das pacientes ao ambulatório e após a consulta especializada, juntamente com as entrevistas já descritas, as amostras de sangue de ambos os grupos foram coletadas. Para todos os testes, foram colhidos $20 \mathrm{~mL}$ de sangue/indivíduo, por punção venosa, usando tubos Vacutainer (Beckton \& Dickinson, EUA) contendo EDTA e os linfócitos foram imediatamente separados, utilizando-se Histopaque 1077, segundo orientações do fabricante (Sigma Chemical Co, USA). Uma pequena alíquota de sangue total (cerca de 500 $\mu \mathrm{L})$ foi reservada durante a separação dos linfócitos, para a execução dos testes do Cometa.

\section{Ensaio do Cometa e tratamento com enzima para a detecção de dano oxidativo no DNA}

Logo após a retirada do sangue, $20 \mu \mathrm{L}$ foram acrescidos a $240 \mu \mathrm{L}$ de agarose de baixo ponto de fusão $\left(37^{\circ} \mathrm{C}\right) \quad 0,5 \%$, misturando-se levemente. O material foi então, transferido para duas lâminas recém-preparadas com a primeira camada de agarose de ponto de fusão normal $1,5 \%$. As lamínulas foram colocadas sobre o material e em seguida, as lâminas foram levadas à geladeira por 5 minutos, quando as lamínulas foram retiradas. Em seguida, as lâminas serão mergulhadas em solução de lise - contendo $\mathrm{NaCl}$ 2,5M; EDTA 100mM; Tris 10 mM; DMSO $10 \%$; Triton X-100 1\%, pH 10 - recém preparada, por 2 horas, permanecendo a $4^{\circ} \mathrm{C}$ durante todo o tempo em solução de lise (por até 5 dias).

Depois da lise, as lâminas foram imersas, 2 vezes, em tampão F [(HEPES 40 mM; KCl 0,1 M; EDTA 0,5 mM e 0,2 mg/mL ( $\mathrm{pH}=8.0$ )] por 5 minutos cada, e a $4^{\circ} \mathrm{C}$. A enzima hOGG1 foi diluída em $50 \mathrm{~mL}$ de tampão $\mathrm{F}$, em diluições previamente estabelecidas para a aquisição da 
maior percentagem de quebras possíveis - o equivalente à cerca de 0,08 U por gel. Em seguida, as lâminas foram cobertas por lamínulas e incubadas em uma câmara úmida por 10 minutos, a $37^{\circ} \mathrm{C}$.

Ao final desse tempo, as lamínulas foram removidas e as lâminas mergulhadas em solução tampão de eletroforese ( $\mathrm{NaOH} 300$ mM; EDTA $1 \mathrm{mM}, \mathrm{pH}=13)$ por 20 minutos, a $4^{\circ} \mathrm{C}$. Transcorrido esse tempo, as lâminas foram levadas para a cuba de eletroforese, preenchendoa com solução tampão até cobrir as lâminas e, enfim submetidas à uma eletroforese a 25V/300mA por mais 20 minutos. Depois disso, as lâminas foram imediatamente imersas em solução de neutralização (Tris $0,4 \mathrm{M}$; $\mathrm{Ph} 7,5$ ) por 15 minutos, à temperatura ambiente e então, coradas com $50 \mathrm{~mL}$ de iodeto de propídio $(10 \mathrm{mg} / \mathrm{mL})$ e contadas.

A quantificação das células foi feita através do software CometScore ver.1.5 (TriTrek Corp./USA) e os dados submetidos à análise estatística. Foram contadas um total de 75 células/indivíduo.

\section{RT-PCR e PCR em tempo real}

Para os experimentos de RT-PCR e PCR em tempo real, foram utilizadas as amostras de 5 indivíduos de cada grupo. A qualidade e integridade do RNA foram verificadas anteriormente, bem como a reação de RT-PCR, através da eletroforese de gel de agarose denaturante (SIGMA, EUA).

As extrações de RNA total de todas as amostras foram feitas com o reagente Trizol (Gibco BRL) conforme as instruções do fabricante e a quantificação do RNA extraído também foi feita, por um espectrofotômetro GeneQuant (Amersham, EUA). Para remover quaisquer resquícios de DNA da amostra de RNA, foi usado o kit Deoxyribonuclease I, Amplification Grade (Invitrogen).

Para a RT-PCR, foi utilizado o kit Superscript III Reverse Transcriptase (Invitrogen); adicionando $1 \mu \mathrm{L}$ de oligo DT primer (250ng/ $\mu \mathrm{L})$ aos RNAs provenientes das amostras da reação com a DNase e incubados a $70^{\circ} \mathrm{C}$, por 10 minutos e, ao final, colocados no gelo. Adicionou-se aos tubos um mix contendo $4 \mu \mathrm{L}$ de First-strand buffer $5 \mathrm{X}, 2 \mu \mathrm{L}$ de DTT $0,1 \mathrm{M}, 1 \mu \mathrm{L}$ de dNTP $10 \mathrm{mM}$ e $1 \mu \mathrm{L}$ de Superscript III RT 200U/ $\mu \mathrm{L}$ (Invitrogen), incubando-se por 50 minutos, a $50^{\circ} \mathrm{C}$ e, no final, à uma temperatura de $70^{\circ} \mathrm{C}$ por 15 minutos. Ao final da reação foi realizada uma reação de PCR convencional para um gene constitutivo, a ACT $\beta$, a fim de testar a integridade das amostras de cDNA. 
As reações de PCR em tempo real foram preparadas a partir de um mix contendo $9 \mu \mathrm{L}$

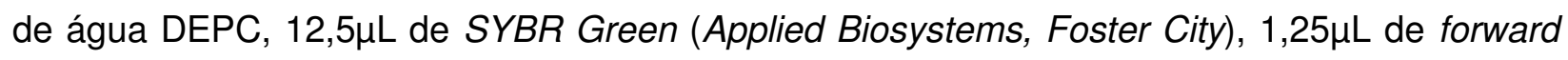
primer e $1,25 \mu \mathrm{L}$ de reverse primer para cada gene a ser testado e $1 \mu \mathrm{L}$ do produto de PCR das amostras de cDNA e, todas elas foram preparadas em placas de polipropileno para 96 reações (Applied Biosystems, Foster City), cobertas com adesivos para microplacas resistentes a altas temperaturas (Apllied Biosystems, Foster City). Na tabela 1 consta a relação dos pares de primers utilizados nessa metodologia.

\section{Microarranjos de cDNA}

As análises dos perfis de expressão gênica apresentadas pelos linfócitos coletados foram feitas utilizando lâminas de vidro para microarranjos contendo 4.300 seqüências (em duplicatas) adquiridas a partir de uma biblioteca humana com cerca de 9.000 clones proveniente do consórcio IMAGE (http://image.IInl.gov), gentilmente disponibilizada pelo Prof. Dr. Geraldo A. S. Passos e pela Dra. Catherine Nguyen do Centre d'Immunologie MarseileLuminy, Marseille, França e preparada de acordo com o protocolo descrito por Hegde e colaboradores (Hegde et al, 2000).

Os microarranjos em lâmina de vidro foram preparados por um robô array spotter e as imagens adquiridas por um array scanner, ambos da linha Generation III Microarray System (Amersham Pharmacia Biotech - MD), seguindo as recomendações do fabricante.

As sondas complexas de cDNA foram preparadas a partir de amostras de RNA extraídas de linfócitos de pacientes com Alzheimer e seus respectivos controles e, em seguida, foi realizada transcrição reversa com $10 \mu \mathrm{g}$ de RNA total de cada amostra, na presença de fluorocromos Сy3 e Cy5 (CyScribe Post Labelling Kit, Amersham Biosciences, England) e oligo dT12-18 como primer.

O RNA de referência foi composto por RNA extraído de três diferentes linhagens celulares: U343 MG-a (linhagem humana de glioma), HeLa (células de carcinoma cervical) e Jurkat (células T-leucêmicas). O RNA dessas células foi extraído e misturado em iguais proporções, sendo estocado a $-80^{\circ} \mathrm{C}$. Esse pool de referência garante que cada hibridação no microarranjo seja realizada com uma amostra de referência idêntica, marcada com Cy3. Esta é hibridada com amostras provenientes dos controles ou paciente, marcadas com Cy5.

As sondas complexas foram purificadas com colunas GFX TM (Amersham Pharmacia Biotech), para remoção dos nucleotídeos e dos fluorocromos não incorporados. As lâminas de 
Tabela 1: Lista de primers utilizados nas reações de RT-PCR ( $A C T B$, especificamente) e qPCR em Tempo Real.

\begin{tabular}{|c|c|c|c|}
\hline & Forward Primer & Reverse Primer & Amplicon \\
\hline ACTB & GATGAGATTGGCATGGCTTT & ATTGTGAACTTTGGGGGATG & 14141 \\
\hline ADAM17 & СTTTCTGCGAGAGGGAACAG & CATCGACATAGGGCACACAG & 111 \\
\hline APEX1 & ATATTGCTTCGGTGGGTGAC & GCTCTGTCCTGAGCTCATCC & 115 \\
\hline APOE & CACTGTCTGAGCAGGTGCAG & TCCAGTTCCGATTTGTAGGC & 112 \\
\hline APP & GCAGAACGGCTACGAAAATC & ACACCGATGGGTAGTGAAGC & 118 \\
\hline ATM & TGACTTTTCAGGGGATTTGG & TAGGAATCAGGGCTTTTGGA & 147 \\
\hline ATR & GACTCAATGGTATCTACTGTGG & GATTCAAAGTGCATTACAGCTC & 136 \\
\hline BACE1 & |TAACCCCCTAAGCTCCAGGT & GAGGAAGATTTGGGGGAAAG & 105 \\
\hline DUSP1 & GAAGGACATTTGGGCTGTGT & CGCTTTTGGACTGAGAGAGG & 113 \\
\hline ERCC1 & CCTATGAGCAGAAACCAGC & TGTTCCAGAGATCCAAATGTG & 144 \\
\hline ERCC3 & GCAAATCTGCCATTTCTAAGAC & CATAGAAGTCAAACAGGTCCA & 110 \\
\hline ERCC6 & GGGCAAGACCATCCAGATAA & АТTССТTСАСССАСТGАTGC & 146 \\
\hline FANCG & CTGTTCTTCCCTTGGAGCTG & TCTCTAGGCTCCGCTGGATA & 107 \\
\hline FEN1 & |CCAGCTCTTCTTGGAACCTG & CGCTCCTCAGAGAACTGCTT & 120 \\
\hline HUS1 & AGCTGCAGCATTTGGAGTCT & CAGAAGGAGCTCCCAGCTAA & 119 \\
\hline OGG1 & AGAAATTCCCCAAGCACCTT & CCTGGCCTTTGAGGTAGTCA & 106 \\
\hline PRKDC & ATAGGTTTCAACATCGGAGAC & GCTCCTCAATGCTCTGTG & 147 \\
\hline RAD1 & ACCCTTTGATGCTGTTCCTG & TGGTGCTGCAGAAATCAAAG & 102 \\
\hline RAD17 & GAAGCTAACAAGAATGGAGGA & GGCTGTTTATTGCACTTCTG & 102 \\
\hline RADg & CCAGCTGGCTGTCACTGTAA & TAGTTCAGGGCCAAGTCTGG & 105 \\
\hline TREX1 & TGACGGACTGTGAAGAGG & GTTGATGTGGTAAGGAAAGGA & 142 \\
\hline
\end{tabular}


microarranjos foram hibridadas com as sonda complexas fluorescentes na presença de Hybe Solution, segundo o protocolo que acompanha os reagentes (Amersham Pharmacia Biotech).

\section{Forma de análise dos dados}

Ensaio do cometa

Foram analisadas 75 células/cultura/indivíduo, sendo observadas as células com contorno circular (núcleos sem danos de DNA) ou em forma de "cometa" (núcleos com danos no DNA), no qual a extensão da cauda reflete a distância de migração da fita de DNA danificada. Para a análise dos danos no DNA, optou-se pela quantidade de DNA na cauda (em \%) e o momento da cauda, ambos os parâmetros oferecido pelo software.

\section{PCR tempo real}

Com a obtenção dos valores de $\mathrm{C}_{\mathrm{T}}$, fornecidos pelo software Gene Amp 7500 Sequence Detection System, determinados individualmente e manualmente para cada gene, os dados foram exportados para uma planilha do Excel (Microsoft Inc.) para análise. O método utilizado para a análise foi feito de acordo com o proposto por Livak \& Schmittgen (Livak \& Schmittgen, 2001).

\section{Microarranjos de cDNA}

Os procediments de filtragem, normalização e análise dos resultados obtidos para os experimentos de microarranjos de cDNA, foram realizados no ambiente estatístico R (Ihaka \& Gentleman, 1996), e no programa MEV.

A quantificação da imagem foi feita pelo software Spot (http://spot.cmis.csiro.au/spot/, CSIRO, Austrália). A filtragem, normalização e análise dos dados foram submetidas ao ambiente estatístico R (Ihaka, 1996), de acordo com as instruções do pacote KHT (http://www.biotech.kth.se/molbio/microarray/7userguide/ usersguide.htm), que implementa bibliotecas de funções para a filtragem, normalização e análise de dados provenientes de experimentos de microarranjos de cDNA.

Os valores de background de cada amostra foram subtraídos e os spots foram avaliados pela sua circularidade e pela média x desvio padrão e, posteriormente, foi realizado o método de normalização Lowess e estabelecimento dos valores $\mathrm{M}$, pelo valor de MAD (Median Absolute Deviation) (Yang \& Speed, 2002). Os dados normalizados foram exportados para o formato MEV e analisados pelo software MEV (http://www.tm4.org/mev.html), sendo a análise estatística processada por ANOVA e SAM (Significance Analysis of Microarrays). 
As informações sobre a localização dos genes e suas funções biológicas foram obtidas a partir de S.O.U.R.C.E. (http://genome-www5.stanford.edu/cgi-bin/source/) e NCBI (http://www.ncbi.nlm.nih.gov/). O método de False Discovery Rate (FDR) foi usado para quantificar o erro das amostras como um todo e, em seguida, aplicado para ajustar os valores $p$ estatísticos para a expressão do erro (Smyth, 2004). Os genes considerados significativamente modulados foram selecionados para FDR $\leq 0,061$.

Adicionalmente, foi também realizada uma análise de agrupamento hierárquico dos dados, usando-se o programa MEV, sendo utilizados os valores normalizados, obtidos de cada duplicata experimental, para aumentar o refinamento do agrupamento gênico. Nessa análise, foram selecionados 187 genes indicados pelo SAM (com FDR $\leq 0,176$ ). 


\section{Resultados}

\section{Análise de danos no DNA pelo ensaio do Cometa}

O ensaio do cometa foi aplicado para avaliar a indução e processamento de danos no DNA em amostras de um total de 24 mulheres não-fumantes, sendo que entre estas, 12 pacientes apresentavam a doença de Alzheimer (grupo DA) - grau moderado, e 12 não apresentavam a doença (grupo controle).

Dentre as diversas variáveis fornecidas pelo software CometScore ${ }^{\mathrm{TM}}$ ver 1.5 (TriTrek Corp./USA), optou-se pela quantidade de DNA na cauda do cometa. Paralelamente, foram realizados testes estatísticos com o momento da cauda (Tail Moment) (dados não apresentados), mas com essa variável não foi possível realizar qualquer análise estatística. De qualquer forma, tanto os valores da quantidade de DNA na cauda, quanto o momento da cauda, obtidos para cada grupo, encontram-se na tabela 2, bem como o gráfico (Figura 2).

Os resultados obtidos demonstraram que em quase todos os grupos (exceção na comparação entre o grupos DA e Co) houve uma diferença significativa entre eles $(p<0,01)$, quando submetidos ao teste de ANOVA, $\alpha=0,05$, seguido pelo método de Student-NewmanKeuls, para a comparação múltipla entre todos os grupos pareados. Anteriormente, em uma análise preliminar, todos os grupos passaram pelo teste de normalidade e de igualdade de variâncias.

Entretanto, nesse teste, os grupos controle (4,18\% de DNA na cauda) versus pacientes Alzheimer (5,59\%) não apresentaram diferenças significativas $(p<0,01)$ entre eles. Entretanto, quando os dados foram submetidos ao teste-t, a análise pareada mostrou diferenças significativas $(p=0,02)$ entre os grupos DA e controle, embora o poder do teste tenha sido menor $(P=0,60)$, comparado ao obtido no teste de ANOVA $(P=1,0)$. Assim, embora os resultados obtidos por ANOVA apresentem um maior nível de confiança, o Teste-t indicou claramente uma tendência dos pacientes Alzheimer a apresentarem um maior nível de danos no DNA.

Após o tratamento com a enzima hOGG1, específica no reparo de alguns danos oxidativos, ambos os grupos demonstraram diferenças significativas $(p<0,01)$ quando submetidos ao teste-t pareado. Para o grupo controle $(4,18 \%)$, a percentagem de DNA na cauda aumentou cerca de 3 vezes (12,99\%), enquanto que para o grupo DA (5,59\%), a diferença foi bem menor (1,3 vezes - 7,25\%). 
Tabela 2: Valores das médias encontradas para as duas variáveis: quantidade de DNA na cauda (\% DNA) e Tail Moment (TM) em cada grupo de indivíduos, controle (Co) e pacientes (DA). $\mathrm{DP}=$ desvio padrão e $\mathrm{EP}=$ erro padrão.

\begin{tabular}{c|c|r|r|r} 
& & Média & DP & EP \\
\hline \hline \multirow{2}{*}{ Co } & \% DNA & 4,18 & 0,94 & 0,30 \\
& TM & 2,71 & 1,88 & 0,59 \\
\hline Co + & \% DNA & 12,99 & 3,96 & 1,25 \\
hOGG1 & TM & 20,93 & 11,57 & 3,66 \\
\hline \multirow{2}{*}{ DA } & $\%$ DNA & 5,59 & 1,44 & 0,46 \\
& TM & 4,44 & 2,32 & 0,74 \\
\hline DA + & $\%$ DNA & 7,26 & 0,96 & 0,30 \\
hOGG1 & TM & 5,96 & 1,88 & 0,59 \\
\hline \multirow{2}{*}{ H2O2 } & $\%$ DNA & 6,39 & 2,25 & 0,71 \\
& TM & 4,29 & 2,29 & 0,73 \\
\hline \hline \multicolumn{4}{|r}{}
\end{tabular}

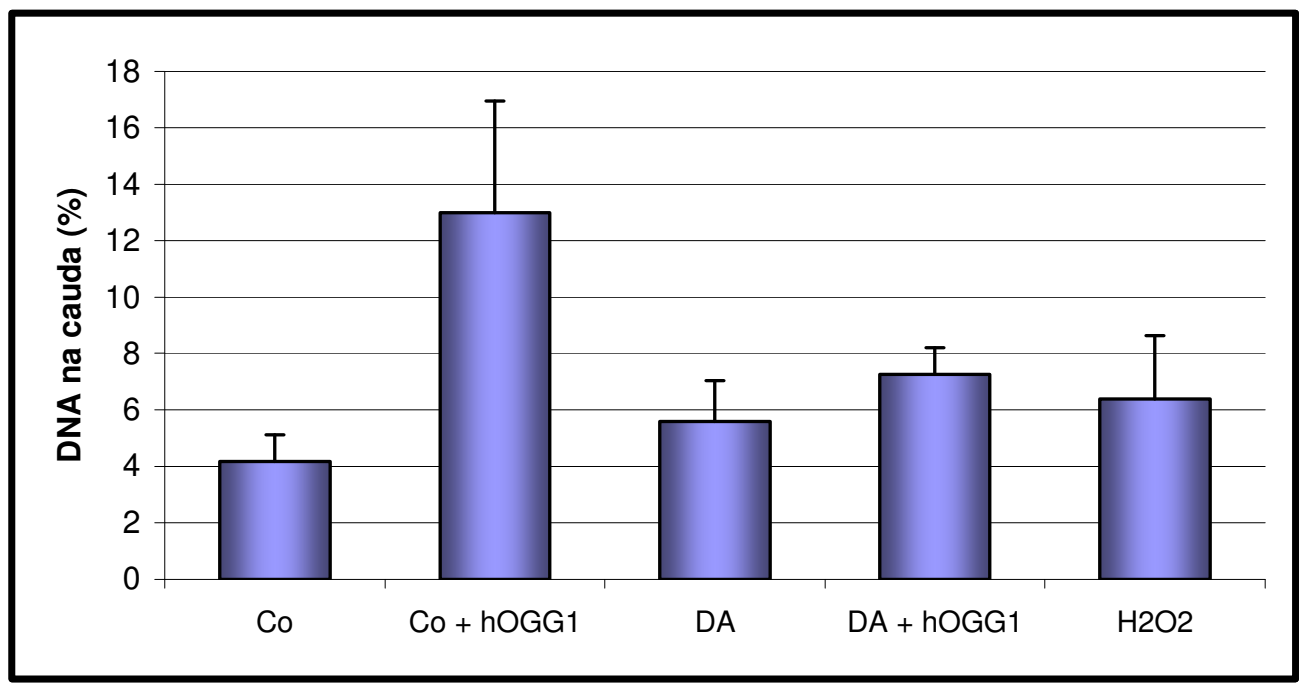

Figura 2: Percentagem de DNA na cauda do cometa, em grupos controle não-tratados com a enzima hOGG1 (Co) e tratados (Co + hOGG1) e pacientes DA não tratados (DA) e tratados (DA + hOGG1). Com a exceção da comparação entre Co e DA, as demais comparações apresentaram diferenças estatisticamente significativas $(p \leq 0,01)$. (Grupo Co: $n=12$; Grupo DA: $n=12$ ) 
Dentre todos os grupos estudados, as células de pacientes controles submetidas ao tratamento com a enzima foram mais sensíveis, mesmo em relação ao grupo de tratamento com o peróxido de hidrogênio $\left(\mathrm{H}_{2} \mathrm{O}_{2}\right)$. Observa-se também que no teste com a hOGG1 e sob condições de tratamento com $\mathrm{H}_{2} \mathrm{O}_{2}$, os linfócitos de pacientes DA apresentaram níveis maiores de danos que o controle positivo. Uma vez que a enzima hOGG1 reconhece e cliva os sítios que apresentam produtos de oxidação na molécula do DNA, os resultados sugerem que uma grande parte dos danos gerados nas células de ambos os grupos experimentais deve-se aos danos oxidativos, embora tenha sido demonstrado que os pacientes DA apresentam baixos níveis de dano relativamente aos controles (Figura 2).

Embora tenham sido observadas mudanças nos resultados sob condições de tratamento com a enzima, principalmente no grupo controle, tais danos não foram tão drásticos, uma vez que o maior índice obtido foi inferior a 13\% de DNA na cauda do cometa.

Embora os valores obtidos para o controle positivo (tratamento com $\mathrm{H}_{2} \mathrm{O}_{2}$ ) tenham sido relativamente baixos, em termos de produção de danos no DNA, a análise das amostras de ambos os grupos mostrou a eficiência do método no sentido de detectar a geração de danos no DNA.

\section{Expressão gênica por qRT-PCR em Tempo Real}

As amostras de RNA total obtidas dos linfócitos de indivíduos controles e pacientes DA foram submetidas à eletroforese em gel de agarose desnaturante $(1,5 \%)$ para a avaliação da sua integridade (figura 3). Foi também avaliada a qualidade dos produtos obtidos nas reações de RT-PCR, utilizando-se o par de primers para actina $\beta$ como controle endógeno (figura 4).

Um conjunto de 20 genes foi avaliado quanto à expressão gênica transcricional em amostras de pacientes DA e controles. Foram determinados os níveis de expressão para os genes potencialmente envolvidos na patogênese de Alzheimer, principalmente os relacionados às vias de sinalização de danos, reparo e particularmente alguns genes descritos como relacionados à doença (tabela 3 e figura 5). Com a exceção de APOE (induzido) e DUSP1 (inalterado), todos os demais genes mostraram um perfil de repressão da transcrição.

O gene $A P O E$, cuja função se relaciona principalmente ao transporte de colesterol e apresenta alguma associação com a doença de Alzheimer, mostrou um fold-change (FC) de cerca de 0,51 , sendo que DUSP1, que codifica uma fosfatase envolvida na resposta ao estresse ambiental, praticamente não foi modulado, apresentando $\mathrm{FC}=-0,05$. 
A

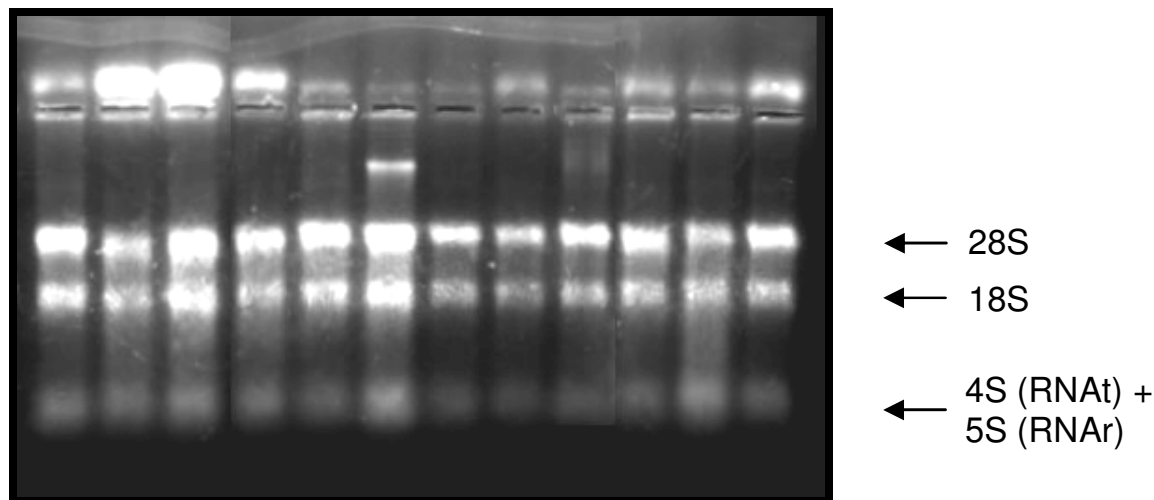

B

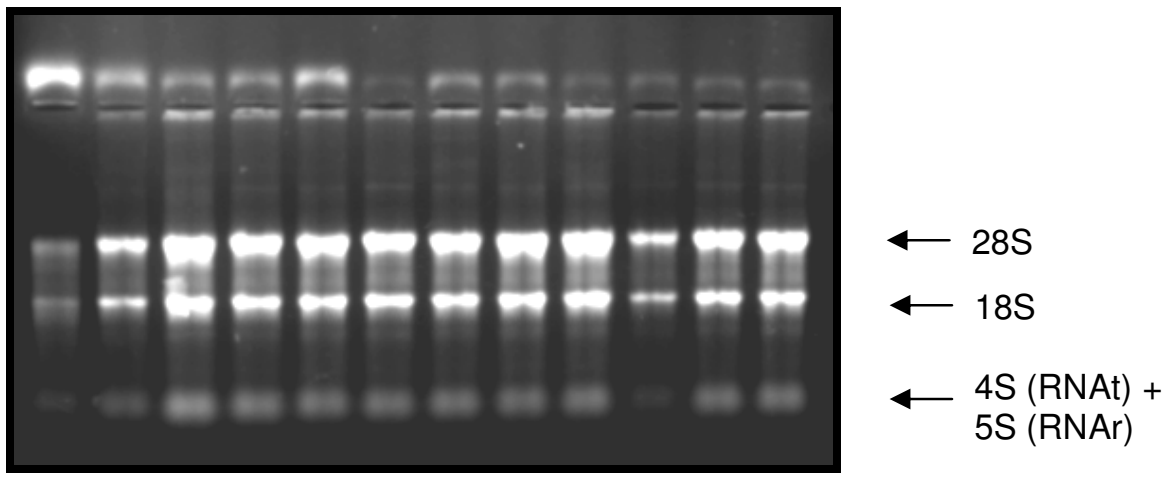

Figura 3: Avaliação da integridade das amostras de RNA total. Eletroforese em gel de agarose $1,5 \%$, evidenciando o fracionamento do RNA total das amostras dos indivíduos controles (A) e pacientes Alzheimer (B).

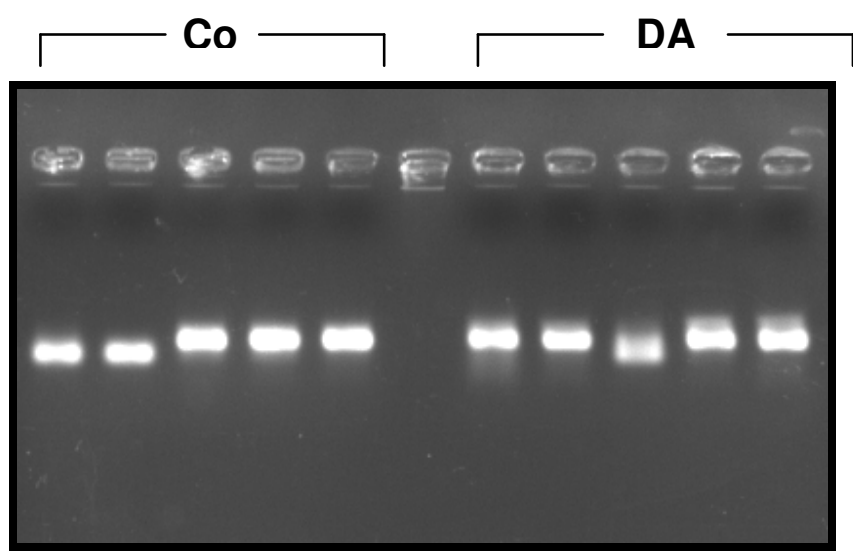

Figura 4: Avaliação da qualidade de reação da RT-PCR. Eletroforese em gel de agarose $1,5 \%$, evidenciando a amplificação do gene ACT $\beta$ (controle endógeno) nos grupos controle (Co) e Alzheimer (DA). 
Os genes restantes, sabidamente relacionados à patologia de Alzheimer, mostraram-se reprimidos, sendo eles $A D A M 17(F C=-1,38), A P P(F C=-1,84)$ e $B A C E 1$ $(F C=-3,76)$. Os demais genes também apresentaram um padrão similar. Entre os participantes na percepção e sinalização de danos, notou-se a repressão de $A T M(F C=$ 5,94), ATR (FC = -3,64), TREX1 (ATRIP) (FC = -1,86), PRKDC (FC = -1,84), RAD17 (FC $=-1,84)$ e dos genes cujos produtos formam o complexo 9-1-1: RAD9 (FC = -0,95), HUS1 $(\mathrm{FC}=-1,48)$ e $R A D 1(\mathrm{FC}=-0,63)$.

Com o intuito de tentar estabelecer alguma relação nos padrões de expressão entre genes sinalizadores e de reparo, foram avaliados também os perfis de expressão de alguns envolvidos em certas vias de reparo, tais como o APEX1 (FC = -1,76), OGG1 $(\mathrm{FC}=-0,95), \mathrm{FEN1}(\mathrm{FC}=-1,22), \mathrm{FANCG}(\mathrm{FC}=-3,15)$, ERCC1 $(\mathrm{FC}=-0,97)$, ERCC3 (FC $=-1,30)$ e $E R C C 6(F C=-3,73)$ (tabela 3 e figura 5$)$.

Nessa análise nota-se que a expressão de vários genes é sensivelmente diferente nos pacientes DA em comparação aos indivíduos controles, particularmente para os genes BACE1, ATM, ATR, FANCG e ERCC6, os quais mostraram um perfil de repressão mais intenso, numa razão superior a 3 vezes nos pacientes. Ao contrário, alguns genes mostraram um menor grau de repressão, com $\mathrm{FC}<-1,5$, como ADAM17, OGG1, FEN1, ERCC1, ERCC3, RAD9 e RAD1.

\section{Perfis de expressão gênica por microarranjos de cDNA}

Nos experimentos de microarranjos, os perfis de expressão de 4224 genes foram avaliados simultaneamente nas amostras provenientes de linfócitos de sangue periférico de pacientes com Alzheimer e indivíduos controles normais. Nesse ensaio, foram analisados 8 indivíduos de cada grupo.

Para caracterizar os genes diferencialmente expressos para ambos os grupos estudados, os valores correspondentes aos sinais de hibridação foram normalizados, sendo posteriormente submetidos à análise estatística pelo método SAM. Este apontou os genes significativamente modulados entre os dois grupos experimentais, para FDR $\leq$ 0,061 (figura 6). Foram encontrados 43 genes significativamente expressos, sendo 41 induzidos e apenas 2 reprimidos, em pacientes DA em comparação ao grupo controle (Figura 7). A identidade desses genes, assim como as suas funções (apenas para os genes conhecidos) estão representadas na tabela 4. Contudo, os genes modulados não apresentaram altos níveis de modulação transcricional, uma vez que a magnitude de 


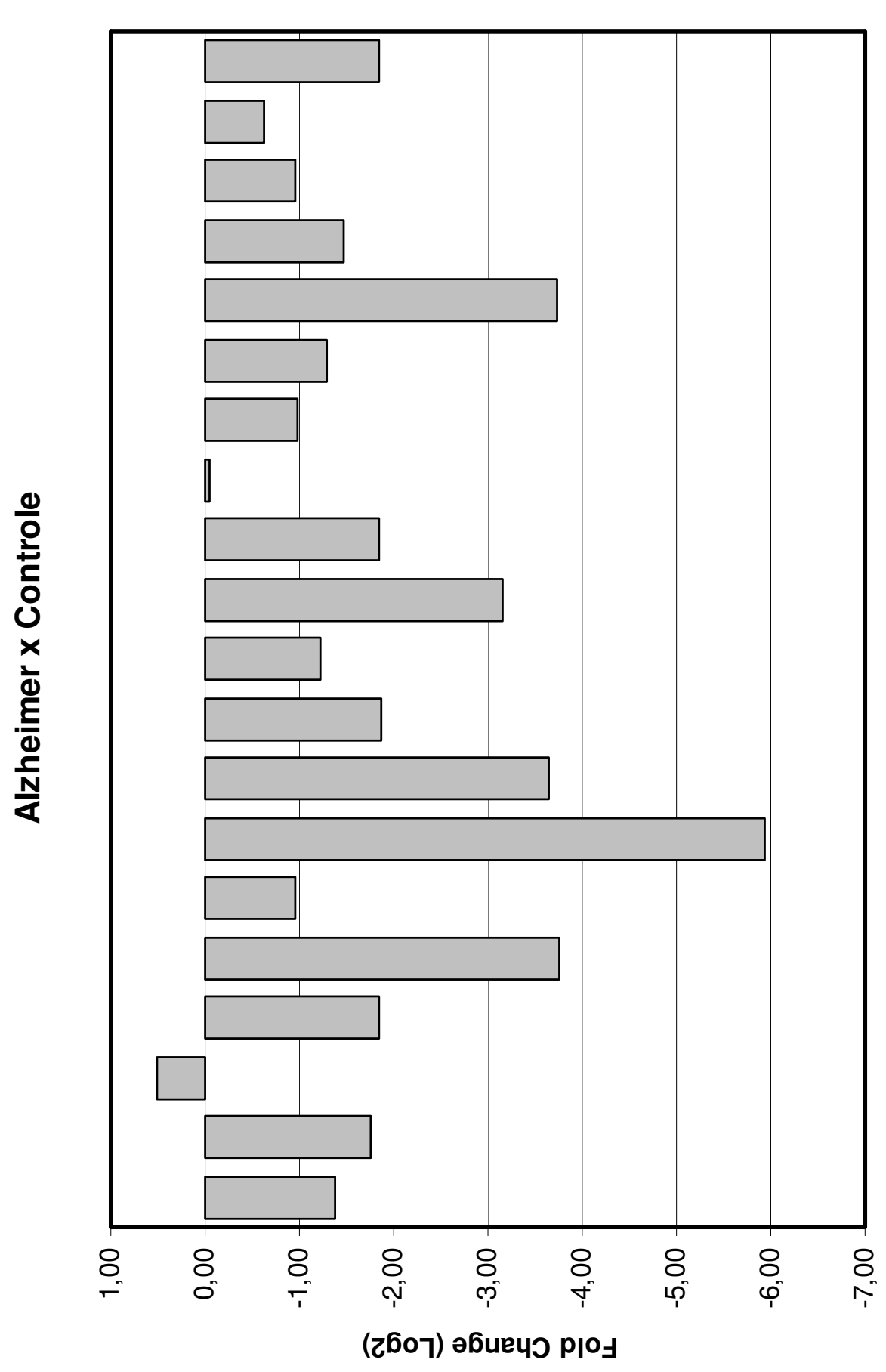

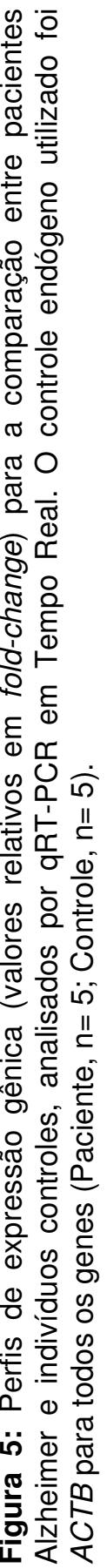


Tabela 3: Resultados da análise de expressão gênica analisada por qPCR em Tempo Real, ilustrados pelos valores de fold-change (em base $\log _{2}$ ), em amostras de RNA obtidas de pacientes DA e controles (utilizou-se o gene ACTB como controle endógeno).

\begin{tabular}{|c|c|c|}
\hline Símbolo & Nome & |Fold-change \\
\hline ACTB & Actin, beta & -1 \\
\hline ADAM17 & $\begin{array}{l}\text { ADAM metallopeptidase domain } 17 \text { (tumor necrosis } \\
\text { factor, alpha, converting enzyme) }\end{array}$ & $-1,38$ \\
\hline $\begin{array}{l}\text { APEX } 1 \\
\text { APOE }\end{array}$ & $\begin{array}{l}\text { APEX nuclease (multifunctional DNA repair enzyme) } 1 \\
\text { Apolipoprotein E }\end{array}$ & $\begin{array}{r}-1,76 \\
0,51\end{array}$ \\
\hline APP & $\begin{array}{l}\text { Amyloid beta (A4) precursor protein (peptidase nexin-II, } \\
\text { Alzheimer disease) }\end{array}$ & $-1,84$ \\
\hline ATM & Ataxia telangiectasia mutated & $-5,94$ \\
\hline ATR & Ataxia telangiectasia and Rad3 related & $-3,64$ \\
\hline BACE1 & Beta-site APP-cleaving enzyme 1 & $-3,76$ \\
\hline DUSP1 & $\begin{array}{l}\text { Dual specificity phosphatase } 1 \\
\text { Excision repair cross-complementing rodent repair }\end{array}$ & $-0,05$ \\
\hline ERCC1 & $\begin{array}{l}\text { deficiency, complementation group } 1 \text { (includes } \\
\text { overlapping antisense sequence) }\end{array}$ & $-0,97$ \\
\hline ERCC3 & $\begin{array}{l}\text { Excision repair cross-complementing rodent repair } \\
\text { deficiency, complementation group } 3 \text { (xeroderma } \\
\text { pigmentosum group B complementing) }\end{array}$ & $-1,30$ \\
\hline ERCC6 & $\begin{array}{l}\text { Excision repair cross-complementing rodent repair } \\
\text { deficiency, complementation group } 6\end{array}$ & $-3,73$ \\
\hline FANCG & Fanconi anemia, complementation group $\mathrm{G}$ & $-3,15$ \\
\hline FEN1 & Flap structure-specific endonuclease 1 & $-1,22$ \\
\hline HUS1 & HUS1 checkpoint homolog (S. pombe) & $-1,48$ \\
\hline OGG1 & 8-oxoguanine DNA glycosylase & $-0,95$ \\
\hline PRKDC & Protein kinase, DNA-activated, catalytic polypeptide & $-1,84$ \\
\hline RAD1 & RAD1 homolog (S. pombe) & $-0,63$ \\
\hline RAD17 & RAD17 homolog (S. pombe) & $-1,84$ \\
\hline RAD9 & Data not found & $-0,95$ \\
\hline TREX1 & Three prime repair exonuclease 1 & $-1,86$ \\
\hline
\end{tabular}


variação observada (expressas em fold-change) foi de 1,12 a 1,57 para os genes induzidos e de $-1,26$ a $-1,38$ para os reprimidos.

Entretanto, a distribuição dos centróides (conforme calculados a partir dos dados analisados, que representam os valores médios de expressão juntamente com os valores respectivos de desvio-padrão), variou pouco, o que aponta para uma modulação consistente, embora baixa (figura 8).

Paralelamente, foi também processada uma análise de agrupamento hierárquico dos genes, sendo utilizados os valores normalizados, obtidos de cada duplicata experimental, para aumentar o refinamento do agrupamento gênico. Para tanto, foram selecionados 187 genes a partir dos dados analisados pelo SAM (com FDR $\leq 0,176$ ).

Os resultados fornecidos pelo agrupamento hierárquico mostraram cinco grupos de genes, sendo que cada um mostra um perfil de expressão característico (figura 9). Destes, 4 agrupamentos apresentaram genes predominantemente induzidos, enquanto que apenas um mostrou um padrão de repressão, comprando-se os pacientes DA com os controles. 


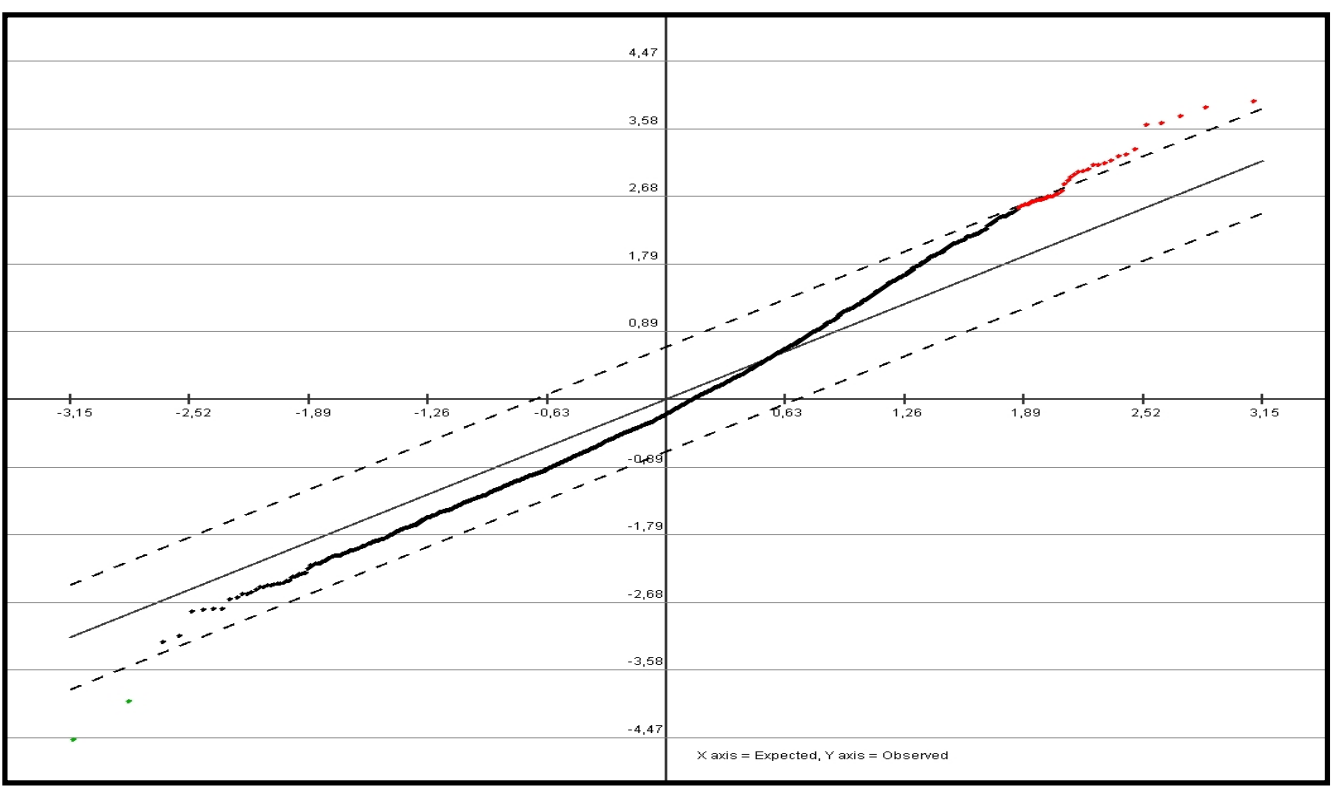

Figura 6: Genes diferencialmente expressos avaliados pelo programa SAM. Resultados das comparações entre a distância relativa observada d(i) e esperada $\mathrm{dE}$ (i) dos dados referentes à relação amostras vs pool de órgãos. A linha cheia é a região onde $\mathrm{d}(\mathrm{i})=\mathrm{dE}(\mathrm{i})$ e as linhas tracejadas são cortes a uma distância $\Delta$ da linha cheia. Os pontos abaixo (2) à linha tracejada inferior representam os genes reprimidos, enquanto que os pontos acima da linha tracejada superior (41), os induzidos (FDR $\leq 0,061)$.

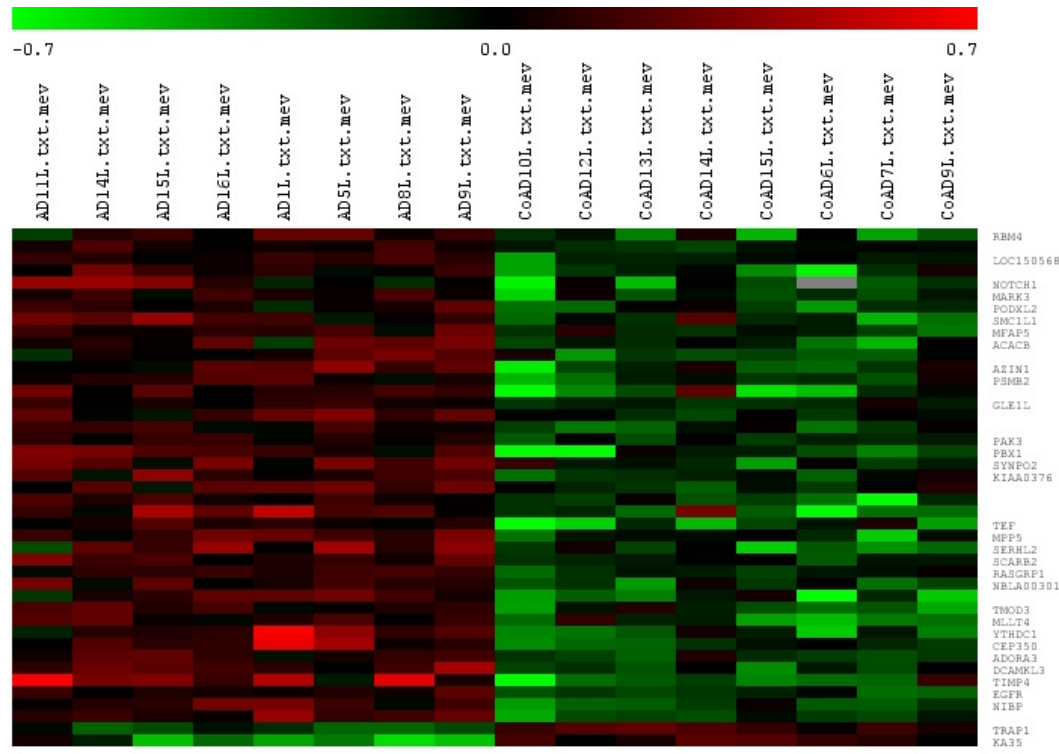

Figura 7: Agrupamento dos genes significativamente modulados, selecionados pelo método SAM (FDR= 0,061), em pacientes com Alzheimer vs controle. Os valores de expressão para cada gene estão representados de acordo com a escala apresentada no topo (Paciente, $n=8$; Controle, $n=8$ ) 
Tabela 4: Lista de genes que apresentaram uma modulação significativa na comparação entre pacientes Alzheimer e indivíduos controles. A análise estatística foi realizada pelo SAM, com um FDR $\leq 0,061$ :

\begin{tabular}{|c|c|c|c|c|c|c|}
\hline ClonelD & Símbolo & Nome do gene & $\begin{array}{l}\text { Localização } \\
\text { cromossômica }\end{array}$ & Função & FC & q-value \\
\hline 132159 & PSMB2 & $\begin{array}{l}\text { Proteasome (prosome, macropain) } \\
\text { subunit, beta type, } 2\end{array}$ & $1 p 34.2$ & & 1,199 & 6,015 \\
\hline 27806 & PBX1 & Pre-B-cell leukemia homeobox 1 & $1 \mathrm{q} 23$ & $\begin{array}{l}\text { Ativador transcricional / } \\
\text { Desenvolvimento e } \\
\text { diferenciação sexual / } \\
\text { Desenvolvimento embrionário }\end{array}$ & 1,444 & 6,015 \\
\hline 132418 & CEP350 & Centrosomal protein $350 \mathrm{kDa}$ & $1 p 36.13-q 41$ & Estrutura celular & 1,444 & 6,015 \\
\hline 137746 & ADORA3 & Adenosine $\mathrm{A} 3$ receptor & $1 \mathrm{p} 13.2$ & $\begin{array}{l}\text { Receptor de membrana / } \\
\text { Ligação com proteína G }\end{array}$ & 1,209 & 0,000 \\
\hline 141446 & RBM4 & RNA binding motif protein 4 & $11 q 13$ & Processamento do RNA & 1,237 & 5,595 \\
\hline 138496 & MFAP5 & Microfibrillar associated protein 5 & 12p13.1-p12.3 & Estrutura celular & 1,174 & 6,015 \\
\hline 155842 & ACACB & Acetyl-Coenzyme A carboxylase beta & $12 q 24.11$ & $\begin{array}{l}\text { Síntese e oxidação de ácidos } \\
\text { graxos / Atividade ligase }\end{array}$ & 1,237 & 6,015 \\
\hline 45556 & MARK3 & $\begin{array}{l}\text { MAP/microtubule affinity-regulating } \\
\text { kinase } 3\end{array}$ & $14 q 32.3$ & $\begin{array}{l}\text { Atividade cinase / Atividade } \\
\text { transferase }\end{array}$ & 1,199 & 6,015 \\
\hline 135670 & MPP5 & $\begin{array}{l}\text { Membrane protein, palmitoylated } 5 \\
\text { (MAGUK p55 subfamily member } 5 \text { ) }\end{array}$ & $14 q 23.3$ & $\begin{array}{l}\text { Receptor de membrana / } \\
\text { Supressão tumoral / } \\
\text { Transdução de sinal }\end{array}$ & 1,253 & 4,456 \\
\hline 25016 & RASGRP1 & $\begin{array}{l}\text { RAS guanyl releasing protein } 1 \\
\text { (calcium and DAG-regulated) }\end{array}$ & $15 q 15$ & $\begin{array}{l}\text { Transdução de sinal via RAS / } \\
\text { Adesão a íons de Cálcio }\end{array}$ & 1,166 & 4,718 \\
\hline 39800 & TMOD3 & Tropomodulin 3 (ubiquitous) & $15 q 21.1-q 21.2$ & Estrutura celular & 1,254 & 0,000 \\
\hline 143480 & TRAP1 & TNF receptor-associated protein 1 & $16 \mathrm{p} 13.3$ & $\begin{array}{l}\text { Dobramento de proteínas / } \\
\text { Receptor de fator de necrose } \\
\text { de tumor }\end{array}$ & $-1,264$ & 0,000 \\
\hline 139713 & KA35 & $\begin{array}{l}\text { Transcribed locus, weakly similar to } \\
\text { NP_002270.1 I hair keratin 3B [Homo } \\
\text { sapiens] }\end{array}$ & $17 q 21.2$ & & $-1,376$ & 0,000 \\
\hline 27807 & LOC150568 & Hypothetical protein LOC150568 & & & & \\
\hline 32472 & KIAA0376 & SPECC1-like & $22 q 11.23$ & Transporte de proteína & 1,202 & 6,015 \\
\hline
\end{tabular}


Continuação

\begin{tabular}{|c|c|c|c|c|c|c|}
\hline ClonelD & Símbolo & Nome do gene & $\begin{array}{l}\text { Localização } \\
\text { cromossômica }\end{array}$ & Função & FC & q-value \\
\hline 22983 & TEF & Thyrotrophic embryonic factor & $22 q 13 \mid 22 q 13.2$ & $\begin{array}{l}\text { Fator de transcrição / } \\
\text { Desenvolvmento da glândula } \\
\text { pituitária }\end{array}$ & 1,297 & 4,221 \\
\hline 138090 & SERHL2 & Serine hydrolase-like 2 & $22 q 13$ & $\begin{array}{l}\text { Atividade hidrolase / } \\
\text { Metabolismo }\end{array}$ & 1,340 & 4,718 \\
\hline 27741 & PODXL2 & $\begin{array}{l}\text { Transcribed locus, moderately similar } \\
\text { to XP_001099370.1 similar to } \\
\text { endoglycan [Macaca mulatta] }\end{array}$ & $3 q 21.3$ & & 1,192 & 6,015 \\
\hline 35092 & DCAMKL3 & Doublecortin-like kinase 3 & 3p22.2 & $\begin{array}{l}\text { Sinalização celular / } \\
\text { Desenvlvimento neuronal }\end{array}$ & 1,278 & 0,000 \\
\hline 28045 & TIMP4 & & $3 p 25$ & $\begin{array}{l}\text { Metabolismo / Oxidação de } \\
\text { componentes }\end{array}$ & 1,572 & 0,000 \\
\hline $\begin{array}{l}135766 \\
137663\end{array}$ & SYNPO2 & Hypothetical protein LOC285500 & $\begin{array}{c}4 q 34.3 \\
4 q 26\end{array}$ & Metabolismo & $\begin{array}{l}1,185 \\
1,233\end{array}$ & $\begin{array}{l}6,015 \\
6,015\end{array}$ \\
\hline 141975 & SCARB2 & $\begin{array}{l}\text { Scavenger receptor class } B \text {, member } \\
2\end{array}$ & $4 q 21.1$ & $\begin{array}{l}\text { Transporte de membrana / } \\
\text { Adesão celular }\end{array}$ & 1,188 & 4,718 \\
\hline 131656 & NBLA00301 & $\begin{array}{l}\text { Putative protein product of } \\
\text { Nbla00301 }\end{array}$ & $4 q 34.1$ & & 1,235 & 0,000 \\
\hline $\begin{array}{c}135853 \\
35380\end{array}$ & YTHDC1 & & $4 q 13.2$ & & $\begin{array}{l}1,374 \\
1,354\end{array}$ & $\begin{array}{l}0,000 \\
6,015\end{array}$ \\
\hline 131668 & & Full length insert cDNA YI09H09 & & & 1,216 & 6,015 \\
\hline 23872 & & $\begin{array}{l}\text { CDNA: FLJ22515 fis, clone } \\
\text { HRC12122, highly similar to } \\
\text { AF052101 Homo sapiens clone } \\
23872 \text { mRNA sequence }\end{array}$ & & Metabolismo & 1,242 & 3,819 \\
\hline 141797 & MLLT4 & $\begin{array}{l}\text { Myeloid/lymphoid or mixed-lineage } \\
\text { leukemia (trithorax homolog, } \\
\text { Drosophila); translocated to, } 4\end{array}$ & $6 q 27$ & $\begin{array}{l}\text { Estrutura celular / Transdução } \\
\text { de sinal / Atividade motora }\end{array}$ & 1,279 & 0,000 \\
\hline 38931 & & & & & & 6,015 \\
\hline
\end{tabular}


Continuação

\begin{tabular}{|c|c|c|c|c|c|c|}
\hline ClonelD & Símbolo & Nome do gene & $\begin{array}{l}\text { Localização } \\
\text { cromossômica }\end{array}$ & Função & FC & q-value \\
\hline 135324 & EGFR & $\begin{array}{l}\text { Epidermal growth factor receptor } \\
\text { (erythroblastic leukemia viral (v-erb- } \\
\text { b) oncogene homolog, avian) }\end{array}$ & $7 \mathrm{p} 12$ & $\begin{array}{l}\text { Proliferação e diferenciação } \\
\text { celular }\end{array}$ & 1,207 & 0,000 \\
\hline 138210 & AZIN1 & Antizyme inhibitor 1 & $8 q 22.3$ & Atividade catalítica & 1,262 & 6,015 \\
\hline 132136 & NIBP & NIK and IKK $\{$ beta $\}$ binding protein & $8 q 24.3$ & & 1,291 & 0,000 \\
\hline 51275 & NOTCH1 & $\begin{array}{l}\text { Notch homolog 1, translocation- } \\
\text { associated (Drosophila) }\end{array}$ & $9 q 34.3$ & $\begin{array}{l}\text { Fator de crescimento / } \\
\text { Diferenciação celular / } \\
\text { Transdução de sinal }\end{array}$ & 1,306 & 6,015 \\
\hline 31740 & GLE1L & $\begin{array}{l}\text { GLE1 RNA export mediator-like } \\
\text { (yeast) }\end{array}$ & $9 q 34.11$ & Transporte de RNA & 1,123 & 6,015 \\
\hline 31914 & SMC1A & $\begin{array}{l}\text { Structural maintenance of } \\
\text { chromosomes } 1 \mathrm{~A}\end{array}$ & Xp11.22-p11.21 & $\begin{array}{l}\text { Coesão de cromátides irmãs / } \\
\text { Reparo de DNA / Checkpoint } \\
\text { do ciclo celular / Resposta a } \\
\text { danos no DNA }\end{array}$ & 1,249 & 6,015 \\
\hline 132217 & PAK3 & P21 (CDKN1A)-activated kinase 3 & Xq22.3-q23 & $\begin{array}{l}\text { Transdução de sinal / } \\
\text { Desenvolvimento dendrítico e } \\
\text { plasticidade sináptica }\end{array}$ & 1,139 & 6,015 \\
\hline
\end{tabular}


A

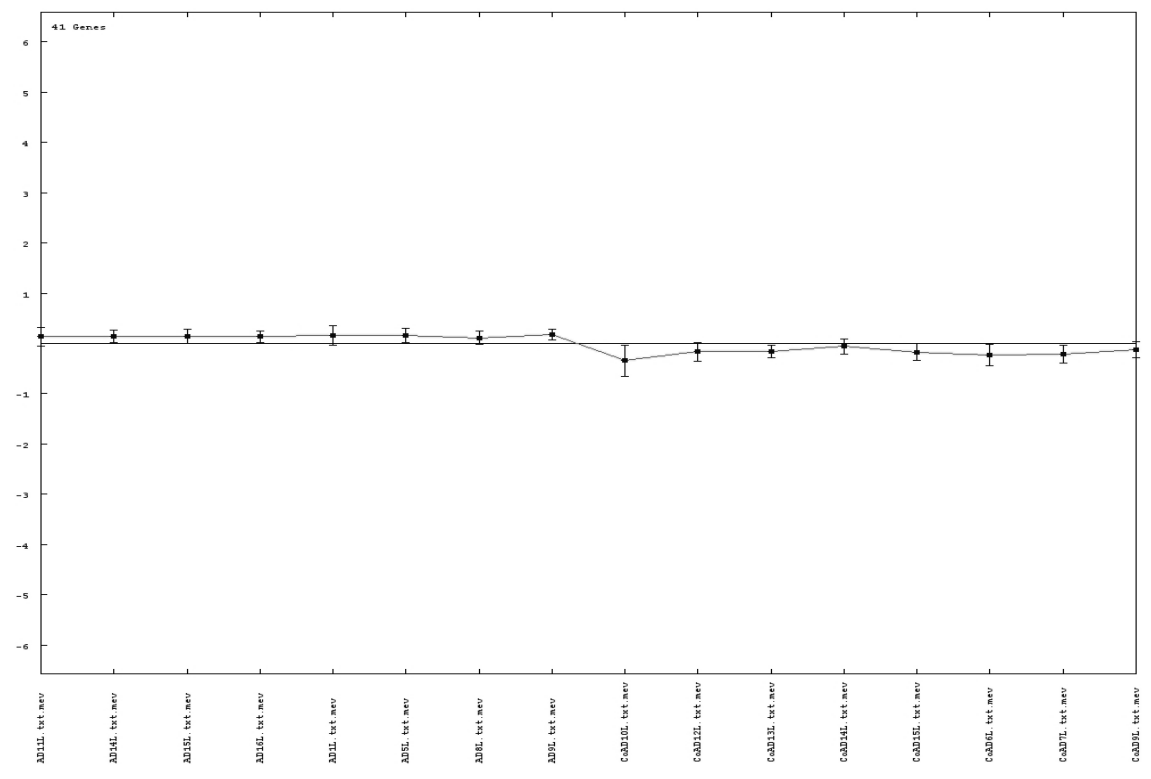

B

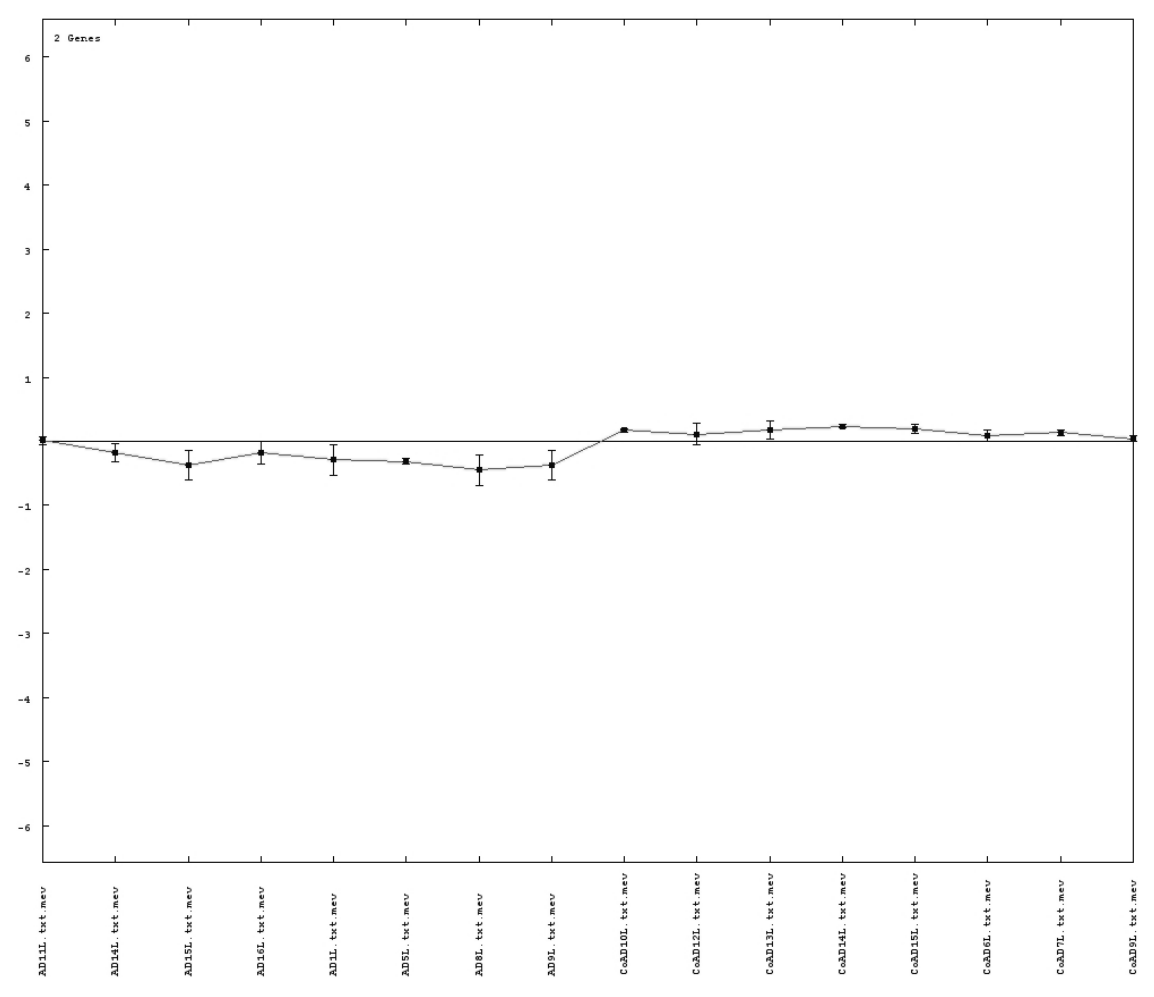

Figura 8: Centróides obtidos para os 43 genes, induzidos $(A)$ e reprimidos (B), encontrados significativamente modulados em pacientes com Alzheimer. Apesar de não apresentarem grandes variações no fold-change, os baixos desvios dos centróides indicam uma certa homogeneidade entre as amostras. 
$-0.7-0.7$

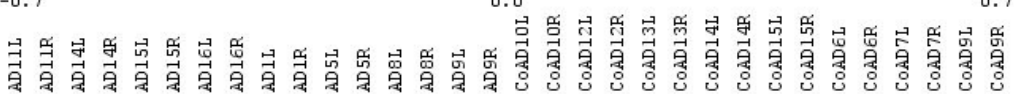
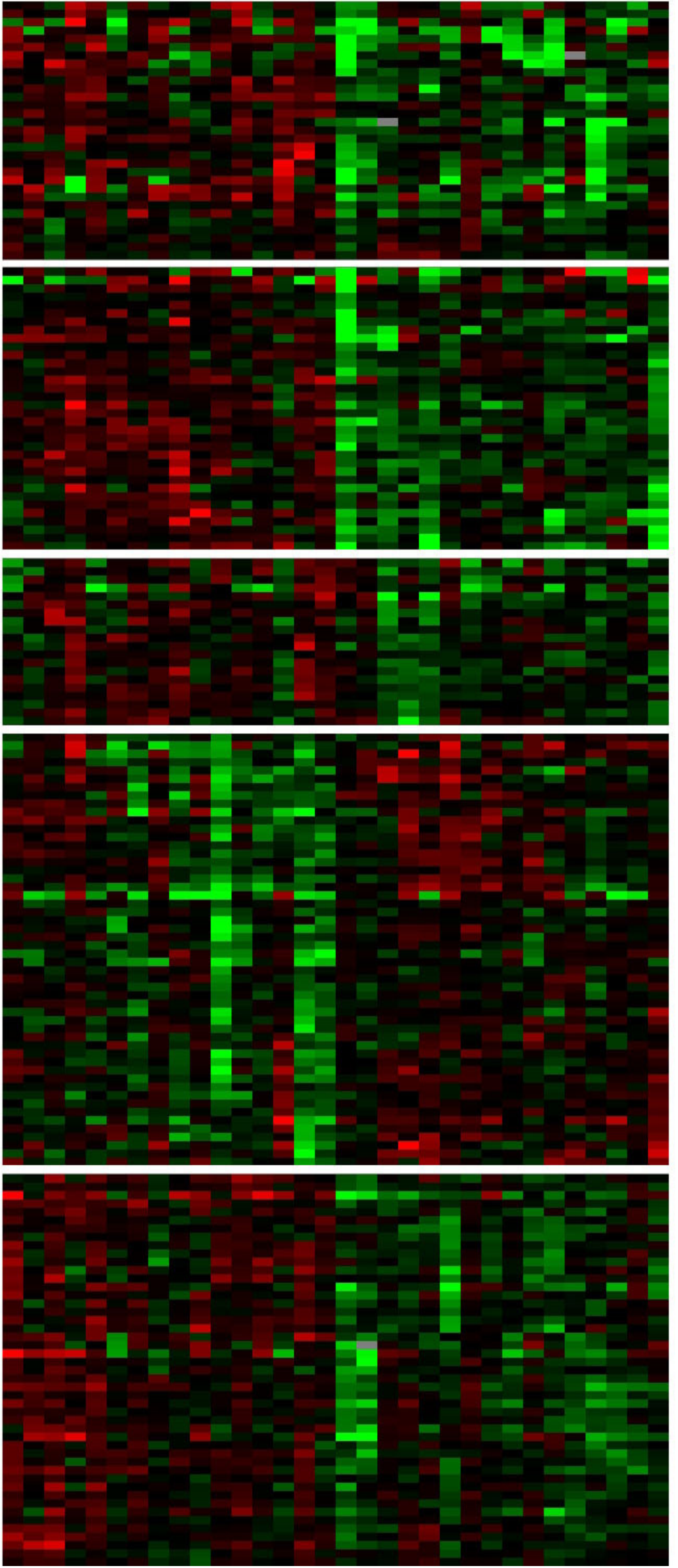

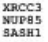

DYRK2

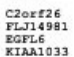

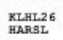

weps

zsproo

Dusp1

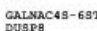

GRID2

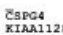

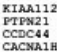

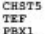

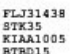

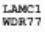

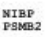

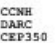

was

porec

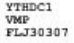

ILC26A2

KIAA1189

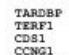

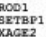

arrosa

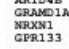

20

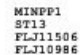

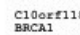

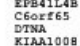

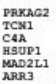

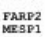

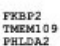

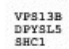

SHC1
PAPCEF1

EบT21657

Rзном1

CCHCR1
ACTY
STOOSL1

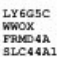

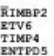

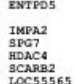

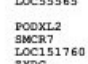

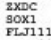

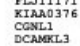

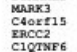

wain

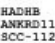

cesps

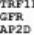

Figura 9: Agrupamento hierárquico de 187 genes, previamente selecionados pelo método SAM (FDR= 0,176 ), em pacientes com Alzheimer vs controle. Os valores de expressão para cada gene estão representados de acordo com a escala apresentada no topo, sendo que a cor vermelha indica indução e a cor verde, repressão. A cor cinza indica pontos perdidos. (Paciente, $\mathrm{n}=8$; Controle, $\mathrm{n}=$ 8 


\section{DISCUSSÃo}

\section{Dano oxidativo e genes envolvidos na condição $D A$}

Nos últimos tempos, muitas observações têm levantado questões a respeito da aparente simplicidade da via BER, particularmente no reparo in vivo do dano oxidativo no DNA. Cooper, Gowen e colegas demonstraram, por exemplo, que o reparo da timina-glicol (Tg) no DNA de células tratadas com $\mathrm{H}_{2} \mathrm{O}_{2}$ ocorre preferencialmente em regiões transcricionalmente ativas e particularmente na fita transcrita do DNA (Cooper et al., 1997; Gowen et al., 1998).

Recentemente, Cooper e colaboradores mostraram que muitas proteínas do NER também estão envolvidas no reparo da $\mathrm{Tg}$ in vivo, embora algumas de suas atividades sejam redundantes. Isso apóia a idéia que o TCR de bases oxidadas não funciona via NER e BER parece ser via preferencial (Cooper et al., 1997). Dados sobre a modulação dos genes envolvidos nessa via de reparo foram avaliados neste trabalho e os resultados são discutidos mais adiante.

Gowen e colegas mostraram ainda que BRCA1 e a sua proteína associada BAP1, as quais têm um papel importante na supressão do câncer de mama, também estão envolvidas no TCR da timina glicol (Gowen et al., 1998).

Entretanto, isso poderia ser explicado pela possibilidade de que uma variedade grande de proteínas acessórias seja necessária para o reparo in vivo dos danos no DNA induzidos por ROS, as quais devem estar envolvidas em várias etapas, desde o reconhecimento da lesão até a coordenação do processo(s) de reparo(s) competente(s).

Sabe-se atualmente que existem genes com uma estrita relação, de alguma forma, com a patogênese da doença de Alzheimer. Como é o caso do gene codificador da proteína precursora de amilóide (amyloid precursor protein - APP), onde mutações sem sentido já foram descritas (Campion et al., 1999) e os genes da presenilina 1 (PS1) e 2 (PS2). Entretanto, boa parte dessa relação parte de estudos com casos de Alzheimer familial, os quais correspondem à cerca de $5-10 \%$ dos casos diagnosticados atualmente. Por isso, devido a padrões muito complexos de herança nos casos de Alzheimer esporádico, poucas informações a respeito dessas associações gene-patogênese estão disponíveis, sendo que o gene da apolipoproteína $\mathrm{E}(A P O E)$ é o único consistentemente associado à doença (Baum et al., 2000).

Todavia, seria ilógico supor que existam genes exclusivamente relacionados ao desenvolvimento da doença, uma vez que a DA parece resultar do envelhecimento e que este, por si só, já traduz uma questão enigmática para toda a ciência, há séculos. Embora um 
considerável volume de informações já tenha sido relatado a respeito, dentre elas o declínio nas atividades metabólicas celulares, incluindo-se o acúmulo de danos oxidativos, seja por produção aumentada ROS, ou pelo funcionamento deficiente dos sistemas antioxidantes.

O presente trabalho sobre a doença de Alzheimer teve como enfoque o estudo dos fatores diretamente relacionados à doença, além de alguns outros que possam influenciá-la, como a geração de danos oxidativos, detecção ou percepção desses danos, maquinarias atuantes de reparo e num aspecto mais geral, uma assinatura genética peculiar apresentada pelos pacientes portadores de Alzheimer.

Os dados obtidos no teste do Cometa e das reações de qRT-PCR em tempo real indicaram que, de fato, os pacientes DA apresentaram características diferentes das apresentadas pelos indivíduos normais não DA.

Entre os genes relacionados mais diretamente à DA, envolvidos na produção ou deposição das placas amilóide $\beta$, observou-se uma distinta variação em seus padrões de expressão quando comparados com os controles, especificamente $A D A M 17, A P O E, A P P$ e $B A C E 1$, discutidos a seguir.

Observamos que, com a exceção da indução de $A P O E(F C=0,51)$, os genes $A D A M 17$ $(-1,38), A P P(-1,84)$ e $B A C E 1(-3,76)$, mostraram-se reprimidos em relação ao controle.

Uma vez relatado que o alelo $\varepsilon 4$ da apolipoproteína $E$ (apoE) é induzido nos pacientes DA (Strittmatter et al., 1993), muitos estudos posteriores tentaram examinar a possível relação entre os alelos de apoE e a patologia de DA (Beffert \& Poirier, 1996; Beffert \& Poirier, 1998). Muitos deles demonstraram um aumento de amilóide $\beta$ em cérebros de pacientes DA que herdavam, pelo menos, um alelo apoE4 em comparação aos pacientes sem esse, embora esta seja uma associação fraca e não encontrada em todas as áreas do cérebro e nem em todos os estudos (Beffert \& Poirier, 1996; Gearing et al., 1996; Beffert \& Poirier, 1998). Tais estudos sobre os efeitos das isoformas de apoE na agregação da $A \beta$ em culturas de neurônios e camundongos transgênicos auxiliaram na elucidação das funções das isoformas de apoE na patogênese de Alzheimer.

Os pacientes DA com pelo menos um alelo $\varepsilon 4$ tendem a apresentar uma maior deposição de amilóide do que os pacientes sem esse alelo (Beffert \& Poirier, 1996; Beffert \& Poirier, 1998). Tanto o hipocampo, como o córtex, demonstraram essa tendência. Os depósitos amilóides cerebrovascular também são aumentados em pacientes com $\varepsilon 4$ (Berg et al., 1998). Já o alelo ع2 parece ter um efeito contrário, com menos deposição de amilóides (Lippa et al., 1997). 
Interessante é notar também que a apoE4 é mais comum não só entre os pacientes DA, mas também está associada a outras complicações neurológicas graves e pacientes infartados (Nicoll et al., 1997), bem como a deterioração mais rápida em esclerose múltipla (Chapman et al., 1999). Essas evidências sugerem que, com relação à apoE3 e apoE2, a apoE4 prejudica o funcionamento neuronal ou a recuperação cerebral em resposta às lesões.

Todavia, os dados obtidos no presente trabalho apontam para uma indução no nível transcricional de apoE. Podemos especular que o primer empregado tenha amplificado a isoforma $\varepsilon 4$, ou que ela esteja em maior proporção nos pacientes DA. Em reforço à primeira hipótese, foi demonstrada uma incidência maior de $\varepsilon 4$ juntamente com a presença de certos SNP (Single Nucleotide Polymorphisms) do gene BDNF (Brain-Derived Neurotrophic Factor), também associado à doença (Huang et al., 2007). Entretanto, estudos anteriores mostraram que os níveis de apoE em camundongos expressando apoE3 e apoE4 não foram significativamente diferentes no córtex ou no fluido cerebroespinal (FCE), indicando que diferenças no nível de apoE não são responsáveis pelas diferenças patológicas observadas entre camundongos com APOE3 e APOE4 induzidos.

Ainda, pode ocorrer que, embora os níveis transcricionais desses genes tenham apresentado uma modulação positiva (ativação) com relação aos controles, alterações em nível traducional também podem ter ocorrido; por exemplo, alguma via que preferencialmente produza a isoforma $\varepsilon 4$ e favoreça o seu dobramento e/ou um splicing alternativo. Entretanto, não existe qualquer informação a esse respeito na literatura, o que aponta para novas perspectivas nessa direção.

A deposição de $A \beta$ ocorre em formas oligoméricas, profibrilares, amiloesferóides e fibrilares (Kuo et al., 1996; Lambert et al., 1998; Walsh et al., 2002). A relação de causa e efeito entre a deposição de $A \beta$ e o desenvolvimento de DA tem sido fortemente apoiada em mutações gênicas associadas a Alzheimer familial, as quais são responsáveis pela produção elevada de $A \beta 42$. A amilóide $\beta 42$ apresenta um potencial maior de agregação comparada à A $\beta 40$, sendo que atua como agente patológico primário. Vale salientar que a $A \beta$ é um peptídeo, logo é constantemente metabolizada no cérebro (Seubert et al., 1993). Assim, o estado normal dos níveis dessa proteína é determinado pelo balanço metabólico entre as atividades anabólicas e catabólicas (Selkoe, 2001). Mesmo alterações sutis nesse balanço por um longo período, poderiam resultar no surgimento das formas patogênicas da $A \beta$, influenciando $O$ progresso patológico e a incidência da doença. Por exemplo, um aumento da ordem de 1,5 na 
produção da amilóide $\beta$, causada pela maioria das mutações supracitadas, resulta em envelhecimento precoce agressivo (Sherrington et al., 1995).

Sendo assim, é de se esperar que a APP desempenhe um papel central na patogênese de DA, pois está envolvida no processo coordenado - mediado pela $\beta$-secretase (BACE) e $\gamma^{-}$ secretase - que leva à formação da amilóde $\beta$. Alternativamente, a APP pode ser levada à uma via não-amiloidogênica, executada por uma a-secretase, como a ADAM 10 (2) ou ADAM17 (Buxbaum et al., 1998; Tyler et al., 2002).

Em cérebros de pacientes DA a clivagem de APP acontece graças a proteases denominadas $\beta$ - e $\gamma$-secretases, em ambos os lados da seqüência de A $\beta$ da molécula de APP e resulta na síntese do peptídeo da amilóide $\beta$ (Haass et al., 1992; Shoji et al., 1992).

Alguns estudos sugerem que a atividade da $\beta$-secretase (BACE) aumenta em casos de Alzheimer esporádicos (Fukumoto et al., 2002; Li et al., 2004). Neles foram encontrados, tanto níveis de transcrição do mRNA, quanto a expressão de proteínas, aumentadas no córtex frontal in vivo de pacientes e viram que esses níveis não correspondiam a quaisquer mutações no gene $B A C E$. Essas observações demonstraram uma correlação positiva entre os depósitos de $A \beta$ e o aumento da atividade de BACE em pacientes DA esporádicos. A elevação de BACE deve levar a um aumento na produção de $A \beta$ e deve aumentar, por conseqüência, a deposição das placas A (Li et al., 2004).

Entretanto, os nossos resultados apontam o contrário, onde APP e BACE1 dos pacientes DA apresentaram um perfil de expressão reprimido relativo ao controle $(F C=-1,84$ e $-3,76$, respectivamente). Tais dados obtidos, assim como os demais aqui discutidos, podem ser também devido ao tipo celular estudado (linfócitos). Pacientes de Alzheimer esporádico demonstraram uma alteração na expressão de APP em plaquetas, quando comparadas com controle pareados e pacientes com demência não-DA (Di Luca et al., 1998). Di Luca e colaboradores observaram que paciente DA apresentaram uma alteração específica nos níveis das isoformas de APP, particularmente, um declínio na razão entre as isoformas maiores, de $130 \mathrm{kd}$, e menores, entre106-110, quando comparada à do grupo controle e até mesmo a outros grupos com doenças neurodegenerativas associadas à demência (Di Luca et al., 1998). Apesar disso, os autores encontraram níveis semelhantes de mRNA de um dos três principais transcritos de APP entre os grupos analisados. Os dados obtidos no presente trabalho mostram, porém, dados conflitantes com os da literatura. Pode-se sugerir que o mRNA da APP amplificado refere-se a uma das outras duas formas. 
Colciaghi e colaboradores realizaram estudos similares para a proteína BACE e encontraram duas formas específicas dessa enzima, uma de 36 kDa e outra de 57 kDa. Observaram também um declínio acentuado da primeira forma em pacientes Alzheimer, quando comparado ao grupo controle, sendo que essa atenuação havia sido perceptível mesmo em pacientes DA grau leve; por outro lado, o decréscimo da forma $36 \mathrm{kDa}$ de BACE provavelmente pode estar relacionado à uma atividade aumentada dessa enzima, inerente às suas características morfológicas (Colciaghi et al., 2004). Enquanto a forma 57 kDa de BACE deve representar a estrutura inteira de BACE, os autores sugeriram que a $36 \mathrm{kDa}$ deve estar associada a um complexo estável dos fragmentos $\mathrm{N}$ - e C-terminais, pela endoproteólise da própria BACE. Embora não se saiba o papel específico da endoproteólise de BACE, esse processo parece ser um evento fisiológico atenuador da $\beta$-secretase (Huse et al., 2003). A redução da atividade de BACE também foi verificada em tecidos postmortem (Holsinger et al., 2002; Yang et al., 2003). É possível que uma alteração na atuação conjunta entre os componentes da cascata amilóide ocorra em DA, concomitantemente ao decréscimo da atividade da $\alpha$-secretase e aumento da atividade da $\beta$-secretase (Colciaghi et al., 2004).

$O$ fato de camundongos deficientes para as proteases $\beta$ - e $\gamma$-secretases não produzirem o peptídeo $A \beta$, implica, claramente, que o complexo BACE1 e a $\gamma$-secretase é a protease amiliodogênica in vivo e, por isso, essas proteínas constituem um alvo interessante em medidas terapêuticas para pacientes DA (Haass, 2004).

Outros estudos também relataram uma expressão atenuada de ADAM10 em pacientes DA moderados e graves, implicando na baixa atividade dessa enzima (Colciaghi et al., 2004). Similarmente, verificou-se uma repressão transcricional de $A D A M 17(\mathrm{FC}=-1,38)$ em linfócitos de pacientes Alzheimer, comparados aos controles. No entanto, considerando a sua função biológica no sistema amiloidogênico, a sua repressão parece razoável - o produto gênico de $A D A M 17$, a exemplo do $A D A M 10$, também é responsável pela clivagem não-amiloidogênica de APP.

A via antiamiloidogênica começa com a APP sendo clivada pela $\alpha$-secretase, a qual corta o domínio $A \beta$, evitando assim, a geração do peptídeo. Depois da $\alpha$-secretase, o fragmento da região C-terminal da APP sofre a $\gamma$-clivagem, levando à geração do peptídeo p3 (Padovani et al., 2001), que parece ser benigno, uma vez que ele não é encontrado nas placas A $\beta$ características de DA (Lichtenthaler \& Haass, 2004). A $\alpha$-secretase é um membro da família ADAM (A Disintegrin And Metalloproteinase) de proteases (Allinson et al., 2003) e tanto 
ADAM10 (Lammich et al., 1999), quanto ADAM17/TACE (Buxbaum et al., 1998), parecem ser responsáveis pela $\alpha$-clivagem (Lichtenthaler \& Haass, 2004).

Ainda, em concordância com os dados obtidos no presente trabalho, a expressão de TACE também foi investigada em células neuronais e não-neuronais por Western blotting (Skovronsky et al., 2001). Nesse estudo, TACE mostrou-se presente nas células nervosas e foi sutilmente detectada em células gliais. Além disso, a localização imunohistoquímica apresentou expressão de TACE em populações neuronais distintas, particularmente naquelas afetadas em DA. Níveis muito baixos de TACE foram observados no cerebelo. Essas observações, portanto, permitem sugerir que a repressão de $\operatorname{ADAM17}(\mathrm{FC}=-1,38)$ verificada neste trabalho não deve ser apenas relacionada à atividade da sua enzima, mas também à sua localização.

Uma vez que a ação combinada da $\beta$ - e $\gamma$-secretase leva à formação do peptídeo $A \beta$, a inibição de suas atividades parece ser bastante promissora no tratamento e prevenção de Alzheimer (Lichtenthaler \& Haass, 2004). Todavia, o desenvolvimento de inibidores específicos para essas enzimas, os quais são capazes de ultrapassar a barreira hematoencefálica (BloodBrain Barrier - BBB) parece ser desafiador. A BACE1 parece ter uma elevada atividade de clivagem, o que torna difícil a síntese de inibidores específicos (Hong et al., 2000). A aplicabilidade da inibição da $\beta$-secretase tem sido questionada por existirem evidências de que essa protease está envolvida nos mecanismos fisiológicos de sinalização muito importantes, necessários na decisão do destino celular (Hammond et al., 2003; Shiloh, 2003). Embora esses problemas possam ser contornados, a procura por alvos alternativos parece ser mais apropriada (Lichtenthaler \& Haass, 2004).

Uma das abordagens pode ser a facilitação da clivagem de APP pela $\alpha$-secretase, uma idéia baseada em achados originais de Nitsch e colegas (Nitsch et al., 1992). Sendo que a $\alpha$ secretase cliva o domínio $A \beta$, a sua ativação pode apresentar uma vantagem dupla de não apenas evitar a formação do peptídeo $A \beta$ neurotóxico, mas também de formar o peptídeo sAPP $\alpha$ neuroprotetor (Klungland et al., 1999; Minowa et al., 2000). Essa abordagem tem recebido pouca atenção, embora seja tentadora, uma vez que BACE1 e $\alpha$-secretase competem pelo ectodomínio de APP (Arai et al., 2003). Apesar de ser um aspecto interessante, permanece a ser elucidado se a atividade das proteases ADAM em excesso podem tornar-se amiloidogênicas in vivo.

De acordo com os resultados obtidos e pelas informações obtidas a partir da literatura, a inibição de $A D A M 17, A P P$ e $B A C E 1$ (embora esta esteja associada à produção e acúmulo de $\beta$-amilóide) e a indução de $A P O E$, provavelmente devam contribuir para a progressão da DA. 
Não obstante, embora não abordada no presente trabalho, existe ainda a via catabólica da proteína amilóide $\beta$, a qual é a responsável pela degradação dessa proteína.

A redução da atividade catabólica da $A \beta$ envolvendo enzimas da sua degradação também tem sido uma causa provável do acúmulo da deposição de $A \beta$. Tanto a indução da atividade catabólica, como a inibição da anabólica deveria prevenir ou reduzir a deposição de A $\beta$ e assim, serem aplicáveis para a prevenção e terapia anti-Alzheimer (Iwata et al., 2005).

Muitas peptidases já foram propostas como degradantes da $A \beta$ : gelatinase $A$ (Yamada et al., 1995), gelatinase B (Backstrom et al., 1996), neprisilina (Howell et al., 1995), enzima degradante de insulina (IDE) (Kurochkin \& Goto, 1994), catepsina D (Hamazaki, 1996), metaloendopeptidase (Carvalho et al., 1997), fator de coagulação Xla (Saporito-Irwin \& Van Nostrand, 1995), plasmina (Van Nostrand \& Porter, 1999), proteína conversora de endotelina 1 (ECE1) (Eckman et al., 2001) e enzima conversora de angiotensina (ACE) (Hu et al., 2001).

Foi observado que a atividade de degradação da $A \beta$ acontece predominantemente via neprisilina (Takaki et al., 2000). Iwata e pesquisadores, utilizando camundongos nocauteados para a neprisilina, propuseram que a deficiência desta poderia influenciar o estado normal dos níveis de $A \beta$ no cérebro, alterando o seu metabolismo.

Uma vez que a nepresilina parece ser a maior responsável pela degradação da $A \beta$, como descrito acima, é bem provável que esteja associada com a patologia em cérebro de pacientes DA. Não obstante, a relevância patológica da neprisilina na doença de Alzheimer ainda requer um maior número de evidências e investigação, tais como avaliação da sua localização precisa no cérebro, a relação com os fatores de risco da doença e mudanças na expressão do cérebro de pacientes (Iwata et al., 2001; Iwata et al., 2005).

Possível comprometimento das maquinarias de percepção do dano e reparo de DNA em linfócitos de pacientes $D A$

Como citado anteriormente, seria pouco provável que existissem genes relacionados exclusivamente à patogênese de Alzheimer, portanto é importante ressaltar que a doença está intimamente relacionada à idade, com risco de aumento de incidência a cada ano e, por isso, seria importante avaliações sob outros pontos de vista, as outras possíveis causas possíveis no desenvolvimento da doença, como a manutenção das atividades de percepção e reparo dos danos causados por agentes oxidativos.

As ROS são formadas principalmente nas mitocôndrias durante a respiração celular. Esses produtos podem atacar todos os constituintes celulares, incluindo lipídeos, proteínas e 
ácido nucléico. A teoria dos radicais livres/estresse oxidativo no envelhecimento, como visto anteriormente, propõe que o acúmulo de danos oxidativos durante a vida de um organismo leva a um declínio gradual nos sistemas de manutenção da célula e, eventualmente, à morte (Wilson \& Bohr, 2007).

Foi sugerido que deficiências, ou uma diminuição, na atividade de reparo de dano oxidativo correlaciona-se com o envelhecimento prematuro e/ou às doenças em decorrência da idade. Na verdade, resultados apoiando a idéia de que os sistemas de manutenção do genoma constituem um fator determinante da longevidade e viabilidade celular, se originam de estudos em organismos-modelos e síndromes humanas progeróides, como as de Werner e Cockayne (Wilson \& Bohr, 2007). Muitos modelos de ratos deficientes na manutenção do genoma estão disponíveis hoje e, assim como no homem, apresentam sintomas de envelhecimento acelerado (Hasty et al., 2003; Lombard et al., 2005). Dentre os existentes, há os ratos com tricotiodistrofia (TTD) (de Boer et al., 2002). Esses animais deficientes em NER exibem propriedades associadas à idade avançada, por exemplo, osteoporose, osteosclerose, infertilidade e longevidade reduzida.

Outros exemplos de modelos com sintomas de envelhecimento precoce incluem aqueles ineficientes no reparo de DSBs (ATM e Ku80), NER (ERCC1, XPF e XPA/CSB), manutenção da telomerase e replicação do genoma mitocondrial (Lombard et al., 2005).

Evidências consideráveis indicam que falhas nas respostas ao dano no DNA estão ligadas diretamente à neurodegeneração; esse aspecto tem sido melhor elucidado no caso de doenças humanas resultantes de mutações em um dos seguintes genes: $A T M, N B S 1$, genes $X P$, da síndrome de Cockayne (CS) e Werner (WS), BLM ou FA (Rolig \& McKinnon, 2000). Pacientes com tais desordens exibem ataxia, neurodegeneração progressiva e retardo mental.

Vários estudos relatam o papel do dano oxidativo na neurodegeneração, sendo sugerido que a deficiência na via BER poderia estar associada à uma má função neuronal. Como os neurônios não se dividem, parece razoável predizer que o acúmulo de danos endógenos no DNA poderia prejudicar processos celulares essenciais, como a transcrição geral e promoção de morte celular (Nouspikel \& Hanawalt, 2002). Consistentemente, deficiência na DNA glicosilase UNG, na DNA glicosilase alquiladenina (AGG), ou APE1, levam à susceptibilidade das células neuronais à apoptose espontânea (Kruman et al., 2004). Entretanto, um estudo recente indica que a apoptose em neurônios induzida por dano oxidativo está correlacionada com o desequilíbrio de BER nas mitocôndrias (Harrison et al., 2005), mas essa questão sobre a perda neuronal por apoptose é ainda pouco elucidada. 
De acordo com os dados obtidos no presente trabalho, os pacientes DA apresentaram uma redução nos níveis trancricionais dos genes envolvido em $\mathrm{BER}$, sendo eles APEX1 (FC = 1,76), OGG1 (FC = -0,95), FEN1 $(F C=-1,22)$.

Se por um lado sabe-se que APE1 participa dos processos iniciais de BER, por outro, torna-se difícil saber qual o verdadeiro papel que essa proteína desempenha, pelo fato de não ter sido estabelecida ainda uma cultura de células humanas deficientes para tal gene. Foi sugerido que deve haver funções adicionais de APE1 não relacionadas ao processo de reparo (Evans et al., 2000). Dentre elas, a atividade Ref-1, na qual a APE1 pode atuar como um agente redutor para as formas oxidadas de alguns fatores de transcrição, restabelecendo a atividade de ligação ao DNA (Xanthoudakis et al., 1992; Walker et al., 1993). Outras funções propostas incluem a sua atuação como um co-repressor transcricional de alguns genes ou à sua atividade redutora celular para alguns componentes xenobióticos (Okazaki et al., 1994; Evans et al., 2000). Sendo assim, parece possível que uma ou mais dessas funções contribuam para o papel essencial de Ape1 em células de mamíferos, o que contrasta com a aparente dispensabilidade das endonucleases AP microbianas.

Como já discutido, algumas questões sobre o papel biológico da Ape1 surgiram a partir de diversas direções: a letalidade embrionária em camundongos Ape1 nocauteados e a aparente inviabilidade desses; a contrastante viabilidade de E. coli e S. cerevisiae; e as atividades múltiplas não relacionadas ao reparo (Evans et al., 2000). Demple e Sung observaram que uma supressão substancial de Ape1 (menos de 30\% do total normal) exerceu um efeito dramático em cada caso: inibição da proliferação celular e ativação de marcadores apoptóticos (Demple \& Sung, 2005). Em um outro experimento, os autores foram capazes de demonstrar que a supressão de Ape1 aumentou o nível de danos endógenos abásicos no DNA, por cerca de dez vezes com relação às células controles. O resultado indica que a Ape1 é necessária para lidar com a formação desses sítios, os quais poderiam acumular níveis suficientes para causar apoptose.

O acúmulo de danos abásicos a partir de fontes endógenas pode ser letal em células humanas deficientes para Ape1, mas evidentemente não em microorganismos, os quais podem sobreviver mesmo na ausência de $95 \%$ de sua atividade de endonuclease AP (Demple \& Harrison, 1994). Muitas explicações parecem possíveis para essa diferença: as quantidades muito menores de DNA em leveduras (12,5 Mb) ou em E. coli (4,6 Mb), comparadas à de humanos ( 2 x $2900 \mathrm{Mb}$ ), podem significar que muito menos lesões por célula são geradas em microrganismos; vias de reparo alternativas, como a recombinação em leveduras, podem ser 
suficientes para compensar a ausência da endonuclease AP quando a célula não é lesionada (Demple \& Harrison, 1994).

Uma vez que também foi encontrada uma modulação diferencial do gene OGG1, seria de fundamental importância o estabelecimento de uma relação entre a atividade do seu produto gênico e o acúmulo do dano oxidativo, o que levaria, a longo prazo, o desenvolvimento da patogênese de DA.

A 8-oxoG é altamente mutagênica, pois a adenina é preferencialmente incorporada à base oxidada durante a replicação pelas DNA polimerases, produzindo transversões GC para TA. Para prevenir a mutagenicidade induzida pela 8-oxoG a célula possui um mecanismo denominado de sistema GO, o qual consiste no homólogo de MutY (MYH), OGG1 e MutT (Michaels \& Miller, 1992; Hazra et al., 2001). A proteína MutT é uma fosfatase que converte especificamente a 8-oxo-dGTP do pool de nucleotídeos em 8-oxo-dGMP, para evitar que os nuleotídeos oxidados sejam incorporados ao DNA replicante. Tanto MYH, quanto OGG1 são glicosilases específicas para a 8-oxo-G e, enquanto a OGG1 remove a 8-oxoG do DNA lesionado, MYH excisa os resíduos de adenina incorporados com a 8-oxoG (Mao et al., 2007).

As mutações em OGG1 e MYH têm sido associadas ao desenvolvimento de certas doenças humanas, incluindo câncer (Boiteux \& Radicella, 2000; Parker et al., 2003). Camundongos nocauteados para OGG1 acumularam maiores níveis de lesões 8-oxoG, comparados aos controles (Klungland et al., 1999; Minowa et al., 2000) e exibiram maior índice de mutações espontâneas, especialmente quando expostos a maiores níveis de estresse oxidativo (Arai et al., 2003). Essas observações sugerem que a OGG1 atua como um fator principal na via de remoção da 8-oxoG (Mao et al., 2007).

É interessante notar também que a atividade da enzima OGG1 pode ter sido, de alguma forma, responsável pela freqüência menor de danos observada em pacientes DA, pelo teste do Cometa. Uma causa plausível seria que, apesar de pacientes e controles terem sido submetidos aos mesmos protocolos de tratamento, a atividade da enzima OGG1 seja mais eficiente nos indivíduos controle. E de acordo com o trabalho de Mao, onde extratos nucleares obtidos de cérebro de indivíduos DA foram analisados quanto ao reparo de 8-oxoG, os extratos celulares de todos os controle exibiram maiores níveis de atividade da OGG1, enquanto os extratos dos pacientes DA observados apresentaram apenas a metade da atividade glicosilase vista nos controles (Mao et al., 2007).

Outra razão possível e não necessariamente excludente da anterior seria uma interação fraca entre a OGG1 e alguma(s) proteína(s) acessórias nos pacientes DA. Embora a OGG1 (e 
as demais glicosilases) não seja essencial para o reparo do dano, muitos estudos têm registrado interações complexas de proteínas "auxiliares" (fatores não-essenciais in vitro). Muitas dessas proteínas ou suas interações específicas parecem ter uma função na coordenação precisa das etapas de BER e/ou na eficiência ou eficácia da reação de reparo (Fan et al., 2003; Wilson \& Bohr, 2007).

Sendo assim, parece que componentes adicionais são necessários para permitir o acesso das maquinarias de reparo aos sítios de danos, os quais devem ter uma associação estrita com proteínas dos nucleossomos (Mitra et al., 2001).

Embora a via BER seja, preferencialmente, a via de reparo de bases oxidadas, é importante ressaltar que as células são dotadas de outras maquinarias de reparo, específicas ou não para certos tipos de danos e ainda, com atividades sobrepostas. Por isso, é bastante provável que a falha no funcionamento dessas outras vias possam também estar relacionadas à neurodegeneração em diversas doenças, dentre elas o Alzheimer.

Duas doenças hereditárias nas quais os pacientes apresentam sinais de anormalidades neurológicas são conhecidas por serem causadas por mutações em genes participantes do NER, que afetam o reparo do DNA: XP (Xeroderma pigmentosum) e síndrome de Cockayne (SC) (Reardon et al., 1997). Estudos comprovam que alguns genes da família XP, além do reparo no DNA, também participam na transcrição, aumentando a possibilidade de que as anormalidades neurológicas em XP sejam causadas por defeitos na transcrição. Os produtos de XPB (ERCC3) e XPD são subunidades do fator de transcrição geral TFIIH (Drapkin et al., 1994). Sendo assim, seria possível que alterações neurológicas nos grupos de complementação (GC) B e D possam ser causadas por defeitos na transcrição (Reardon et al., 1997), bem como demonstrado no presente estudo, onde encontrou-se um repressão do gene ERCC3.

O reparo por excisão de nucleotídeos em mamíferos é iniciado por duas incisões, uma de cada lado da lesão, resultando na remoção do oligonucleotídeo (Huang et al., 1992). Reardon e colaboradores, a fim de saberem a função dessa via de reparo em bases oxidadas e, se essa tinha alguma associação à neurodegeneração em pacientes XP (Xeroderm pigmentosum), delinearam um experimento, onde inseriram um substrato com bases oxidadas em sítios específicos (Reardon et al., 1997). Eles viram que o reparo que ocorre para a remoção das lesões de dano oxidativo é mais lento e, dessa maneira, a função dessa via seria auxiliar na manutenção da integridade genômica, a longo prazo, em neurônios totalmente diferenciados e que, os defeitos nessa maquinaria poderiam levar à típica neurodegeneração 
encontrada nos pacientes XP e mais, essas observações apóiam outros modelos de dano no DNA em outras doenças neurodegenerativas (Robbins, 1987).

Embora etiologicamente distintas, não se pode descartar a possibilidade dessa via de reparo ter também algum tipo de relação com DA. Embora esse seja sabidamente um mecanismo que pouco participa na remoção de bases oxidadas, defeitos no seu sistema podem contribuir para o declínio cognitivo em pacientes com Alzheimer e talvez assim, a repressão trancricional dos da via NER (ERCC1, ERCC3/XPB e ERCC6/CSB), indique que a transcrição deficiente desses genes possa estar implicada na patofisiologia e, mais ainda, mostra que outras vias alternativas de reparo de danos oxidativos também são importantes na manutenção e prevenção da DA.

As vias de reparo de quebras de fita simples e duplas também parecem atuar no mecanismo de defesa contra o dano oxidativo. Uma incidência duas vezes maior de quebras de fita simples e outras lesões álcali-lábeis no DNA fora encontrada no córtex cerebral de pacientes DA versus indivíduos controles. A contribuição dos radicais livres na clivagem do DNA, processo incompleto de reparo do DNA, ou clivagem de endonucleases (como parte da cascata apoptótica) para a formação das quebras no DNA não é ainda bem conhecida (Davydov et al., 2003). Ainda, se a fragmentação do DNA se acumula durante a progressão da doença ou se ocorre durante o período de perimortem, ainda é uma questão a ser respondida.

Além das atividades reduzidas de BER nas células neuronais, já discutidas, Boerrigter e colegas demonstraram a capacidade também reduzida de reparo em fibroblastos e linfócitos humanos derivados de alguns pacientes de Alzheimer familial (Boerrigter et al., 1992).

\section{Expressão de gene sensores de danos e de genes de reparo do DNA}

No presente trabalho, foram estudados vários genes relacionados ao sensoriamento e sinalização do dano e de reparo, quanto aos perfis transcricionais em pacientes DA versus controle. Dos genes avaliados, realmente, todos se mostraram reprimidos, sendo eles: ATM $(\mathrm{FC}=-5,94), \operatorname{ATR}(\mathrm{FC}=-3,64), \operatorname{TREX1}(\operatorname{ATRIP})(\mathrm{FC}=-1,86), \operatorname{PRKDC}(\mathrm{FC}=-1,84), \operatorname{RAD} 17(\mathrm{FC}=$ -1,84), RAD9 (FC= -0,95), HUS1 ( $F C=-1,48)$ e RAD1 (FC = -0,63); e FEN1 (FC= -1,22), FANCG $(\mathrm{FC}=-3,15), \operatorname{ERCC} 1(\mathrm{FC}=-0,97), \operatorname{ERCC3}(\mathrm{XPB})(\mathrm{FC}=-1,30)$ e ERCC6 $(\mathrm{CSB})(\mathrm{FC}=-$ $3,73)$.

Os genes ATM (Ataxia telangiectasia related) e ATM (Ataxia telangiectasia mutated) compartilham seqüências homólogas e muitos substratos, porém, são ativados por estímulos diferentes. A ATM permanece inativa em células intactas sob a forma de oligômeros, com o 
domínio quinase de uma molécula ligada intermolecularmente ao domínio FAT (Focal Adhesion Target) de outra molécula (Bakkenist \& Kastan, 2003). Quando submetidas às radiações, as células induzem uma rápida autofosforilação intermolecular da serina 1981 e a dissociação do dímero, levando à ativação da sinalização da quinase ATM. A associação com o complexo Mre11-Rad50-Nbs1 também pode facilitar a monomerização e ativação de ATM (Lee \& Paull, 2005).

O mecanismo de ativação de ATR é menos conhecido e, provavelmente, deve envolver o recrutamento para sítios de DNA lesionado e interação com estruturas específicas do DNA (Byun et al., 2005; Cortez, 2005). A ATR existe em um complexo estável, com uma proteína associada, a ATRIP (ATR-interacting protein) (Cortez et al., 2001).

Mutações homozigóticas no gene da ATM pode causar a doença humana genética denominada Ataxia telangiectasia (A-T), a qual é caracterizada pela degeneração cerebelar, imunodeficiência, predisposição ao câncer e sensibilidade aguda às radiações ionizantes (Kondo et al., 2001). Os indivíduos afetados parecem ter predisposição ao desenvolvimento de leucemia prolinfocítica de células $T$, leucemia linfocítica crônica de células $B$, bem como ao câncer de cólon esporádico com instabilidade de microssatélite (Ellison \& Stillman, 2003). Além disso, a ATM parece ter uma relação estrita com outros tipos de câncer; por exemplo, estudos relativamente recentes encontraram uma ocorrência alta incomum de pacientes com câncer de mama aparentados com indivíduos A-T (Shen et al., 2000).

A ATR e ATRIP colocalizam em foci nucleares distintos após a indução de danos no DNA (Cortez et al., 2001). Esses foci nucleares são acúmulos de proteínas de checkpoint e reparo do DNA nos sítios das lesões, embora não seja conhecido o grande acúmulo das proteínas de checkpoint é necessário para o funcionamento apropriado desses mecanismos (Lisby \& Rothstein, 2004; Ball et al., 2005).

Nenhuma doença humana parece ter ligação com os defeitos em ATR, embora tenha sido relatado que a deficiência de ATR leva à mortalidade embrionária em camundongos, sugerindo que a ATR é de vital importância para o desenvolvimento (Brown \& Baltimore, 2000; de Klein et al., 2000). Não obstante, sabe-se que a modulação positiva da forma inativa de ATR exerce um efeito negativo, causando um aumento nos limiares de estímulo em resposta aos danos no DNA e falhas na ativação dos checkpoints do ciclo celular em resposta às radiações ionizantes (Cliby et al., 1998). Por outro lado, o estímulo da forma ativa de ATR pode restaurar o checkpoint da fase $S$ (defectivo em células A-T), o que sugere que a ATM e ATR têm papéis complementares nas respostas ao estresse genotóxico (Cliby et al., 1998). 
Um achado bastante curioso no presente trabalho foi a falta de modulação do gene DUSP1. Esse gene é parte integrante da família MAPK quinase (MAPKK), cujas proteínas são componentes iniciais nos processos de sinalização celular. Uma vez fosforiladas, as MAPKKs fosforilam os resíduos de treonina e tirosina das MAPKs. Uma vez ativadas as MAPKs se translocam para o núcleo e fosforilam as proteínas-alvo, incluindo muitos fatores de transcrição, dentre eles o TP53, o qual tem uma função fundamental na resposta celular ao estresse genotóxico, sendo considerado um sensor universal de resposta ao estresse genotóxico (Yang et al., 2004).

DUSP1 provavelmente tem um papel importante na resposta celular humana ao estresse ambiental, além de contribuir na regulação negativa da proliferação celular (Keyse \& Emslie, 1992). Sendo assim, a expressão semelhante desse gene entre os pacientes DA e os controles, encontrada aqui, sugere que o processo de reconhecimento dos danos presentes em pacientes Alzheimer seja independente da atividade de DUSP1, sendo reconhecidas por outras MAPK quinases, ou que as proteínas e/ou vias afetadas no desenvolvimento da doença não devem afetar os processos transcricionais de DUSP1. Ainda, há a possibilidade de que ela seja ativada normalmente e que o problema resida nas proteínas mais downstream, isto é, a DUSP1 é sintetizada normalmente, mas ela pode não ser capaz de fosforilar as proteínas subseqüentes, talvez por elas terem as funções deficientes ou por não terem sido transcritas. Além disso, embora mantenha a transcrição do mRNA em níveis normais, a sua tradução pode também ser deficiente.

Embora estudos com MAPKs (uma classe de transdutores os quais parecem ter um papel central nas respostas celulares genotóxicas) (Yang et al., 2003) tenham fornecido inúmeras informações úteis a respeito de transdutores de sinais, os sensores iniciais de danos no DNA ainda precisam ser melhor investigados. Foi proposto que alguns complexos multiprotéicos que estão envolvidos na manutenção e reparo do DNA, como os membros da família Rad, Rad1, 9, 17, 26 e Hus1, podem atuar também como sensores de danos (Lowndes \& Murguia, 2000; Roos-Mattjus et al., 2002).

Os ortólogos de Rad9, Hus1, Rad1, os quais formam o complexo Rad9-Hua1-Rad1 (91-1), são altamente conservados e participam na ativação dos checkpoints em resposta ao dano no DNA. Evidências sobre as funções dessas proteínas resultaram de estudos utilizando técnicas de modelos moleculares, as quais sugeriram que os ortólogos de Rad9, Hus1 e Rad1 se assemelham estruturalmente ao antígeno de proliferação nuclear (Proliferating Nuclear Antigen - PCNA), um complexo homotrimérico (Thelen et al., 1999; Caspari et al., 2000; 
Venclovas \& Thelen, 2000), o qual auxilia as proteínas de duplicação no DNA durante esse processo (Bell \& Dutta, 2002).

O grampo 9-1-1 interage e é carregado pela proteína de checkpoint Rad17. O complexo Rad17-RCF (Replication Factor $C$ ) carrega o 9-1-1 para o DNA in vitro (Ellison \& Stillman, 2003; Majka \& Burgers, 2003). Estudos demonstraram que o complexo 9-1-1 é um grampo que é carregado no DNA por Rad17-RCF, em resposta ao dano no DNA (Zou et al., 2002).

O estresse na replicação e outros tipos de danos no DNA levam à fosforilação e ativação da proteína quinase Chk1 pela ATR. Esta, quando ativada, tem um papel fundamental nas respostas dos checkpoints celulares, estabilizando as forquilhas de replicação bloqueadas e bloqueando a ativação das origens tardias de duplicação, além de levar as células a um bloqueio na fase G2/M. Os membros do complexo 9-1-1, juntamente com Rad17, são participantes-chave na ativação da via Chk1. Estudos demonstraram que fibroblastos de embriões de ratos (MEF) Hus1-/- e células-tronco embrionárias (ES) Rad9-/- apresentaram falhas na ativação de Chk1 (Weiss et al., 2002; Roos-Mattjus et al., 2003) e a supressão de Rad9, Hus1, ou Chk1 produziam sensibilidade fenotipicamente similares às genotoxinas (Weiss et al., 2002).

Porém, após a indução de dano no DNA, três vias independentes de Chk1 são ativadas. A primeira envolve o recrutamento de ATR-ATRIP na cromatina, em uma reação que não precisa do complexo 9-1-1 (You et al., 2002; Zou et al., 2002). Na segunda, o grampo 9-1-1 é carregado na cromatina, independentemente de Rad17 (You et al., 2002; Zou et al., 2002). E na terceira, a claspina, uma proteína de checkpoint descoberta recentemente, também é recrutada na cromatina em um processo independente de ATR e 9-1-1 (Kumagai \& Dunphy, 2000; Lee et al., 2003). O complexo 9-1-1, então ligado à cromatina, facilita a fosforilação e ativação da Chk1 mediadas por ATR (Weiss et al., 2002; Roos-Mattjus et al., 2003).

Em um estudo para avaliar se a atividade das vias de reparo em pacientes Alzheimer é comprometida, Davydov e colaboradores detectaram alterações na expressão e atividade das proteínas envolvidas no reparo de SSBs e bases oxidadas nesses indivíduos; além disso, a atividade de ligação da subunidade regulatória de Ku em DNA-PK, uma enzima sinalizadora de danos de SSB e DSB (importante proteína sinalizador no reparo NHEJ), foi reduzida em extratos nucleares do córtex médio-frontal dos pacientes (Davydov et al., 2003). 
A ATM e ATR também interagem com muitas outras proteínas que co-localizam nos sítios de dano no DNA, dentre elas a ATM participa do super complexo de proteínas denominado complexo de vigilância do genoma associado à BRCA1 (BRCA1-Associated Genome Surveillance Complex - BASC).

Embora não tenha sido avaliado, sob nenhum aspecto, a transcrição e/ou ativação de BRCA1, essa participa de muitas vias, direta ou indiretamente, associadas ao sensoriamento, transdução de sinal e ativação de muitas vias de reparo no DNA. Dessa forma, BRCA1 é discutido aqui como sendo um componente de função essencial nas vias de sinalização de danos, cujos alguns genes associados à ela, foram analisados e mencionados adiante.

A proteína BRCA1 é hiperfosforilada em resposta às lesões no DNA e ao bloqueio na sua duplicação. Evidências genéticas indicam que a BRCA1 é necessária para o TCR do dano oxidativo no DNA (Gowen et al., 1998), já mencionado, e para a recombinação homóloga em resposta às DSBs (Moynahan et al., 1999). Além disso, a BRCA1 também parece estar envolvida no controle do checkpoint na fase G2/M (Xu et al., 1999).

Evidências bioquímicas também apóiam o papel de BRCA1 no reparo do dano do DNA. Ela está associada e co-localiza com a proteína de reparo hRad51 (Scully et al., 1997). BRCA1 também se associa e é fosforilada por ATM (Cortez et al., 1999). Mais ainda, ela se associa também ao complexo RAD50-MRE11-NBS1, atuando, dessa forma, na recombinação homóloga, ligação das extremidades não-homólogas, recombinação meiótica e manutenção telomérica (Zhong et al., 1999).

Apesar disso, todas as proteínas associadas à BRCA1 também são capazes de formar sub-complexos menores e estáveis, os quais provavelmente têm funções independentes de BRCA1. A BRCA1 deve, entretanto, regular as funções desses sub-complexos para uma função de reparo especializada, ou talvez, esses complexos confiram propriedades especiais à BRCA1.

Uma característica intrigante das proteínas de reparo associadas à BRCA1, inclusive as encontradas reprimidas neste trabalho (ATM, ATR, TREX1, FANCG, RAD17 e PRKDC) é que todas elas têm a capacidade de se ligarem a estruturas anormais do DNA, como DSBs, bases mal pareadas, junções de Holliday, entre outras (Uchiumi et al., 1996; Alani et al., 1997). Portanto, essas proteínas têm o potencial de atuar como sensoras dessas estruturas. $O$ complexo RAD50-MRE11-NBS1 e a ATM, devem ser sensores de DSBs, uma vez que interagem e são reguladas pelas mesmas (Maser et al., 1997; Smith et al., 1999; Stewart et al., 1999). 
Em conjunto, os dados do presente estudo, em confronto com as informações da literatura, indicam que os processos de reparo do DNA e de percepção de danos devem estar implicados no desenvolvimento da doença de Alzheimer. A repressão transcricional de vários genes pertencentes a essas categorias, que compõem o sistema de defesa antioxidante, certamente deve contribuir para a patofisiologia da DA.

\section{Perfis de expressão gênica diferencial em pacientes $D A$}

No presente trabalho, foram analisados os perfis de expressão gênica em linfócitos de pacientes Alzheimer, comparativamente a um grupo controle, pareados quanto ao sexo, grau de escolaridade e excluindo qualquer tipo de demência. Foi obtida uma lista de 41 genes significativamente expressos em DA, sendo que com a exceção de TRAP1 e KA35, que foram reprimidos, todos os genes apresentaram um perfil de indução da transcrição; dentre eles, podem ser citados os seguintes: NOTCH1, RBM4, MARK3, SMC1L1, MFAP5, AZIN1, PSMB2, GLE1L, MPP5, PBX1 (tabela 4).

As proteínas $\mathrm{NOTCH}$ são receptores transmembrana que regulam as decisões do destino celular durante o desenvolvimento. A família Notch inclui 4 receptores, NOTCH1, NOTCH2, NOTCH3 e NOTCH4. Todos esses receptores têm domínios extracelulares contendo repetições semelhantes a múltiplos fatores de crescimento epidérmico (FCE) e uma região intracelular contendo o domínio RAM e um domínio PEST C-terminal (Das et al., 2004).

A maturação da proteína $\mathrm{NOTCH} 1$ é mediada pela convertase semelhante à furina (Chan \& Jan, 1998) durante a via secretora; a clivagem ocorre em um sítio extracelular, denominado sítio 1 (S1), após o reconhecimento da seqüência RQRR. A clivagem do sítio 2 (S2) durante processamento dessa proteína gera um peptídeo intermediário transitório, chamado NEXT (Notch extracellar truncation). NEXT se acumula quando a produção do domínio intracelular de NOTCH1 (DICN) é bloqueada por mutações de ponto ou inibidores de Y-secreteases, ou por perda da presenilina-1. A inibição de NEXT elimina a produção de DICN (Brou et al., 2000). Esses dados demonstram que a clivagem de S2 é um passo regulado por ligante na cascata proteolítica, levando à ativação de NOTCH1.

Brou e colaboradores purificaram a atividade da $\mathrm{y}$-secretase, que leva à clivagem de S2 in vitro e mostraram que ela acontece graças à ADAM17. Experimentos em células precursoras de monócitos da medula óssea ADAM17-/- , sugeriram que ADAM17 tem uma papel central na ativação da via Notch (Brou et al., 2000). 
A conexão entre Notch e as presenilinas 1 (PS1) e 2 (PS2) foi relatada por De Strooper et al, Struhl e Greenwald e Ye et al (De Strooper et al., 1999; Struhl \& Greenwald, 1999; Ye et al., 1999). Os autores mostraram que mutações de perda de função no gene da presenilina em Drosophila $s p$ levavam a um fenótipo letal semelhante à de Notch. De Strooper e colaboradores investigaram o efeito da presenilina no processamento de Notch, introduzindo uma forma constitutivamente ativa de Notch1 em fibroblastos de camundongos nocauteados para PS1 (De Strooper et al., 1999). Em experimentos anteriores, os autores indentificaram um sítio de clivagem proteolítico localizado na região transmembrana de Notch; os autores concluíram que a presenilina é necessária para a liberação do domínio intracelular de Nocth da membrana plasmática. Analisando camundongos com nocauteamento condicional da Psen1, Yu et al verificaram que a inativação da função de Psen1 no córtex cerebral de animais adultos não afetava a expressão dos genes dowstream de Notch (Yu et al., 2001).

Conforme mencionado, um dos maiores alvos das terapias de tratamento anti-Alzheimer é a y-secretase. Entretanto, essa enzima também é crítica na transdução de sinais via Notch, a qual regula o desenvolvimento e diferenciação das células renováveis em adultos (Shen et al., 2004). Esse fato levou à hipótese de que a inibição terapêutica da $\mathrm{y}$-secretase possa interferir nos processos relacionados ao Notch em adultos, principalmente na hematopoiese. Verificouse que a aplicação de inibidores de $\mathrm{y}$-secretase em culturas de timo fetal, interferia no desenvolvimento de células-T, de uma forma semelhante às observadas em culturas, nas quais a atividade de Notch1 se encontrava reduzida (Hadland et al., 2001); adicionalmente, a progressão de um estado imaturo CD4-/CD8- para um estado intermediário CD4+/CD8+ foi reprimido. Esses resultados demonstraram que a inibição farmacológica da y-secretase leva a efeitos semelhantes da perda de Notch1.

Notch1 também desempenha um papel relevante durante o desenvolvimento neuronal. O crescimento rápido dos neuritos durante a fase de desenvolvimento torna-se grandemente reduzido tão logo os neurônios amadurecem. Em estudos in vitro realizados em neurônios do córtex cerebral de camundongos, Sestan e colaboradores demonstraram que a via de contato mediado por Notch regula a capacidade dos neurônios de estenderem e elaborarem os neuritos (Sestan et al., 1999). A modulação positivia da atividade de Notch foi concomitante ao aumento no número de contatos interneuronais e parada do crescimento do neurito. Em neurônios com baixa atividade de Notch, os quais rapidamente estendem os neuritos, a indução da atividade de Notch inibiu a extensão dos neuritos ou causou a sua retração. Contrariamente, em neurônios mais maduros (os quais cessaram o seu crescimento após o 
estabelecimento de inúmeras conexões e com alta atividade de Notch), a inibição da via Notch promoveu a extensão dos neuritos. Portanto, os autores concluíram que a formação dos contatos neuronais resulta na ativação dos receptores Notch, levando à restrição do crescimento neuronal e a um subseqüente bloqueio na maturidade.

Assim, a indução do gene NOTCH1 observada no presente trabalho indica um sério comprometimento de vias de sinalização que regulam o desenvolvimento e diferenciação celular, o que pode ter contribuído para o desenvolvimento da doença nas pacientes DA analisadas.

Outro gene induzido neste trabalho e que, potencialmente, pode ter alguma associação com a DA é o MARK3. As proteínas MARK estão envolvidas na fosforilação específica das proteínas associadas ao microtúbulo da tau, MAP2 e MAP3. O gene MARK3 foi primeiramente identificado como um marcador de estresse genotóxico, visto que este sofre indução sob tratamento com agentes causadores de danos no DNA, sendo que a perda de MAPK3 também foi encontrada na carcinogênese no pâncreas (Parsa, 1988). MARK3 pode estar envolvido na regulação do ciclo celular e alterações no gene $M A P K 3$, o que pode estar relacionado ao desenvolvimento neoplásico. O gene MARK2 da mesma família mostrou-se reprimido em linfócitos irradiados in vitro com 25 e 50 cGy de raios $\gamma$ (Fachin et al, in press), indicando a sua relação com a resposta ao estresse oxidativo.

Os genes relacionados acima apresentam uma associação mais forte com as manifestações da doença de Alzheimer. Entretanto, aparentemente, os resultados obtidos pela análise de expressão por microarranjos de DNA, realizada neste trabalho, apontaram uma lista de genes cujas funções ainda não foram relacionadas à DA. Entre estes, destacam-se os genes SMC1L1, ACACB, AZIN1, PSMB2, PAK3, encontrados como diferencialmente modulados, todos induzidos.

O gene SMC1L1 participa de um complexo (coesina) responsável pela associação das cromátides irmãs durante o início da mitose. Elas se associam aos heterodímeros do complexo e os seus terminais ATPase parecem ser ligados por uma terceira subunidade, Scc1, criando um anel triangular in vivo. A clivagem proteolítica de Scc1 na anáfase leva à dissociação do complexo do cromossomo (Gruber et al., 2003).

Deardorff e colegas identificaram 14 mutações adicionais no gene SMC1A em pacientes com uma variante leve da síndrome de Cornelia de Lange, com retardo mental predominante. Análise das proteínas mutantes de SMC1A indicou que elas capazes de produzir complexos de 
coesina funcionais, entretanto, eles supuseram que essas mutações poderiam alterar as suas dinâmicas de ligação ao cromossomo (Deardorff et al., 2007).

O gene $A C A C B$, também induzido, codifica uma proteína envolvida na metabolização de ácidos graxos de cadeia longa, a ACCa. O produto da reação, malonil-CoA, o qual é gerado apenas pela ACCa, é o substrato para a síntese de ácidos graxos. Por outro lado, a ACCa é encontrada em baixos níveis em tecidos não-lipogênicos, como músculos esquelético e cardíaco, nos quais os ácidos graxos servem como fonte primária de energia. No tecido muscular, a ACC $\beta$ parece ser a necessária pelo controle da oxidação de ácidos graxos (Ha et al., 1996). O gene AZIN1 codifica a antienzima inibidora ornitina descarboxilase. A ornitina descarboxilase, uma enzima-chave na biossíntese da poliamina, é iduzida rapidamente por vários estímulos de crescimento e diferenciação celular. Em ratos, essa enzima é regulada pelo produto gênico de OAZIN (homólogo de AZIN1 em ratos), o qual inibe a atividade da ornitina descarboxilase e acelera a sua degradação proteassomal.

A observação na indução do gene PSMB2 mostrou-se interessante, uma vez que este é responsável pela tradução da proteína proteasoma 26S, a qual é um complexo protéico multisubunidade envolvido na degradação de proteínas constitutivas de vida curta, proteínas regulatórias e proteínas anormais ou mal dobradas. Ele é composto por um proteinase catalítica $20 \mathrm{~S}$ de $700 \mathrm{kD}$ e módulos regulatórios PA700. As subunidades de PA700 são divididas entre uma família de ATPAses e outra de não-ATPases. Assim, a repressão transcricional de PSMB2 em pacientes DA pode comprometer a eficiência do sistema proteassoma, o que leva a um acúmulo de proteínas alteradas. Há evidências atuais de que a causa da degeneração neuronal em DA provavelmente se relaciona ao estresse oxidativo associado à eficiência do sistema ubiquitina-proteassoma (Nakagawa \& Yokosawa, 2000).

Também foi encontrado um gene induzido, ligado à estrutura e plasticidade de células nervosas, o PAK3. As proteínas PAK são efetoras importantes que ligam as Rho GTPases à reorganização do citoesqueleto e sinalização nuclear. Essas proteínas servem como alvos para as proteínas ligadoras de GTP, Cdc42 e RAC e, parece estarem implicadas em uma gama de atividades biológicas. A proteína codificada por esse gene, forma um complexo ativado, com vários domínios que, então, cataliza uma variedade de alvos. Essa proteína pode ser necessária para o desenvolvimento dendrítico e para a rápida reorganização do citoesqueleto nas espinhas dendríticas, associadas à plasticidade sináptcia. Uma mutação de ponto nesse gene foi relacionada a um retardo mental ligado ao X não-sindrômico. 
Enfim, o advento de terapias eficazes para o tratamento de Alzheimer pressupõe a consideração de todas as vias patofisiológicas inerentes à doença. A análise de perfis de expressão gênica aberrantes no sistema nervoso central desses pacientes é impossível de ser realizada e a possibilidade da degradação post mortem do RNA e modificações na proteína podem gerar erros na interpretação dos dados derivados de amostras desse tipo. Essa má interpretação pode ser corrigida pela análise de tecidos periféricos dos pacientes DA, à luz de evidências relevantes sobre desarranjos sistêmicos nas funções-chave celulares em indivíduos afetados, incluindo alterações no metabolismo de APP, nos processos de defesa antioxidante e modificações protéicas pós-traducionais (Schipper et al., 2000; Colciaghi et al., 2004). Desta forma, o perfil de expressão de células mononucleadas do sistema sangüíneo, pode oferecer vantagens consideráveis na decifração de assinaturas aberrantes na regulação gênica em pacientes DA, pelo fato (1) dessas células serem coletadas facilmente por punção venosa; (2) do sistema nervoso central se comunicar com o sistema imune por múltiplos mecanismos (molecular, hormonal e por neurotransmissores) (Puglielli et al., 2001); (3) da expressão anormal de $A P P$, níveis alterados de enzimas antioxidantes, dano oxidativo no DNA, RNA e proteínas, desregulação da secreção de citocinas e taxas aumentadas de apoptose serem compartilhadas pelo cérebro de DA e linfócitos (Bergman et al., 2002; Mecocci et al., 2002; Li et al., 2004); e (4) pelas células do tecido sangüíneo já terem sido empregadas no diagnóstico e prognóstico de outras doenças neurológicas (Shan et al., 2003; Kalman et al., 2005).

O conceito de que essas células podem constituir uma janela para o sistema nervoso central já havia sido proposto por Percy e colegas, em uma revisão a respeito das manifestações periféricas de DA (Percy et al., 2000). Maes e colaboradores compararam os perfis de expressão gênica de $\sim 6.000$ genes em linfócitos do sangue periférico derivados de pacientes Alzheimer (grau leve) e em controles, rigorosamente pareados pelos fatores de risco da doença (Maes et al., 2006). Pelo método de microarranjos, os autores verificaram diferenças significativas nos padrões de expressão entre os pacientes DA e o grupo controle.

Assim, é provável que a indução transcricional dos vários genes mencionados, observada no estudo de expressão gênica (por microarranjos de cDNA), tenham contribuído de forma crucial para o desenvolvimento e progressão da DA nas pacientes. Visto que os genes induzidos desempenham papéis importantes ligados a processos vitais, a deficiência dos produtos gênicos leva a um sério comprometimento das vias metabólicas e da cadeia complexa de transdução de sinais em vários níveis celulares. 
Além disso, o fato de uma série de genes apresentarem perfis de indução transcricional alterados em linfócitos de pacientes DA sugerem fortemente que a modulação da transcrição de genes biomarcadores de exposição a agentes genotóxicos deve contribuir consideravelmente, ao longo da vida, na patogênese das doenças neurodegenerativas. Entretanto, tais genes deverão ainda ser pesquisados para uma melhor compreensão de seus papéis associados à DA. 


\section{CONCLUSÃo}

O controle do estado redox celular é um processo complexo governado por uma miscelânea de fatores e sistemas. Para manter a homeostase redox, as células aeróbicas desenvolveram uma série de meios de detecção de alterações nos níveis de diferentes tipos de ROS e ativação de uma rede intrincada de neutralização e reparo. O funcionamento deficiente desses sistemas celulares pode levar ao processo de neurodegeneração e a doenças associadas a ele, dentre eles a doença de Alzheimer.

Acerca disso, foi verificado no presente trabalho alterações nos níveis transcricionais de genes relacionados à percepção e reparo dos danos no DNA causados pelo estresse oxidativo, em pacientes com a doença de Alzheimer. Adicionalmente, genes associados às vias anabólica e catabólica da proteína amilóide $\beta$ também foram encontrados alterados, o que indicou uma relação forte com a patologia. Dos vinte genes analisados, apenas a $A P O E$ mostrou-se induzida, enquanto 19 genes (ADAM17, APEX1, APP, BACE1, OGG1 ATM, ATR, TREX1, FEN1, FANCG, RAD17, DUSP, ERCC1, ERCC3, ERCC6, HUS1, RAD9, RAD1, $P R K D C)$ foram reprimidos transcricionalmente.

A repressão ao nível de transcrição verificada para a maior parte desses genes indica múltiplas vias de sinalização implicadas na condição DA. Além disso, pelo fato de os genes ligados à sinalização do dano terem sido também reprimidos, supõe-se que a inibição dos níveis de transcrição dos genes de reparo (mais downstream) possa resultar da repressão dos genes sinalizadores, gerando um efeito cascata.

Embora a literatura tenha relatado níveis maiores de oxidação no DNA em pacientes DA, os dados obtidos pelo teste do Cometa mostraram o contrário; foram encontrados níveis maiores de quebras no DNA em linfócitos de mulheres do grupo controle (tratados com a enzima OGG1) em relação ao grupo das pacientes. Isso poderia ser explicado, parcialmente, pela repressão de APEX1 (avaliada em nosso trabalho), que provavelmente pode levar à indução de apoptose, ou ainda, pelo fato de componentes adicionais serem necessários para permitir uma atividade ótima da enzima.

Adicionalmente, a análise de expressão gênica por microarranjos de cDNA indicou uma série de 41 genes diferencialmente modulados $(q<0,061)$, mas para a maioria destes não há relatos na literatura sobre qualquer relação com DA. Dentre eles, o gene NOTCH1 pareceu ser um componente interessante, pois este interage diretamente com ADAM17 e está envolvido no crescimento e desenvolvimento neuronal. Além disso, o seu produto também se associa às 
proteínas catabólicas da amilóide $\beta$ (PS1 e PS2). Por essa razão, o método de microarranjos de cDNA aponta novas vias alteradas na condição DA, o que pode contribuir para futuras intervenções terapêuticas. Vários genes indicados como significativamente modulados apresentam um papel relacionado ao estresse genotóxico, tais como os genes MARK3 e SMC1. Um outro gene, PSMB2, tem a sua função ligada à tradução da proteína proteassoma 26S, complexo envolvido na degradação de proteínas (sistema ubiquitina-proteassomo).

Ainda, embora o presente estudo tenha sido realizado com amostras de linfócitos, pela facilidade com que estas podem ser coletadas, sem qualquer método invasivo, os resultados parecem indicar a validade desse estudo quando se deseja realizar um ensaio longitudinal meticuloso, que possa caracterizar o processo de falta de regulação gênica em vários estágios do transtorno cognitivo leve e na condição DA, bem como facilitar a avaliação da progressão da doença e, possivelmente, auxiliar no diagnóstico diferencial da demência no envelhecimento. 


\section{REFERÊNCIAS BIBLIOGRÁFICAS}

Abraham, R. T. (2001). "Cell cycle checkpoint signaling through the ATM and ATR kinases." Genes Dev 15(17): 2177-96.

Alani, E., S. Lee, et al. (1997). "Saccharomyces cerevisiae MSH2, a mispaired base recognition protein, also recognizes Holliday junctions in DNA." J Mol Biol 265(3): 289-301.

Allinson, T. M., E. T. Parkin, et al. (2003). "ADAMs family members as amyloid precursor protein alphasecretases." J Neurosci Res 74(3): 342-52.

Arai, T., V. P. Kelly, et al. (2003). "Cell proliferation in liver of Mmh/Ogg1-deficient mice enhances mutation frequency because of the presence of 8-hydroxyguanine in DNA." Cancer Res 63(14): 428792.

Association, A. P. (1987). Diagnostic and statistical manual of mental disorders. Washington, American Psychiatric Association.

Backstrom, J. R., G. P. Lim, et al. (1996). "Matrix metalloproteinase-9 (MMP-9) is synthesized in neurons of the human hippocampus and is capable of degrading the amyloid-beta peptide (1-40)." J Neurosci 16(24): 7910-9.

Bakkenist, C. J. and M. B. Kastan (2003). "DNA damage activates ATM through intermolecular autophosphorylation and dimer dissociation." Nature 421(6922): 499-506.

Ball, H. L., J. S. Myers, et al. (2005). "ATRIP binding to replication protein A-single-stranded DNA promotes ATR-ATRIP localization but is dispensable for Chk1 phosphorylation." Mol Biol Cell 16(5): 2372-81.

Barger, S. W., D. Horster, et al. (1995). "Tumor necrosis factors alpha and beta protect neurons against amyloid beta-peptide toxicity: evidence for involvement of a kappa B-binding factor and attenuation of peroxide and Ca2+ accumulation." Proc Natl Acad Sci U S A 92(20): 9328-32.

Barzilai, A. and K. Yamamoto (2004). "DNA damage responses to oxidative stress." DNA Repair (Amst) 3(8-9): 1109-15.

Baum, L., L. Chen, et al. (2000). "Apolipoprotein E isoforms in Alzheimer's disease pathology and etiology." Microsc Res Tech 50(4): 278-81.

Beffert, U. and J. Poirier (1996). "Apolipoprotein E, plaques, tangles and cholinergic dysfunction in Alzheimer's disease." Ann N Y Acad Sci 777: 166-74.

Beffert, U. and J. Poirier (1998). "ApoE associated with lipid has a reduced capacity to inhibit betaamyloid fibril formation." Neuroreport 9(14): 3321-3.

Behl, C. and Y. Sagara (1997). "Mechanism of amyloid beta protein induced neuronal cell death: current concepts and future perspectives." J Neural Transm Suppl 49: 125-34.

Behl, C., J. B. Davis, et al. (1994). "Hydrogen peroxide mediates amyloid beta protein toxicity." Cell 77(6): 817-27.

Bell, S. P. and A. Dutta (2002). "DNA replication in eukaryotic cells." Annu Rev Biochem 71: 333-74.

Benzi, G., A. Moretti, et al. (1995). "Are reactive oxygen species involved in Alzheimer's disease?

Berg, L., D. W. McKeel, Jr., et al. (1998). "Clinicopathologic studies in cognitively healthy aging and Alzheimer's disease: relation of histologic markers to dementia severity, age, sex, and apolipoprotein $\mathrm{E}$ genotype." Arch Neurol 55(3): 326-35.

Bergman, M., H. Salman, et al. (2002). "Are peripheral blood cells from patients with Alzheimer disease more sensitive to apoptotic stimuli?" Alzheimer Dis Assoc Disord 16(3): 156-60.

Blacker, D., L. Bertram, et al. (2003). "Results of a high-resolution genome screen of 437 Alzheimer's disease families." Hum Mol Genet 12(1): 23-32.

Boerrigter, M. E., J. Y. Wei, et al. (1992). "DNA repair and Alzheimer's disease." J Gerontol 47(6): B17784.

Boiteux, S. and J. P. Radicella (2000). "The human OGG1 gene: structure, functions, and its implication in the process of carcinogenesis." Arch Biochem Biophys 377(1): 1-8.

Brou, C., F. Logeat, et al. (2000). "A novel proteolytic cleavage involved in Notch signaling: the role of the disintegrin-metalloprotease TACE." Mol Cell 5(2): 207-16.

Brown, E. J. and D. Baltimore (2000). "ATR disruption leads to chromosomal fragmentation and early embryonic lethality." Genes Dev 14(4): 397-402.

Buxbaum, J. D., K. N. Liu, et al. (1998). "Evidence that tumor necrosis factor alpha converting enzyme is involved in regulated alpha-secretase cleavage of the Alzheimer amyloid protein precursor." J Biol Chem 273(43): 27765-7.

Byun, T. S., M. Pacek, et al. (2005). "Functional uncoupling of MCM helicase and DNA polymerase activities activates the ATR-dependent checkpoint." Genes Dev 19(9): 1040-52.

Campion, D., C. Dumanchin, et al. (1999). "Early-onset autosomal dominant Alzheimer disease: prevalence, genetic heterogeneity, and mutation spectrum." Am J Hum Genet 65(3): 664-70.

Caporaso, G. L., S. E. Gandy, et al. (1992). "Protein phosphorylation regulates secretion of Alzheimer beta/A4 amyloid precursor protein." Proc Natl Acad Sci U S A 89(7): 3055-9. 
Carvalho, K. M., M. S. Franca, et al. (1997). "A new brain metalloendopeptidase which degrades the Alzheimer beta-amyloid 1-40 peptide producing soluble fragments without neurotoxic effects." Braz $\mathrm{J}$ Med Biol Res 30(10): 1153-6.

Caspari, T., M. Dahlen, et al. (2000). "Characterization of Schizosaccharomyces pombe Hus1: a PCNArelated protein that associates with Rad1 and Rad9." Mol Cell Biol 20(4): 1254-62.

Chan, Y. M. and Y. N. Jan (1998). "Roles for proteolysis and trafficking in notch maturation and signal transduction." Cell 94(4): 423-6.

Chapman, J., C. Sylantiev, et al. (1999). "Preliminary observations on APOE epsilon4 allele and progression of disability in multiple sclerosis." Arch Neurol 56(12): 1484-7.

Charames, G. S. and B. Bapat (2003). "Genomic instability and cancer." Curr Mol Med 3(7): 589-96.

Christen, Y. (2000). "Oxidative stress and Alzheimer disease." Am J Clin Nutr 71(2): 621S-629S.

Cliby, W. A., C. J. Roberts, et al. (1998). "Overexpression of a kinase-inactive ATR protein causes sensitivity to DNA-damaging agents and defects in cell cycle checkpoints." Embo J 17(1): 159-69.

Colciaghi, F., E. Marcello, et al. (2004). "Platelet APP, ADAM 10 and BACE alterations in the early stages of Alzheimer disease." Neurology 62(3): 498-501.

Cooper, P. K., T. Nouspikel, et al. (1997). "Defective transcription-coupled repair of oxidative base damage in Cockayne syndrome patients from XP group G." Science 275(5302): 990-3.

Cortez, D. (2005). "Unwind and slow down: checkpoint activation by helicase and polymerase uncoupling." Genes Dev 19(9): 1007-12.

Cortez, D., S. Guntuku, et al. (2001). "ATR and ATRIP: partners in checkpoint signaling." Science 294(5547): 1713-6.

Cortez, D., Y. Wang, et al. (1999). "Requirement of ATM-dependent phosphorylation of brca1 in the DNA damage response to double-strand breaks." Science 286(5442): 1162-6.

Das, I., C. Craig, et al. (2004). "Notch oncoproteins depend on gamma-secretase/presenilin activity for processing and function." J Biol Chem 279(29): 30771-80.

Davydov, V., L. A. Hansen, et al. (2003). "Is DNA repair compromised in Alzheimer's disease?" Neurobiol Aging 24(7): 953-68.

de Boer, J., J. O. Andressoo, et al. (2002). "Premature aging in mice deficient in DNA repair and transcription." Science 296(5571): 1276-9.

de Klein, A., M. Muijtjens, et al. (2000). "Targeted disruption of the cell-cycle checkpoint gene ATR leads to early embryonic lethality in mice." Curr Biol 10(8): 479-82.

De Strooper, B., W. Annaert, et al. (1999). "A presenilin-1-dependent gamma-secretase-like protease mediates release of Notch intracellular domain." Nature 398(6727): 518-22.

Deardorff, M. A., M. Kaur, et al. (2007). "Mutations in cohesin complex members SMC3 and SMC1A cause a mild variant of cornelia de Lange syndrome with predominant mental retardation." Am $\mathrm{J}$ Hum Genet 80(3): 485-94.

Demple, B. and J. S. Sung (2005). "Molecular and biological roles of Ape1 protein in mammalian base excision repair." DNA Repair (Amst) 4(12): 1442-9.

Demple, B. and L. Harrison (1994). "Repair of oxidative damage to DNA: enzymology and biology." Annu Rev Biochem 63: 915-48.

Di Luca, M., L. Pastorino, et al. (1998). "Differential level of platelet amyloid beta precursor protein isoforms: an early marker for Alzheimer disease." Arch Neurol 55(9): 1195-200.

Drapkin, R., J. T. Reardon, et al. (1994). "Dual role of TFIIH in DNA excision repair and in transcription by RNA polymerase II." Nature 368(6473): 769-72.

Durocher, D. and S. P. Jackson (2001). "DNA-PK, ATM and ATR as sensors of DNA damage: variations on a theme?" Curr Opin Cell Biol 13(2): 225-31.

Dyrks, T., E. Dyrks, et al. (1992). "Amyloidogenicity of beta A4 and beta A4-bearing amyloid protein precursor fragments by metal-catalyzed oxidation." J Biol Chem 267(25): 18210-7.

Eckman, E. A., D. K. Reed, et al. (2001). "Degradation of the Alzheimer's amyloid beta peptide by endothelin-converting enzyme." J Biol Chem 276(27): 24540-8.

Ellison, V. and B. Stillman (2003). "Biochemical characterization of DNA damage checkpoint complexes: clamp loader and clamp complexes with specificity for 5' recessed DNA." PLoS Biol 1(2): E33.

Evans, A. R., M. Limp-Foster, et al. (2000). "Going APE over ref-1." Mutat Res 461(2): 83-108.

Fan, Z., P. J. Beresford, et al. (2003). "Cleaving the oxidative repair protein Ape1 enhances cell death mediated by granzyme A." Nat Immunol 4(2): 145-53.

Folstein, M. F., S. E. Folstein, et al. (1975). "'Mini-mental state". A practical method for grading the cognitive state of patients for the clinician." J Psychiatr Res 12(3): 189-98.

Fukumoto, H., B. S. Cheung, et al. (2002). "Beta-secretase protein and activity are increased in the neocortex in Alzheimer disease." Arch Neurol 59(9): 1381-9.

Gearing, M., H. Mori, et al. (1996). "Abeta-peptide length and apolipoprotein E genotype in Alzheimer's disease." Ann Neurol 39(3): 395-9.

Goodman, Y. and M. P. Mattson (1996). "Ceramide protects hippocampal neurons against excitotoxic and oxidative insults, and amyloid beta-peptide toxicity." J Neurochem 66(2): 869-72. 
Gowen, L. C., A. V. Avrutskaya, et al. (1998). "BRCA1 required for transcription-coupled repair of oxidative DNA damage." Science 281(5379): 1009-12.

Grilli, M., M. Pizzi, et al. (1996). "Neuroprotection by aspirin and sodium salicylate through blockade of NF-kappaB activation." Science 274(5291): 1383-5.

Gruber, S., C. H. Haering, et al. (2003). "Chromosomal cohesin forms a ring." Cell 112(6): 765-77.

Guo, Z., L. A. Cupples, et al. (2000). "Head injury and the risk of AD in the MIRAGE study." Neurology 54(6): 1316-23.

Ha, J., J. K. Lee, et al. (1996). "Cloning of human acetyl-CoA carboxylase-beta and its unique features." Proc Natl Acad Sci U S A 93(21): 11466-70.

Haass, C. (2004). "Take five--BACE and the gamma-secretase quartet conduct Alzheimer's amyloid betapeptide generation." Embo J 23(3): 483-8.

Haass, C., M. G. Schlossmacher, et al. (1992). "Amyloid beta-peptide is produced by cultured cells during normal metabolism." Nature 359(6393): 322-5.

Hachinski, V. C., L. D. Iliff, et al. (1975). "Cerebral blood flow in dementia." Arch Neurol 32(9): 632-7.

Hadland, B. K., N. R. Manley, et al. (2001). "Gamma -secretase inhibitors repress thymocyte development." Proc Natl Acad Sci U S A 98(13): 7487-91.

Hamazaki, H. (1996). "Cathepsin D is involved in the clearance of Alzheimer's beta-amyloid protein." FEBS Lett 396(2-3): 139-42.

Hammond, E. M., M. J. Dorie, et al. (2003). "ATR/ATM targets are phosphorylated by ATR in response to hypoxia and ATM in response to reoxygenation." J Biol Chem 278(14): 12207-13.

Harrison, J. F., S. B. Hollensworth, et al. (2005). "Oxidative stress-induced apoptosis in neurons correlates with mitochondrial DNA base excision repair pathway imbalance." Nucleic Acids Res 33(14): 4660-71.

Hasty, P., J. Campisi, et al. (2003). "Aging and genome maintenance: lessons from the mouse?" Science 299(5611): 1355-9.

Hazel, J. R. and E. E. Williams (1990). "The role of alterations in membrane lipid composition in enabling physiological adaptation of organisms to their physical environment." Prog Lipid Res 29(3): 167-227.

Hazra, T. K., J. W. Hill, et al. (2001). "Multiple DNA glycosylases for repair of 8-oxoguanine and their potential in vivo functions." Prog Nucleic Acid Res Mol Biol 68: 193-205.

Helbecque, N. and P. Amouyel (2000). "Very low density lipoprotein receptor in Alzheimer disease." Microsc Res Tech 50(4): 273-7.

Holsinger, R. M., C. A. McLean, et al. (2002). "Increased expression of the amyloid precursor betasecretase in Alzheimer's disease." Ann Neurol 51(6): 783-6.

Hong, L., G. Koelsch, et al. (2000). "Structure of the protease domain of memapsin 2 (beta-secretase) complexed with inhibitor." Science 290(5489): 150-3.

Hotoda, N., H. Koike, et al. (2002). "A secreted form of human ADAM9 has an alpha-secretase activity for APP." Biochem Biophys Res Commun 293(2): 800-5.

Howell, S., J. Nalbantoglu, et al. (1995). "Neutral endopeptidase can hydrolyze beta-amyloid(1-40) but shows no effect on beta-amyloid precursor protein metabolism." Peptides 16(4): 647-52.

$\mathrm{Hu}$, J., A. Igarashi, et al. (2001). "Angiotensin-converting enzyme degrades Alzheimer amyloid betapeptide (A beta); retards A beta aggregation, deposition, fibril formation; and inhibits cytotoxicity." J Biol Chem 276(51): 47863-8.

Huang, J. C., D. L. Svoboda, et al. (1992). "Human nucleotide excision nuclease removes thymine dimers from DNA by incising the 22nd phosphodiester bond $5^{\prime}$ and the 6th phosphodiester bond 3 ' to the photodimer." Proc Natl Acad Sci U S A 89(8): 3664-8.

Huang, R., J. Huang, et al. (2007). "Genetic variants in brain-derived neurotrophic factor associated with Alzheimer's disease." J Med Genet 44(2): e66.

Huffman, J. L., O. Sundheim, et al. (2005). "DNA base damage recognition and removal: new twists and grooves." Mutat Res 577(1-2): 55-76.

Hughes, C. P., L. Berg, et al. (1982). "A new clinical scale for the staging of dementia." Br J Psychiatry 140: $566-72$.

Huse, J. T., D. Byant, et al. (2003). "Endoproteolysis of beta-secretase (beta-site amyloid precursor protein-cleaving enzyme) within its catalytic domain. A potential mechanism for regulation." J Biol Chem 278(19): 17141-9.

Ihaka, R. G., R. (1996). "R: A language for data analysis and graphics." Journal of Computational and Graphical Statistics 5(3): 579-588.

lliakis, G., Y. Wang, et al. (2003). "DNA damage checkpoint control in cells exposed to ionizing radiation." Oncogene 22(37): 5834-47.

Iwata, N., M. Higuchi, et al. (2005). "Metabolism of amyloid-beta peptide and Alzheimer's disease." Pharmacol Ther 108(2): 129-48.

Iwata, N., S. Tsubuki, et al. (2001). "Metabolic regulation of brain Abeta by neprilysin." Science 292(5521): 1550-2. 
Jorm, A. F., A. E. Korten, et al. (1987). "The prevalence of dementia: a quantitative integration of the literature." Acta Psychiatr Scand 76(5): 465-79.

Kalman, J., K. Kitajka, et al. (2005). "Gene expression profile analysis of lymphocytes from Alzheimer's patients." Psychiatr Genet 15(1): 1-6.

Keyse, S. M. and E. A. Emslie (1992). "Oxidative stress and heat shock induce a human gene encoding a protein-tyrosine phosphatase." Nature 359(6396): 644-7.

Kim, H. S., J. H. Lee, et al. (2002). "Amyloid beta peptide induces cytochrome C release from isolated mitochondria." Neuroreport 13(15): 1989-93.

Klungland, A. and T. Lindahl (1997). "Second pathway for completion of human DNA base excisionrepair: reconstitution with purified proteins and requirement for DNase IV (FEN1)." Embo J 16(11): 3341-8.

Klungland, A., I. Rosewell, et al. (1999). "Accumulation of premutagenic DNA lesions in mice defective in removal of oxidative base damage." Proc Natl Acad Sci U S A 96(23): 13300-5.

Kohen, R. and A. Nyska (2002). "Oxidation of biological systems: oxidative stress phenomena, antioxidants, redox reactions, and methods for their quantification." Toxicol Pathol 30(6): 620-50.

Kojro, E., G. Gimpl, et al. (2001). "Low cholesterol stimulates the nonamyloidogenic pathway by its effect on the alpha -secretase ADAM 10." Proc Natl Acad Sci U S A 98(10): 5815-20.

Kondo, T., T. Wakayama, et al. (2001). "Recruitment of Mec1 and Ddc1 checkpoint proteins to doublestrand breaks through distinct mechanisms." Science 294(5543): 867-70.

Krokan, H. E., H. Nilsen, et al. (2000). "Base excision repair of DNA in mammalian cells." FEBS Lett 476(1-2): 73-7.

Kruman, II, E. Schwartz, et al. (2004). "Suppression of uracil-DNA glycosylase induces neuronal apoptosis." J Biol Chem 279(42): 43952-60.

Kumagai, A. and W. G. Dunphy (2000). "Claspin, a novel protein required for the activation of Chk1 during a DNA replication checkpoint response in Xenopus egg extracts." Mol Cell 6(4): 839-49.

Kuo, Y. M., M. R. Emmerling, et al. (1996). "Water-soluble Abeta (N-40, N-42) oligomers in normal and Alzheimer disease brains." J Biol Chem 271(8): 4077-81.

Kurochkin, I. V. and S. Goto (1994). "Alzheimer's beta-amyloid peptide specifically interacts with and is degraded by insulin degrading enzyme." FEBS Lett 345(1): 33-7.

LaDu, M. J., M. T. Falduto, et al. (1994). "Isoform-specific binding of apolipoprotein $E$ to beta-amyloid." J Biol Chem 269(38): 23403-6.

Lambert, M. P., A. K. Barlow, et al. (1998). "Diffusible, nonfibrillar ligands derived from Abeta1-42 are potent central nervous system neurotoxins." Proc Natl Acad Sci U S A 95(11): 6448-53.

Lammich, S., E. Kojro, et al. (1999). "Constitutive and regulated alpha-secretase cleavage of Alzheimer's amyloid precursor protein by a disintegrin metalloprotease." Proc Natl Acad Sci U S A 96(7): 3922-7.

Lee, J. H. and T. T. Paull (2005). "ATM activation by DNA double-strand breaks through the Mre11Rad50-Nbs1 complex." Science 308(5721): 551-4.

Lee, J., A. Kumagai, et al. (2003). "Claspin, a Chk1-regulatory protein, monitors DNA replication on chromatin independently of RPA, ATR, and Rad17." Mol Cell 11(2): 329-40.

Lendon, C. L., F. Ashall, et al. (1997). "Exploring the etiology of Alzheimer disease using molecular genetics." Jama 277(10): 825-31.

Leroy, C., C. Mann, et al. (2001). "Silent repair accounts for cell cycle specificity in the signaling of oxidative DNA lesions." Embo J 20(11): 2896-906.

Lezoualc'h, F., Y. Sagara, et al. (1998). "High constitutive NF-kappaB activity mediates resistance to oxidative stress in neuronal cells." J Neurosci 18(9): 3224-32.

Li, R., K. Lindholm, et al. (2004). "Amyloid beta peptide load is correlated with increased beta-secretase activity in sporadic Alzheimer's disease patients." Proc Natl Acad Sci U S A 101(10): 3632-7.

Lichtenthaler, S. F. and C. Haass (2004). "Amyloid at the cutting edge: activation of alpha-secretase prevents amyloidogenesis in an Alzheimer disease mouse model." J Clin Invest 113(10): 1384-7.

Lindahl, T. and R. D. Wood (1999). "Quality control by DNA repair." Science 286(5446): 1897-905.

Lippa, C. F., T. W. Smith, et al. (1997). "Apolipoprotein E-epsilon 2 and Alzheimer's disease: genotype influences pathologic phenotype." Neurology 48(2): 515-9.

Lisby, M. and R. Rothstein (2004). "DNA damage checkpoint and repair centers." Curr Opin Cell Biol 16(3): 328-34.

Livak, K. J. and T. D. Schmittgen (2001). "Analysis of relative gene expression data using real-time quantitative PCR and the 2(-Delta Delta C(T)) Method." Methods 25(4): 402-8.

Lombard, D. B., K. F. Chua, et al. (2005). "DNA repair, genome stability, and aging." Cell 120(4): 497512.

Lowndes, N. F. and J. R. Murguia (2000). "Sensing and responding to DNA damage." Curr Opin Genet Dev 10(1): 17-25.

Maes, O. C., S. Xu, et al. (2006). "Transcriptional profiling of Alzheimer blood mononuclear cells by microarray." Neurobiol Aging. 
Majka, J. and P. M. Burgers (2003). "Yeast Rad17/Mec3/Ddc1: a sliding clamp for the DNA damage checkpoint." Proc Natl Acad Sci U S A 100(5): 2249-54.

Mao, G., X. Pan, et al. (2007). "Identification and characterization of OGG1 mutations in patients with Alzheimer's disease." Nucleic Acids Res 35(8): 2759-66.

Maser, R. S., K. J. Monsen, et al. (1997). "hMre11 and hRad50 nuclear foci are induced during the normal cellular response to DNA double-strand breaks." Mol Cell Biol 17(10): 6087-96.

Matsumoto, Y., K. Kim, et al. (1999). "Reconstitution of proliferating cell nuclear antigen-dependent repair of apurinic/apyrimidinic sites with purified human proteins." J Biol Chem 274(47): 33703-8.

Mayeux, R., Y. Stern, et al. (1993). "The apolipoprotein epsilon 4 allele in patients with Alzheimer's disease." Ann Neurol 34(5): 752-4.

McKhann, G., D. Drachman, et al. (1984). "Clinical diagnosis of Alzheimer's disease: report of the NINCDS-ADRDA Work Group under the auspices of Department of Health and Human Services Task Force on Alzheimer's Disease." Neurology 34(7): 939-44.

Mecocci, P., M. C. Polidori, et al. (2002). "Lymphocyte oxidative DNA damage and plasma antioxidants in Alzheimer disease." Arch Neurol 59(5): 794-8.

Michaels, M. L. and J. H. Miller (1992). "The GO system protects organisms from the mutagenic effect of the spontaneous lesion 8-hydroxyguanine (7,8-dihydro-8-oxoguanine)." J Bacteriol 174(20): 6321-5.

Mills, J., D. Laurent Charest, et al. (1997). "Regulation of amyloid precursor protein catabolism involves the mitogen-activated protein kinase signal transduction pathway." J Neurosci 17(24): 9415-22.

Minowa, O., T. Arai, et al. (2000). "Mmh/Ogg1 gene inactivation results in accumulation of 8hydroxyguanine in mice." Proc Natl Acad Sci U S A 97(8): 4156-61.

Mitra, S., I. Boldogh, et al. (2001). "Complexities of the DNA base excision repair pathway for repair of oxidative DNA damage." Environ Mol Mutagen 38(2-3): 180-90.

Miyata, M. and J. D. Smith (1996). "Apolipoprotein E allele-specific antioxidant activity and effects on cytotoxicity by oxidative insults and beta-amyloid peptides." Nat Genet 14(1): 55-61.

Moreira, P. I., X. Zhu, et al. (2006). "The (un)balance between metabolic and oxidative abnormalities and cellular compensatory responses in Alzheimer disease." Mech Ageing Dev.

Moynahan, M. E., J. W. Chiu, et al. (1999). "Brca1 controls homology-directed DNA repair." Mol Cell 4(4): 511-8.

Nakagawa, K. and H. Yokosawa (2000). "Degradation of transcription factor IRF-1 by the ubiquitinproteasome pathway. The C-terminal region governs the protein stability." Eur J Biochem 267(6): 16806.

Naslund, J., A. Schierhorn, et al. (1994). "Relative abundance of Alzheimer A beta amyloid peptide variants in Alzheimer disease and normal aging." Proc Natl Acad Sci U S A 91(18): 8378-82.

Nelms, B. E., R. S. Maser, et al. (1998). "In situ visualization of DNA double-strand break repair in human fibroblasts." Science 280(5363): 590-2.

Nicoll, J. A., C. Burnett, et al. (1997). "High frequency of apolipoprotein E epsilon 2 allele in hemorrhage due to cerebral amyloid angiopathy." Ann Neurol 41(6): 716-21.

Nicoll, J. A., G. W. Roberts, et al. (1996). "Amyloid beta-protein, APOE genotype and head injury." Ann N Y Acad Sci 777: 271-5.

Nitsch, R. M., B. E. Slack, et al. (1992). "Release of Alzheimer amyloid precursor derivatives stimulated by activation of muscarinic acetylcholine receptors." Science 258(5080): 304-7.

Nouspikel, T. and P. C. Hanawalt (2002). "DNA repair in terminally differentiated cells." DNA Repair (Amst) 1(1): 59-75.

Okazaki, T., U. Chung, et al. (1994). "A redox factor protein, ref1, is involved in negative gene regulation by extracellular calcium." J Biol Chem 269(45): 27855-62.

Olanow, C. W. (1992). "An introduction to the free radical hypothesis in Parkinson's disease." Ann Neurol 32 Suppl: S2-9.

Otterlei, M., E. Warbrick, et al. (1999). "Post-replicative base excision repair in replication foci." Embo J 18(13): 3834-44.

Padovani, A., L. Pastorino, et al. (2001). "Amyloid precursor protein in platelets: a peripheral marker for the diagnosis of sporadic AD." Neurology 57(12): 2243-8.

Parker, A. R., R. N. O'Meally, et al. (2003). "Defective human MutY phosphorylation exists in colorectal cancer cell lines with wild-type MutY alleles." J Biol Chem 278(48): 47937-45.

Parsa, I. (1988). "Loss of a Mr 78,000 marker in chemically induced transplantable carcinomas and primary carcinoma of human pancreas." Cancer Res 48(8): 2265-72.

Paz-Elizur, T., M. Krupsky, et al. (2003). "DNA repair activity for oxidative damage and risk of lung cancer." J Natl Cancer Inst 95(17): 1312-9.

Pedrini, S., T. L. Carter, et al. (2005). "Modulation of statin-activated shedding of Alzheimer APP ectodomain by ROCK." PLoS Med 2(1): e18.

Percy, M. E., D. E. Andrews, et al. (2000). Peripheral markers of Alzheimer's disease. Totowa NJ, Human Press. 
Poirier, J. (1999). "Apolipoprotein E4, cholinergic integrity and the pharmacogenetics of Alzheimer's disease." J Psychiatry Neurosci 24(2): 147-53.

Puglielli, L., G. Konopka, et al. (2001). "Acyl-coenzyme A: cholesterol acyltransferase modulates the generation of the amyloid beta-peptide." Nat Cell Biol 3(10): 905-12.

Reardon, J. T., T. Bessho, et al. (1997). "In vitro repair of oxidative DNA damage by human nucleotide excision repair system: possible explanation for neurodegeneration in xeroderma pigmentosum patients." Proc Natl Acad Sci U S A 94(17): 9463-8.

Reardon, J. T., T. Bessho, et al. (1997). "In vitro repair of oxidative DNA damage by human nucleotide excision repair system: possible explanation for neurodegeneration in xeroderma pigmentosum patients." Proc Natl Acad Sci U S A 94(17): 9463-8.

Reiter, R. J., D. X. Tan, et al. (1994). "Melatonin as a free radical scavenger: implications for aging and age-related diseases." Ann N Y Acad Sci 719: 1-12.

Robbins, J. H. (1987). "Incorrect priority claim for the DNA-damage hypothesis." Arch Neurol 44(6): 57983.

Rolig, R. L. and P. J. McKinnon (2000). "Linking DNA damage and neurodegeneration." Trends Neurosci 23(9): 417-24.

Roos-Mattjus, P., B. T. Vroman, et al. (2002). "Genotoxin-induced Rad9-Hus1-Rad1 (9-1-1) chromatin association is an early checkpoint signaling event." J Biol Chem 277(46): 43809-12.

Roos-Mattjus, P., K. M. Hopkins, et al. (2003). "Phosphorylation of human Rad9 is required for genotoxinactivated checkpoint signaling." J Biol Chem 278(27): 24428-37.

Sagara, Y., R. Dargusch, et al. (1996). "Increased antioxidant enzyme activity in amyloid beta proteinresistant cells." J Neurosci 16(2): 497-505.

Saporito-Irwin, S. M. and W. E. Van Nostrand (1995). "Coagulation factor Xla cleaves the RHDS sequence and abolishes the cell adhesive properties of the amyloid beta-protein." J Biol Chem 270(44): 26265-9.

Saunders, A. M., W. J. Strittmatter, et al. (1993). "Association of apolipoprotein E allele epsilon 4 with late-onset familial and sporadic Alzheimer's disease." Neurology 43(8): 1467-72.

Schipper, H. M., H. Chertkow, et al. (2000). "Evaluation of heme oxygenase-1 as a systemic biological marker of sporadic AD." Neurology 54(6): 1297-304.

Scully, R., J. Chen, et al. (1997). "Association of BRCA1 with Rad51 in mitotic and meiotic cells." Cell 88(2): 265-75.

Selkoe, D. J. (2001). "Alzheimer's disease: genes, proteins, and therapy." Physiol Rev 81(2): 741-66.

Serum levels of the iron binding protein p97 are elevated in Alzheimer's disease." Neurobiol Aging 16(4): 661-74.

Sestan, N., S. Artavanis-Tsakonas, et al. (1999). "Contact-dependent inhibition of cortical neurite growth mediated by notch signaling." Science 286(5440): 741-6.

Seubert, P., T. Oltersdorf, et al. (1993). "Secretion of beta-amyloid precursor protein cleaved at the amino terminus of the beta-amyloid peptide." Nature 361(6409): 260-3.

Shan, X., H. Tashiro, et al. (2003). "The identification and characterization of oxidized RNAs in Alzheimer's disease." J Neurosci 23(12): 4913-21.

Shen, C. Y., J. C. Yu, et al. (2000). "Genome-wide search for loss of heterozygosity using laser capture microdissected tissue of breast carcinoma: an implication for mutator phenotype and breast cancer pathogenesis." Cancer Res 60(14): 3884-92.

Shen, Q., S. K. Goderie, et al. (2004). "Endothelial cells stimulate self-renewal and expand neurogenesis of neural stem cells." Science 304(5675): 1338-40.

Sherrington, R., E. I. Rogaev, et al. (1995). "Cloning of a gene bearing missense mutations in early-onset familial Alzheimer's disease." Nature 375(6534): 754-60.

Shiloh, Y. (2003). "ATM and related protein kinases: safeguarding genome integrity." Nat Rev Cancer 3(3): 155-68.

Shiloh, Y. and M. B. Kastan (2001). "ATM: genome stability, neuronal development, and cancer cross paths." Adv Cancer Res 83: 209-54.

Shoji, M., T. E. Golde, et al. (1992). "Production of the Alzheimer amyloid beta protein by normal proteolytic processing." Science 258(5079): 126-9.

Skovronsky, D. M., S. Fath, et al. (2001). "Neuronal localization of the TNFalpha converting enzyme (TACE) in brain tissue and its correlation to amyloid plaques." J Neurobiol 49(1): 40-6.

Slupphaug, G., B. Kavli, et al. (2003). "The interacting pathways for prevention and repair of oxidative DNA damage." Mutat Res 531(1-2): 231-51.

Smith, G. C., R. B. Cary, et al. (1999). "Purification and DNA binding properties of the ataxiatelangiectasia gene product ATM." Proc Natl Acad Sci U S A 96(20): 11134-9.

Smith, M. A., L. M. Sayre, et al. (1995). "Radical AGEing in Alzheimer's disease." Trends Neurosci 18(4): 172-6.

Snowdon, D. A., L. H. Greiner, et al. (1997). "Brain infarction and the clinical expression of Alzheimer disease. The Nun Study." Jama 277(10): 813-7. 
Sohal, R. S. (1993). "The free radical hypothesis of aging: an appraisal of the current status." Aging (Milano) 5(1): 3-17.

Sramek, J. J. and N. R. Cutler (1999). "Recent developments in the drug treatment of Alzheimer's disease." Drugs Aging 14(5): 359-73.

St George-Hyslop, P., D. C. McLachlan, et al. (1994). "Alzheimer's disease and possible gene interaction." Science 263(5146): 537.

Stewart, G. S., R. S. Maser, et al. (1999). "The DNA double-strand break repair gene hMRE11 is mutated in individuals with an ataxia-telangiectasia-like disorder." Cell 99(6): 577-87.

Stivers, J. T. and Y. L. Jiang (2003). "A mechanistic perspective on the chemistry of DNA repair glycosylases." Chem Rev 103(7): 2729-59.

Strittmatter, W. J., A. M. Saunders, et al. (1993). "Apolipoprotein E: high-avidity binding to beta-amyloid and increased frequency of type 4 allele in late-onset familial Alzheimer disease." Proc Natl Acad Sci U S A 90(5): 1977-81.

Struhl, G. and I. Greenwald (1999). "Presenilin is required for activity and nuclear access of Notch in Drosophila." Nature 398(6727): 522-5.

Takaki, Y., N. Iwata, et al. (2000). "Biochemical identification of the neutral endopeptidase family member responsible for the catabolism of amyloid beta peptide in the brain." J Biochem (Tokyo) 128(6): 897902.

Thelen, M. P., C. Venclovas, et al. (1999). "A sliding clamp model for the Rad1 family of cell cycle checkpoint proteins." Cell 96(6): 769-70.

Thomas, T., G. Thomas, et al. (1996). "beta-Amyloid-mediated vasoactivity and vascular endothelial damage." Nature 380(6570): 168-71.

Tomkinson, A. E., L. Chen, et al. (2001). "Completion of base excision repair by mammalian DNA ligases." Prog Nucleic Acid Res Mol Biol 68: 151-64.

Tyler, S. J., D. Dawbarn, et al. (2002). "alpha- and beta-secretase: profound changes in Alzheimer's disease." Biochem Biophys Res Commun 299(3): 373-6.

Uchiumi, F., T. Ohta, et al. (1996). "Replication factor C recognizes 5'-phosphate ends of telomeres." Biochem Biophys Res Commun 229(1): 310-5.

van Duijn, C. M., D. Clayton, et al. (1991). "Familial aggregation of Alzheimer's disease and related disorders: a collaborative re-analysis of case-control studies. EURODEM Risk Factors Research Group." Int J Epidemiol 20 Suppl 2: S13-20.

Van Nostrand, W. E. and M. Porter (1999). "Plasmin cleavage of the amyloid beta-protein: alteration of secondary structure and stimulation of tissue plasminogen activator activity." Biochemistry 38(35): 11570-6.

Venclovas, C. and M. P. Thelen (2000). "Structure-based predictions of Rad1, Rad9, Hus1 and Rad17 participation in sliding clamp and clamp-loading complexes." Nucleic Acids Res 28(13): 2481-93.

Walker, L. J., C. N. Robson, et al. (1993). "Identification of residues in the human DNA repair enzyme HAP1 (Ref-1) that are essential for redox regulation of Jun DNA binding." Mol Cell Biol 13(9): 5370-6.

Walsh, D. M., I. Klyubin, et al. (2002). "Naturally secreted oligomers of amyloid beta protein potently inhibit hippocampal long-term potentiation in vivo." Nature 416(6880): 535-9.

Weiss, R. S., S. Matsuoka, et al. (2002). "Hus1 acts upstream of chk1 in a mammalian DNA damage response pathway." Curr Biol 12(1): 73-7.

Wilson, D. M., 3rd and D. Barsky (2001). "The major human abasic endonuclease: formation, consequences and repair of abasic lesions in DNA." Mutat Res 485(4): 283-307.

Wilson, D. M., 3rd and V. A. Bohr (2007). "The mechanics of base excision repair, and its relationship to aging and disease." DNA Repair (Amst) 6(4): 544-59.

Wyss-Coray, T., E. Masliah, et al. (1997). "Amyloidogenic role of cytokine TGF-beta1 in transgenic mice and in Alzheimer's disease." Nature 389(6651): 603-6.

Xanthoudakis, S., G. Miao, et al. (1992). "Redox activation of Fos-Jun DNA binding activity is mediated by a DNA repair enzyme." Embo J 11(9): 3323-35.

Xu, X., Z. Weaver, et al. (1999). "Centrosome amplification and a defective G2-M cell cycle checkpoint induce genetic instability in BRCA1 exon 11 isoform-deficient cells." Mol Cell 3(3): 389-95.

Yamada, T., K. Miyazaki, et al. (1995). "Selective localization of gelatinase A, an enzyme degrading betaamyloid protein, in white matter microglia and in Schwann cells." Acta Neuropathol (Berl) 89(3): 199203.

Yang, J., Y. Yu, et al. (2003). "Protein kinases and their involvement in the cellular responses to genotoxic stress." Mutat Res 543(1): 31-58.

Yang, J., Z. P. Xu, et al. (2004). "ATM and ATR: sensing DNA damage." World J Gastroenterol 10(2): 155-60.

Yang, L. B., K. Lindholm, et al. (2003). "Elevated beta-secretase expression and enzymatic activity detected in sporadic Alzheimer disease." Nat Med 9(1): 3-4.

Yang, Y. H. and T. Speed (2002). "Design issues for cDNA microarray experiments." Nat Rev Genet 3(8): 579-88. 
Ye, Y., N. Lukinova, et al. (1999). "Neurogenic phenotypes and altered Notch processing in Drosophila Presenilin mutants." Nature 398(6727): 525-9.

You, Z., L. Kong, et al. (2002). "The role of single-stranded DNA and polymerase alpha in establishing the ATR, Hus1 DNA replication checkpoint." J Biol Chem 277(30): 27088-93.

Younkin, S. G. (1995). "Evidence that A beta 42 is the real culprit in Alzheimer's disease." Ann Neurol 37(3): 287-8.

Yu, H., C. A. Saura, et al. (2001). "APP processing and synaptic plasticity in presenilin-1 conditional knockout mice." Neuron 31(5): 713-26.

Zaudig, M. (1992). "A new systematic method of measurement and diagnosis of "mild cognitive impairment" and dementia according to ICD-10 and DSM-III-R criteria." Int Psychogeriatr 4 Suppl 2: 203-19.

Zaudig, M., J. Mittelhammer, et al. (1991). "SIDAM--A structured interview for the diagnosis of dementia of the Alzheimer type, multi-infarct dementia and dementias of other aetiology according to ICD-10 and DSM-III-R." Psychol Med 21(1): 225-36.

Zhong, Q., C. F. Chen, et al. (1999). "Association of BRCA1 with the hRad50-hMre11-p95 complex and the DNA damage response." Science 285(5428): 747-50.

Zhou, B. B. and S. J. Elledge (2000). "The DNA damage response: putting checkpoints in perspective." Nature 408(6811): 433-9.

Zou, L., D. Cortez, et al. (2002). "Regulation of ATR substrate selection by Rad17-dependent loading of Rad9 complexes onto chromatin." Genes Dev 16(2): 198-208. 
ANEXOS 


\section{Hospital das Clínicas - HCFMRP/USP \\ Divisão de Clínica Médica e Geriatria}

Mini-exame do Estado Mental (MEEM)

N/Ref.:

Nome do paciente:

Data de nascimento:

Cidade:

Escolaridade:

\section{OrientaçÃo}

5 ( ) ano - mês - dia do mês - dia da semana - hora aproximada

5 ( ) estado - cidade - bairro - local - andar

\section{REGISTRO}

3 ( ) pente - vaso - laranja

Tentativas:

\section{Atenção e CÁlculo}

5 ( ) seriado descendente de 7: 93, 86, 79, 72, 65 ou soletrar a palavra "mundo" de trás para frente.

\section{EvocaçÃo}

3 ( ) repetir as três palavras dadas para registro.

\section{LINGUAGEM}

9 ( ) - denominar um relógio de pulso e uma caneta

- repetir "nem aqui, nem ali, nem lá"

- atender ao comando 3 estágios: "Pegue o papel com a mão direita, dobre-o ao meio e ponha-o sobre o chão"

- ler e obedecer: FECHE OS OLHOS

- escrever uma frase:

- copiar o desenho

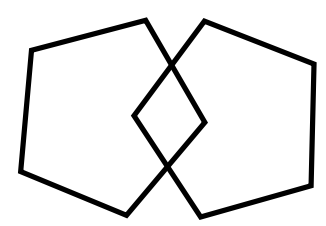

Escore total:

(máx. 30) 


\section{Escala de DEPREssão EM GERIATRIA}

Escolha a melhor resposta de como se na última semana

1. A senhora está satisfeita com a sua vida?

$$
\operatorname{Sim}(\mathrm{N}) \quad \text { Não (D) }
$$

2. A senhora diminuiu a maior parte de suas atividades e interesses?

$$
\operatorname{Sim}(\mathrm{D}) \quad \text { Não }(\mathrm{N})
$$

3. A senhora sente que a vida está vazia?

$$
\text { Sim (D) Não (N) }
$$

4. A senhora geralmente se sente aborrecida?

$$
\operatorname{Sim}(\mathrm{D}) \quad \text { Não }(\mathrm{N})
$$

5. A senhora se sente animada a maior parte do tempo?

$$
\operatorname{Sim}(\mathrm{N}) \quad \text { Não (D) }
$$

6. A senhora tem medo que algo ruim possa the acontecer?

$$
\operatorname{Sim}(\mathrm{D}) \quad \text { Não (N) }
$$

7. A senhora se sente feliz a maior parte do tempo?

$$
\text { Sim (N) Não (D) }
$$

8. A senhora se sente freqüentemente desamparada?

$$
\operatorname{Sim}(\mathrm{D}) \quad \text { Não }(\mathrm{N})
$$

9. A senhora prefere ficar em casa a sair e fazer coisas novas?

$$
\text { Sim (D) Não (N) }
$$

10. A senhora acha que tem mais problemas de memória que a maioria das pessoas?

$$
\operatorname{Sim}(\mathrm{D}) \quad \text { Não }(\mathrm{N})
$$

11. A senhora acha que é bom estar viva?

$$
\operatorname{Sim}(\mathrm{N}) \quad \text { Não (D) }
$$

12. A senhora se sente inútil ou incapaz do jeito que está agora?

$$
\text { Sim (D) Não (N) }
$$

13. A senhora se sente cheia de energia?

$$
\text { Sim (N) Não (D) }
$$

14. A senhora se sente desesperançosa?

$$
\text { Sim (D) Não (N) }
$$

15. A senhora acha que a maioria das pessoas é melhor que a senhora?

$$
\text { Sim (D) Não (N) }
$$

$\mathbf{D}=$ deprimida $\quad \mathbf{N}=$ normal

Total (contar as respostas D): 


\section{Hospital das Clínicas - HCFMRP/USP \\ Setor de Geriatria}

Formulário de triagem dos pacientes

N/Ref.:

Nome do paciente:

Data de nascimento:

Cidade:

Escolaridade:

Nome do acompanhante:

Já sofreu algum acidente vascular cerebral (derrame)? $\square \operatorname{Sim} \square$ Não

O paciente é diabético? $\square$ Sim $\square$ Não

Fumante? $\square \operatorname{Sim} \quad \square$ Não (mínimo 6 meses)

1. Orientação temporal (0-5): ANO - MÊS - DIA - DIA DA SEMANA - HORA

2. Orientação espacial (0-5): ESTADO - RUA - CIDADE - LOCAL - ANDAR

3. Registro (0-3): nomear: PENTE - RUA - CANETA

4. Cálculo- tirar 7 (0-5): 100-93-86-79-65

5. Evocação (0-3): três palavras anteriores: PENTE - VASO - LARANJA

6. Linguagem 1 (0-2): nomear um RELÓGIO e uma CANETA

7. Linguagem 2 (0-1): repetir: NEM AQUI, NEM ALI, NEM LÁ

8. Linguagem $3(0-3)$ : siga o comando: Pegue o papel com a mão direita, dobre-o ao meio, coloque-o em cima da mesa.

9. Linguagem 4 (0-1): ler e obedecer: FECHE OS OLHOS

10. Linguagem $5(0-1)$ : escreva uma frase completa

11. Linguagem 6 (0-1): copiar o desenho.

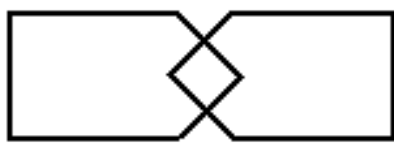

TOTAL

MEEM:

CDR:

Relógio:

Grau de Alzheimer: $\square$ Leve $\square$ Moderado $\square$ Grave

Medicamentos: $\square$ Rivastigmina $\square$ Donepezil $\square$ Galantamina $\square$ Memantina Outros:

Observações: 


\title{
Hospital das Clínicas da Faculdade de Medicina de Ribeirão Preto \\ UNIVERSIDADE DE SÃo PAULO
}

Campus Universitário Monte Alegre - Fone: 3633-1000 - Fax: 3633-1144

CEP 14048-900 Ribeirão Preto São Paulo

\begin{abstract}
Nome da pesquisa: AVALIAÇÃO DA EXPRESSÃO DE GENES PROCESSADORES DE DANOS OXIDATIVOS EM PACIENTES COM ALZHEIMER.

Pesquisador responsável: Douglas Vinicius Nogueira Perez de Oliveira

Endereço para contato: Av. Bandeirantes, 3900; CEP: 14049-900

Laboratório de Citogenética e Mutagênese, Bloco G

Departamento de Genética - Faculdade de Medicina de Ribeirão Preto Universidade de São Paulo (FMRP/USP).
\end{abstract}

Telefone : (16) 3602-3082

\section{Termo de Consentimento livre e esclarecido - Controles sadios}

Eu, Douglas Vinicius Nogueira Perez de Oliveira, pós-graduando em nível de mestrado, do Departamento de Genética, da Faculdade de Medicina de Ribeirão Preto, da Universidade de São Paulo, estou realizando um estudo sobre a doença de Alzheimer. Trata-se de uma doença neurodegenerativa, que afeta a memória dos portadores, levando a um estado de total dependência da família. Este estudo tem como finalidade a procura de genes que possam contribuir, ou ser responsáveis pelo desenvolvimento da doença de Alzheimer. Dessa forma, esperamos obter resultados que possam contribuir para o melhor entendimento da doença, embora o presente estudo não deva beneficiar diretamente os participantes.

Para a realização desta pesquisa, é necessária a participação de pessoas que não apresentam a doença de Alzheimer, para podermos comparar os resultados entre os grupos sadios (controle) e doentes (com a doença de Alzheimer). Sendo este o termo de consentimento livre e esclarecido dirigido aos voluntários sadios, o pesquisador declara que não prevê qualquer benefício direto ao voluntário com relação à sua participação no estudo.

Assim, caso concorde em participar da realização da nossa pesquisa, faz-se necessária a coleta de $20 \mathrm{~mL}$ de sangue periférico (o equivalente a uma seringa de sangue), por punção venosa, que será feita por um profissional habilitado e altamente capacitado nessa atividade. Esclareço ao voluntário os seguintes aspectos:

a. Não haverá nenhum risco em participar da pesquisa e o voluntário terá a garantia de receber a resposta a qualquer pergunta ou esclarecimento a qualquer dúvida acerca dos procedimentos, riscos, benefícios e outros relacionados com a pesquisa; 
b. Será dada a liberdade de retirar o seu consentimento a qualquer momento sem que isso traga prejuízo algum ou qualquer tipo de constrangimento;

c. Será garantida a segurança de que o voluntário não será identificado e que será mantido o caráter confidencial da informação relacionada com a sua privacidade;

d. Temos o compromisso de proporcionar informações atualizadas durante o estudo, ainda que esta possa influenciar a vontade do voluntário de continuar autorizando a sua participação;

e. Todos os exames de sangue serão coletados com total responsabilidade e custo dos pesquisadores. A coleta de sangue será feita com material descartável, sendo necessária apenas uma punção da veia do braço, o que pode, de fato, ser um procedimento desconfortável, mas apenas pela "picada" com a agulha;

f. Pelo fato desta pesquisa não impor risco à saúde dos voluntários, não haverá a necessidade de conceder remuneração ou ressarcimento aos participantes, mas em casos excepcionais, caso o voluntário se sinta lesado com o procedimento da coleta de sangue, este poderá requerer os seus direitos de acordo com as leis vigentes no país.

Para esclarecer quaisquer dúvidas, telefonar para (16) 3602-3082 ou 3602-3827 e falar com Douglas V.N.P. Oliveira (pós-graduando) ou com a Prof. Elza T. Sakamoto Hojo (orientadora do aluno). Endereço: Departamento de Genética, bloco G, Faculdade de Medicina de Ribeirão Preto, Universidade de São Paulo; Av Bandeirantes 3900, 14040-901 Ribeirão Preto, SP.

Douglas V.N.P. Oliveira

$\mathrm{Eu}$, portador do R.G. abaixo assinado, tendo recebido as informações supra citadas, ciente dos meus direitos acima relacionados e diante dos esclarecimentos prestados, concordo em participar da pesquisa na qualidade de voluntário.

Ribeirão Preto, de de 20 


\title{
Hospital das Clínicas da Faculdade de Medicina de Ribeirão Preto \\ UNIVERSIDADE dE SÃo PAULO
}

Campus Universitário Monte Alegre - Fone: 3633-1000 - Fax: 3633-1144

CEP 14048-900 Ribeirão Preto São Paulo

\begin{abstract}
Nome da pesquisa: AVALIAÇÃO DA EXPRESSÃO DE GENES PROCESSADORES DE DANOS OXIDATIVOS EM PACIENTES COM ALZHEIMER.

Pesquisador responsável: Douglas Vinicius Nogueira Perez de Oliveira

Endereço para contato: Av. Bandeirantes, 3900; CEP: 14049-900

Laboratório de Citogenética e Mutagênese, Bloco G

Departamento de Genética - Faculdade de Medicina de Ribeirão Preto Universidade de São Paulo (FMRP/USP).
\end{abstract}

Telefone : (16) 3602-3082

\section{Termo de Consentimento livre e esclarecido - Pacientes}

Eu, Douglas Vinicius Nogueira Perez de Oliveira, pós-graduando em nível de mestrado, do Departamento de Genética, da Faculdade de Medicina de Ribeirão Preto, da Universidade de São Paulo, estou realizando um estudo sobre a doença de Alzheimer. Trata-se de uma doença neurodegenerativa, que afeta a memória dos portadores, levando a um estado de total dependência da família. Este estudo tem como finalidade a procura de genes que possam contribuir, ou ser responsáveis pelo desenvolvimento da doença de Alzheimer. Dessa forma, esperamos obter resultados que possam contribuir para o melhor entendimento da doença, embora o presente estudo não deva beneficiar diretamente os participantes.

Assim, para a realização da nossa pesquisa, faz-se necessária a coleta de $20 \mathrm{~mL}$ de sangue periférico (o equivalente a uma seringa de sangue), por punção venosa, que será feita somente quando o paciente comparecer ao ambulatório para os exames de seguimento solicitados pelo médico responsável. Desta forma, não será feita nenhuma colheita de sangue em outra ocasião. Esclareço ao paciente e ao responsável pelo mesmo, os seguintes aspectos:

g. Não haverá nenhum risco em participar da pesquisa e o voluntário terá a garantia de receber a resposta a qualquer pergunta ou esclarecimento a qualquer dúvida acerca dos procedimentos, riscos, benefícios e outros relacionados com a pesquisa;

h. Será dada a liberdade de retirar o seu consentimento a qualquer momento sem que isso traga prejuízo algum;

i. Será garantida a segurança de que não serei identificado e que será mantido o caráter confidencial da informação relacionada com a sua privacidade; 
j. Temos o compromisso de proporcionar informações atualizadas durante o estudo, ainda que estas possam influenciar a sua vontade de continuar autorizando a participação;

k. Todos os exames de sangue serão coletados com total responsabilidade e custo dos pesquisadores. A coleta de sangue será feita com material descartável, sendo necessária apenas uma punção da veia do braço, o que pode, de fato, ser um procedimento desconfortável, mas apenas pela "picada" com a agulha;

I. Não ocorrerão prejuízos no tratamento clínico instituído neste ambulatório, pois não serão substituídas ou modificadas quaisquer medicações por conta deste estudo;

m. Pelo fato desta pesquisa não impor risco à saúde dos pacientes, não haverá a necessidade de conceder remuneração ou ressarcimento aos participantes, mas em casos excepcionais, caso o paciente se sinta lesado com o procedimento da coleta de sangue, este poderá requerer os seus direitos de acordo com as leis vigentes no país.

Para esclarecer quaisquer dúvidas, telefonar para (16) 3602-3082 ou 3602-3827 e falar com Douglas V.N.P. Oliveira (pós-graduando) ou com a Prof. Elza T. Sakamoto Hojo (orientadora do aluno). Endereço: Departamento de Genética, bloco G, Faculdade de Medicina de Ribeirão Preto, Universidade de São Paulo; Av Bandeirantes 3900, 14040-901 Ribeirão Preto, SP.

Douglas V.N.P. Oliveira

$\mathrm{Eu}$, portador do R.G. abaixo assinado, tendo recebido as informações supra citadas, ciente dos meus direitos acima relacionados e diante dos esclarecimentos prestados, concordo em participar da pesquisa na qualidade de voluntário.

Ribeirão Preto, de de 20 